\title{
Enantioselective Synthesis of P-Stereogenic
}

\section{Benzophospholanes via Palladium-Catalyzed}

\section{Intramolecular Cyclization}

Tim J. Brunker, ${ }^{a}$ Brian J. Anderson, ${ }^{a}$ Natalia F. Blank, ${ }^{a}$ David S. Glueck, ${ }^{a}$ and Arnold L. Rheingold ${ }^{b}$

a6128 Burke Laboratory, Department of Chemistry, Dartmouth College, Hanover, New Hampshire, $03755^{\text {b }}$ Department of Chemistry, University of California, San Diego, La Jolla, California, 92093

\section{Supporting Information}

1. Experimental Section

2. X-ray Crystallographic Details

3. NMR Spectra

General Experimental Details. Unless otherwise noted, all reactions and manipulations were performed in dry glassware under a nitrogen atmosphere at $20{ }^{\circ} \mathrm{C}$ in a dry box or using standard Schlenk techniques. Petroleum ether (bp 38-53 ${ }^{\circ} \mathrm{C}$ ), $\mathrm{CH}_{2} \mathrm{Cl}_{2}$, ether, THF, and toluene were dried over alumina columns similar to those described by Grubbs. ${ }^{1}$ NMR spectra were recorded using Varian 300 or $500 \mathrm{MHz}$ spectrometers. ${ }^{1} \mathrm{H}$ or ${ }^{13} \mathrm{C}$ NMR chemical shifts are reported vs $\mathrm{Me}_{4} \mathrm{Si}$ and were determined by reference to the residual ${ }^{1} \mathrm{H}$ or ${ }^{13} \mathrm{C}$ solvent peaks. ${ }^{31} \mathrm{P}$ NMR chemical shifts are reported vs $\mathrm{H}_{3} \mathrm{PO}_{4}(85 \%)$ used as an external reference. Coupling constants are reported in $\mathrm{Hz}$, as absolute values unless noted otherwise. Unless indicated, peaks in NMR spectra are singlets. 
Instead of the expected quartet resonances ${ }^{2}$ in the ${ }^{31} \mathrm{P}$ NMR spectra of the phosphine-boranes, poorly resolved multiplets were often observed; in some cases the signal was an apparent doublet. Elemental analyses were provided by Schwarzkopf Microanalytical Laboratory or Quantitative Technologies Inc. Mass spectra were recorded at the University of Illinois, Urbana-Champaign (http://www.scs.uiuc.edu/ msweb).

The following compounds were prepared by literature methods: $o-\mathrm{IC}_{6} \mathrm{H}_{4} \mathrm{CH}_{2} \mathrm{CH}_{2} \mathrm{I}^{3}$ $\mathrm{PH}_{2} \mathrm{Ph}\left(\mathrm{BH}_{3}\right),{ }^{4} \mathrm{PH}_{2} \mathrm{Men}\left(\mathrm{BH}_{3}\right),{ }^{5} \mathrm{Pd}($ diphos $*)($ stilbene $)$ and $\mathrm{Pd}($ Et-FerroTANE $)(\mathrm{Ph})(\mathrm{I})$ catalyst precursors, ${ }^{6} \mathrm{Pd}(\mathrm{dba})_{2},{ }^{7}$ and $\left.\mathrm{Pd}\left((\mathrm{S})-\mathrm{Me}_{2} \mathrm{NCH}(\mathrm{Me}) \mathrm{C}_{6} \mathrm{H}_{4}\right)(\mu-\mathrm{Cl})\right)_{2}{ }^{8}$

\section{$o-\mathrm{IC}_{6} \mathrm{H}_{4} \mathrm{CH}_{2} \mathrm{CH}_{2} \mathrm{PH}(\mathrm{Ph})\left(\mathrm{BH}_{3}\right)(8 \mathrm{a})$}

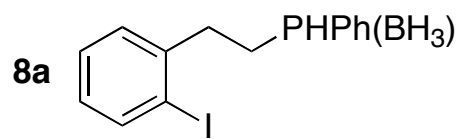

$\mathrm{PH}_{2} \mathrm{Ph}\left(\mathrm{BH}_{3}\right)(1.09 \mathrm{~g}, 8.55 \mathrm{mmol})$ was dissolved in THF $(10 \mathrm{~mL})$ and added slowly to a stirred suspension of $\mathrm{NaH}(205 \mathrm{mg}, 8.55 \mathrm{mmol})$ in THF $(20 \mathrm{~mL})$ at $0{ }^{\circ} \mathrm{C} . \mathrm{H}_{2}$ evolution was observed immediately and by the end of the addition a purple-grey solution formed. The solution was stirred at $0{ }^{\circ} \mathrm{C}$ for a further $45 \mathrm{~min}$ and then a solution of 2-(2'-iodophenyl)ethyl iodide $(3.06 \mathrm{~g}, 8.55$ $\mathrm{mmol})$ in THF (30 mL) was added dropwise over $10 \mathrm{~min}$. The cooling bath was then removed and the reaction mixture was stirred for $18 \mathrm{~h}$ at room temperature. The pale green mixture was quenched by addition of $\mathrm{H}_{2} \mathrm{O}(50 \mathrm{~mL})$, transferred to a separating funnel and $\mathrm{Et}_{2} \mathrm{O}(60 \mathrm{~mL})$ was added. The organic layer was then separated and the aqueous layer was washed with additional $\mathrm{Et}_{2} \mathrm{O}(60 \mathrm{~mL})$. The organic extracts were washed with brine $(2 \times 50 \mathrm{~mL})$ and dried over $\mathrm{MgSO}_{4}$. The solution was then filtered and all solvent removed in vacuo to give a pale orange oil. Phosphine-borane $\mathbf{8 a}\left(\mathrm{R}_{\mathrm{f}}=\right.$ $0.26,10 \%$ ethyl acetate/hexane) was separated from a small amount of iodide starting material by dry-column flash chromatography on silica. A small amount of unreacted 2-(2'-iodophenyl)ethyl iodide was eluted with hexane. Elution with $10 \%$ ethyl acetate/hexane yielded, after removal of solvent in vacuo, $2.33 \mathrm{~g}(6.58 \mathrm{mmol}, 77 \%)$ of the product as a colorless cloudy oil, shown to be essentially pure by NMR spectroscopy. 
Anal calcd for $\mathrm{C}_{14} \mathrm{H}_{17}$ BIP: C, 47.50; H, 4.84. Found: C, 47.58; H, 4.99. HRMS calcd. for $\mathrm{C}_{14} \mathrm{H}_{16} \mathrm{BIP}(\mathrm{M}-\mathrm{H})^{+}: \mathrm{m} / \mathrm{z}$ 353.0127. Found: $\mathrm{m} / \mathrm{z}$ 353.0143. ${ }^{31} \mathrm{P}\left\{{ }^{1} \mathrm{H}\right\}$ NMR $\left(\mathrm{CDCl}_{3}\right): \delta-3.3$ (br d, $\mathrm{J}=55) .{ }^{1} \mathrm{H} \mathrm{NMR}\left(\mathrm{CDCl}_{3}\right): \delta$ 7.82-7.71 (m, 3H, Ar), 7.58-7.46 (m, 3H, Ar), 7.31-7.20 (m, 2H, Ar), 6.94-6.88 (m, 1H, Ar), 5.57 (d of m, $\left.{ }^{1} \mathrm{~J}_{\mathrm{PH}}=340,1 \mathrm{H}, \mathrm{PH}\right), 3.05-2.85\left(\mathrm{~m}, 2 \mathrm{H}, \mathrm{CH}_{2}\right.$ ), 2.37-2.16 (m, 2H, $\left.\mathrm{CH}_{2}\right), 1.5-0.3$ (v. br q, 3H, $\left.\mathrm{BH}_{3}\right) .{ }^{13} \mathrm{C}\left\{{ }^{1} \mathrm{H}\right\}$ NMR $\left(\mathrm{CDCl}_{3}\right): \delta 143.1$ (d, J = 13, Ar q), 139.9 (Ar), 133.1 (d, J = 9, Ar), 132.0 (d, J = 3, Ar), 129.6 (Ar), 129.3 (d, J = 10, Ar), 128.9 (Ar), 128.7 (Ar), $125.2(\mathrm{~d}, \mathrm{~J}=56, \operatorname{Ar} \mathrm{q}), 100.0(\mathrm{Ar}-\mathrm{I}), 35.4\left(\mathrm{~d}, \mathrm{~J}=2, \mathrm{CH}_{2}\right), 24.2\left(\mathrm{~d}, \mathrm{~J}=34, \mathrm{CH}_{2}\right)$.

\section{$o-\mathrm{IC}_{6} \mathrm{H}_{4} \mathrm{CH}_{2} \mathrm{CH}_{2} \mathrm{PH}(\mathrm{Cy})\left(\mathrm{BH}_{3}\right)(8 \mathrm{~b})$}

8b<smiles>CCCCCCCCCc1ccccc1I</smiles>

Cyclohexylphosphine $(0.368 \mathrm{~g}, 3.17 \mathrm{mmol})$ was dissolved in THF $(10 \mathrm{~mL})$ and cooled to $0{ }^{\circ} \mathrm{C}$. $\mathrm{BH}_{3}-\mathrm{SMe}_{2}(1.58 \mathrm{~mL}, 3.17 \mathrm{mmol}, 2.0 \mathrm{M}$ solution in THF) was then added by syringe and the mixture was stirred at $0{ }^{\circ} \mathrm{C}$ for $2 \mathrm{~h}$. The solution was then cooled to $-78{ }^{\circ} \mathrm{C}$ and $s$-BuLi $(2.26 \mathrm{~mL}$, $3.17 \mathrm{mmol}, 1.4 \mathrm{M}$ solution in cyclohexane) was added by syringe. After $40 \mathrm{~min}$ at $-78{ }^{\circ} \mathrm{C}$ the solution was warmed to room temperature and stirred for an additional $20 \mathrm{~min}$. The solution was then re-cooled to $-78{ }^{\circ} \mathrm{C}$ and a solution of 2-(2'-iodophenyl)ethyl iodide (1.13 $\left.\mathrm{g}, 3.17 \mathrm{mmol}\right)$ in THF (10 mL) was added dropwise. The reaction mixture was allowed to warm up slowly and stir overnight. The reaction mixture was then quenched by the addition of $\mathrm{H}_{2} \mathrm{O}(30 \mathrm{~mL})$ and $\mathrm{Et}_{2} \mathrm{O}(25$ $\mathrm{mL})$. The layers were separated, and the aqueous layer was extracted with $\mathrm{Et}_{2} \mathrm{O}(2 \times 25 \mathrm{~mL})$. The combined organic extracts were washed with brine $(30 \mathrm{~mL})$ and dried over $\mathrm{MgSO}_{4}$. The solution was filtered and all volatiles removed in vacuo to give a colorless oil which was purified by gradient column chromatography on silica. Elution with hexane first gave unreacted 2-(2'-iodophenyl)ethyl iodide $\left(73 \mathrm{mg}\right.$ ). Elution with $10 \%$ ethyl acetate/hexanes (product $\mathrm{R}_{\mathrm{f}}=0.46$ ) then yielded $780 \mathrm{mg}$ ( $2.17 \mathrm{mmol}, 68 \%$ yield based on starting phosphine) of pale yellow viscous oil shown to be pure product by NMR spectroscopy.

HRMS m/z calcd. for $\mathrm{C}_{14} \mathrm{H}_{22} \mathrm{BIP}(\mathrm{M}-\mathrm{H})^{+}: \mathrm{m} / \mathrm{z}$ 359.0597. Found: $\mathrm{m} / \mathrm{z} 359.0611 .{ }^{31} \mathrm{P}\left\{{ }^{1} \mathrm{H}\right\}$ $\operatorname{NMR}\left(\mathrm{C}_{6} \mathrm{D}_{6}\right): \delta 5.2(\mathrm{brd}, \mathrm{J}=57) .{ }^{1} \mathrm{H}$ NMR $\left(\mathrm{C}_{6} \mathrm{D}_{6}\right): \delta 7.60(\mathrm{dd}, \mathrm{J}=8,1,1 \mathrm{H}, \mathrm{Ar}), 6.92-6.84(\mathrm{~m}$, 
2H, Ar), $6.49(\mathrm{~m}, 1 \mathrm{H}, \mathrm{Ar}), 4.00\left(\mathrm{~d}\right.$ of $\left.\mathrm{m},{ }^{1} \mathrm{~J}_{\mathrm{PH}}=351, \mathrm{PH}\right), 2.94-2.68\left(\mathrm{~m}, 2 \mathrm{H}, \mathrm{CH}_{2}\right), 1.75-1.52(\mathrm{~m}$, 2H), 1.49-1.39 (m, 5H), 1.37-1.26 (m, 1H), 1.20-1.02 (m, 2H), 1.00-0.85 (m, 3H), 1.8-0.8 (br q, $\left.3 \mathrm{H}, \mathrm{BH}_{3}\right) .{ }^{13} \mathrm{C}\left\{{ }^{1} \mathrm{H}\right\} \operatorname{NMR}\left(\mathrm{C}_{6} \mathrm{D}_{6}\right): \delta 143.9(\mathrm{~d}, \mathrm{~J}=12, \mathrm{Ar} q), 139.8$ (Ar), 129.8 (Ar), 128.8 (Ar), 128.5 (Ar), 100.2 (Ar q), $35.9\left(\mathrm{CH}_{2}\right), 30.6(\mathrm{~d}, \mathrm{~J}=35, \mathrm{CH}), 28.5\left(\mathrm{~d}, \mathrm{~J}=2, \mathrm{CH}_{2}\right), 27.8\left(\mathrm{CH}_{2}\right), 26.5$ $\left(\mathrm{d}, \mathrm{J}=2, \mathrm{CH}_{2}\right), 26.4\left(\mathrm{~d}, \mathrm{~J}=3, \mathrm{CH}_{2}\right), 25.8\left(\mathrm{~d}, \mathrm{~J}=1, \mathrm{CH}_{2}\right), 19.3\left(\mathrm{~d}, \mathrm{~J}=31, \mathrm{CH}_{2}\right)$.

\section{$o-\mathrm{IC}_{6} \mathrm{H}_{4} \mathrm{CH}_{2} \mathrm{CH}_{2} \mathrm{PH}(\mathrm{Men})\left(\mathrm{BH}_{3}\right)(8 \mathrm{c})$}

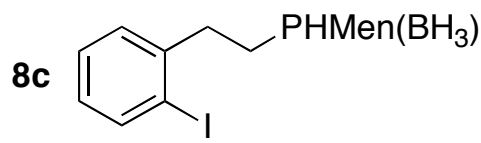

A degassed solution of $\mathrm{PH}_{2}(\mathrm{Men})\left(\mathrm{BH}_{3}\right)(0.455 \mathrm{~g}, 2.44 \mathrm{mmol})$ in dry THF $(20 \mathrm{~mL})$ was cooled to $-78{ }^{\circ} \mathrm{C}$ at which temperature sec-BuLi $(2 \mathrm{~mL}, 2.8 \mathrm{mmol}, 1.4 \mathrm{M}$ solution in cyclohexanes, 1.2 equiv) was added via syringe. The reaction mixture was stirred at this temperature for 40 min and then was warmed up and stirred for $30 \mathrm{~min}$ at room temperature to ensure the completion of the reaction. The mixture was cooled again to $-78^{\circ} \mathrm{C}$ and $2-\left(2^{\prime}\right.$-iodophenyl)ethyl iodide (874 $\mathrm{mg}, 2.44$ mmol) was added dropwise as a solution in THF $(10 \mathrm{~mL})$. The mixture was stirred overnight while warming up to room temperature and quenched with water. The mixture was extracted with ether $(3 \times 25 \mathrm{~mL})$. The combined organic layers were washed with water $(3 \times 50 \mathrm{~mL})$ and a saturated solution of $\mathrm{NH}_{4} \mathrm{Cl}(50 \mathrm{~mL})$ and dried over $\mathrm{MgSO}_{4}$. The product was purified by column chromatography. Small amounts of unreacted 2-(2'-iodophenyl)ethyl iodide and $\mathrm{PH}_{2}(\mathrm{Men})\left(\mathrm{BH}_{3}\right)$ as well as $\mathrm{PH}_{2}$ (Men) (deprotected during the reaction) were eluted with hexane. Elution with 2\% ethyl acetate/hexanes yielded, after removal of solvent in vacuo, $438 \mathrm{mg}$ (43\%) of the product as a colorless oil, shown to be an essentially pure 1:1 mixture of diastereomers by NMR spectroscopy.

Anal. calcd for $\mathrm{C}_{18} \mathrm{H}_{31}$ BIP: C, 51.95; H, 7.51. Found: C, 52.37; H, 7.39. HRMS calcd for $\mathrm{C}_{18} \mathrm{H}_{28} \mathrm{BIP}(\mathrm{M}-3 \mathrm{H})^{+}: \mathrm{m} / \mathrm{z}$ 413.1067. Found: $\mathrm{m} / \mathrm{z}$ 413.1062. Note: we observed similar mass spectroscopic behavior (loss of $3 \mathrm{H}$ ) with other menthylphosphine-boranes. ${ }^{5} \quad{ }^{31} \mathrm{P}\left\{{ }^{1} \mathrm{H}\right\} \quad \mathrm{NMR}$ (toluene- $\mathrm{d}_{8}$ ): $\delta-4.3$ (br m), -6.3 (br m). ${ }^{1} \mathrm{H}$ NMR (toluene- $\left.\mathrm{d}_{8}\right): \delta 7.55(1 \mathrm{H}, \mathrm{CH}, \mathrm{Ar}), 7.53(1 \mathrm{H}, \mathrm{CH}$, Ar), $6.89(\mathrm{~d}, \mathrm{~J}=7.5,1 \mathrm{H}, \mathrm{CH}, \mathrm{Ar}), 6.87(1 \mathrm{H}, \mathrm{CH}, \mathrm{Ar}), 6.86(1 \mathrm{H}, \mathrm{CH}, \mathrm{Ar}), 6.78-6.76$ (m, 1H, CH, Ar), 6.52-6.44 (m, 2H, Ar), $4.43(\mathrm{dm}, \mathrm{J}=350,1 \mathrm{H}, \mathrm{P}-\mathrm{H}), 4.36$ (br dm, J = 355, 1H, P-H), 3.00-2.90 
(m, 1H), 2.81-2.60 (m, 2H), 1.98-1.76 (m, 3H), 1.76-1.42 (m, $11 \mathrm{H}), 1.32-1.12(\mathrm{~m}, 7 \mathrm{H}), 0.94-0.82$ $(\mathrm{m}, 10 \mathrm{H}), 0.79(\mathrm{~d}, \mathrm{~J}=7,3 \mathrm{H}, \mathrm{Me}), 0.77(\mathrm{~d}, \mathrm{~J}=7,3 \mathrm{H}, \mathrm{Me}$, overlapping with the previous signal), $0.62(\mathrm{~d}, \mathrm{~J}=7,3 \mathrm{H}, \mathrm{Me}), 0.54(\mathrm{~d}, \mathrm{~J}=7,3 \mathrm{H}, \mathrm{Me}) .{ }^{13} \mathrm{C}\left\{{ }^{1} \mathrm{H}\right\}$ NMR (toluene-d $\left.\mathrm{d}_{8}\right): \delta 143.8(\mathrm{~d}, \mathrm{~J}=10$, $\mathrm{CH}), 143.7$ (d, J = 10, CH, overlapping with previous signal), $139.9(\mathrm{CH}), 137.4$ (quat), 129.9 $(\mathrm{CH}), 129.6(\mathrm{CH}), 129.1(\mathrm{CH}), 128.7(\mathrm{~d}, \mathrm{~J}=4, \mathrm{CH}), 128.4(\mathrm{~d}, \mathrm{~J}=5, \mathrm{CH}), 128.2(\mathrm{CH}), 100.2(\mathrm{Ar}-$ I), 100.1 (Ar-I), $43.3(\mathrm{~d}, \mathrm{~J}=3, \mathrm{CH}), 43.1(\mathrm{CH}), 36.8\left(\mathrm{~d}, \mathrm{~J}=23, \mathrm{CH}_{2}\right), 36.6\left(\mathrm{~d}, \mathrm{~J}=22, \mathrm{CH}_{2}\right), 34.7$ $\left(\mathrm{CH}_{2}\right), 34.5\left(\mathrm{~d}, \mathrm{~J}=11, \mathrm{CH}_{2}\right), 34.3(\mathrm{~d}, \mathrm{~J}=31, \mathrm{CH}), 33.5(\mathrm{~d}, \mathrm{~J}=13, \mathrm{CH}), 32.6(\mathrm{~d}, \mathrm{~J}=32, \mathrm{CH}), 31.9$ $\left(\mathrm{CH}_{2}\right), 29.4\left(\mathrm{CH}_{2}\right), 28.4(\mathrm{~d}, \mathrm{~J}=10, \mathrm{CH}), 27.9(\mathrm{~d}, \mathrm{~J}=5, \mathrm{CH}), 24.7\left(\mathrm{~d}, \mathrm{~J}=10, \mathrm{CH}_{2}\right), 24.6(\mathrm{~d}, \mathrm{~J}=11$, $\left.\mathrm{CH}_{2}\right), 23.0\left(\mathrm{CH}_{2}\right), 22.4(\mathrm{Me}), 22.3(\mathrm{Me}), 21.3(\mathrm{Me}), 21.2(\mathrm{Me}), 19.8\left(\mathrm{~d}, \mathrm{~J}=4, \mathrm{CH}_{2}\right), 19.6\left(\mathrm{CH}_{2}\right)$, $15.1(\mathrm{Me}), 14.3(\mathrm{Me})$.

$o-\mathrm{IC}_{6} \mathrm{H}_{4} \mathrm{CH}_{2} \mathrm{CH}_{2} \mathrm{PH}(\mathrm{Ph})(9 \mathrm{a})$

9a<smiles>Ic1ccccc1CCPc1ccccc1</smiles>

(2-(2'-iodophenyl)ethyl)phenylphosphine-borane (8a, $0.22 \mathrm{~g}, 0.63 \mathrm{mmol})$ and DABCO (84 $\mathrm{mg}$, $0.75 \mathrm{mmol}$ ) were dissolved in benzene $(4 \mathrm{~mL})$ under $\mathrm{N}_{2}$ and stirred at $50{ }^{\circ} \mathrm{C}$ for $1 \mathrm{~h}$. The solvent was then removed in vacuo and the residue was dissolved in petroleum ether $(5 \mathrm{~mL})$ and filtered. The filtrate was pumped down to yield a sticky oil which was then redissolved in petroleum ether (2 $\mathrm{mL})$ and passed through a thick plug of silica eluting with petroleum ether $(15 \mathrm{~mL})$. The solvent was removed in vacuo to yield (2-(2'-iodophenyl)ethyl)phenylphosphine 9a (175 mg, $0.51 \mathrm{mmol}$, $81 \%$ yield) as a colorless mobile oil shown to be essentially pure by NMR spectroscopy. Oxidation of this air-sensitive phosphine was observed by both elemental analysis and mass spectroscopy. Satisfactory elemental analysis of a derivative, the phosphonium salt $\mathbf{9 a} \cdot \mathbf{H B} \mathbf{F}_{\mathbf{4}}$ is reported below.

Anal. Calcd for $\mathrm{C}_{14} \mathrm{H}_{14} \mathrm{IP}$ : C, 49.44; H, 4.15. Anal. Calcd for $\mathrm{C}_{14} \mathrm{H}_{14} \mathrm{IOP}$ : C, 47.21; H, 3.96. Found: C, 47.51; H, 3.87. HRMS calcd for $\mathrm{C}_{14} \mathrm{H}_{15} \mathrm{IOP}(\mathrm{MOH})^{+}: \mathrm{m} / \mathrm{z}$ 356.9905. Found: $\mathrm{m} / \mathrm{z}$ 356.9922. ${ }^{31} \mathrm{P}\left\{{ }^{1} \mathrm{H}\right\} \operatorname{NMR}\left(\mathrm{C}_{6} \mathrm{D}_{6}\right): \delta-50.5 .{ }^{1} \mathrm{H}$ NMR $\left(\mathrm{C}_{6} \mathrm{D}_{6}\right): \delta 7.61(\mathrm{dd}, \mathrm{J}=8,1,1 \mathrm{H}, \mathrm{Ar}), 7.39$ 7.35 (m, 2H, Ar), 7.09-7.05 (m, 3H, Ar), $6.86(\mathrm{td}, \mathrm{J}=8,1,1 \mathrm{H}, \mathrm{Ar}), 6.73$ (dd, J = 8, 2, 1H, Ar), 6.45 $(\mathrm{td}, \mathrm{J}=8,2,1 \mathrm{H}, \mathrm{Ar}), 4.13\left(\mathrm{ddd},{ }^{1} \mathrm{~J}_{\mathrm{PH}}=206,{ }^{3} \mathrm{~J}_{\mathrm{HH}}=8,6,1 \mathrm{H}, \mathrm{PH}\right), 2.78-2.64\left(\mathrm{~m}, 2 \mathrm{H}, \mathrm{CH}_{2}\right), 1.94-1.78$ 
$\left(\mathrm{m}, 2 \mathrm{H}, \mathrm{CH}_{2}\right) .{ }^{13} \mathrm{C}\left\{{ }^{1} \mathrm{H}\right\} \operatorname{NMR}\left(\mathrm{C}_{6} \mathrm{D}_{6}\right): \delta 145.1$ (d, J = 8, Ar q), 139.7 (Ar), 135.6 (d, J = 12, Ar q), $134.1(\mathrm{~d}, \mathrm{~J}=16, \operatorname{Ar}), 129.5$ (Ar), 128.6 (d, J = 6, Ar), 128.4 (Ar), 128.3 (Ar), 128.0 (Ar, obscured by $\mathrm{C}_{6} \mathrm{D}_{6}$ peaks), $100.4(\mathrm{Ar} q), 40.1\left(\mathrm{~d}, \mathrm{~J}=8, \mathrm{CH}_{2}\right), 24.2\left(\mathrm{~d}, \mathrm{~J}=15, \mathrm{CH}_{2}\right)$.

\section{(2-(2'-iodophenyl)ethyl)phenylphosphonium tetrafluoroborate $\left(9 \mathbf{a}^{\prime} \mathbf{H B F}_{4}\right)$}

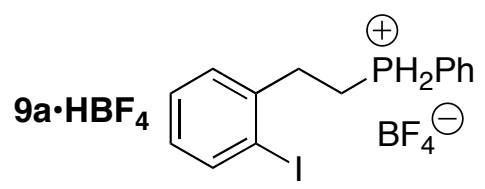

(2-(2'-iodophenyl)ethyl)phenylphosphine (9a, $80 \mathrm{mg}, 0.24 \mathrm{mmol})$ was dissolved in $\mathrm{Et}_{2} \mathrm{O}(1 \mathrm{~mL})$ and added dropwise to a solution of $\mathrm{HBF}_{4} \cdot \mathrm{OMe}_{2}(35 \mathrm{mg}, 0.26 \mathrm{mmol})$ in $\mathrm{Et}_{2} \mathrm{O}(1 \mathrm{~mL})$. A white precipitate immediately formed. The mixture was stirred for an additional $5 \mathrm{~min}$, and then the precipitate was allowed to settle and the solution was decanted. The solid was washed with additional $\mathrm{Et}_{2} \mathrm{O}(2 \mathrm{~mL})$ and then dried in vacuo to give analytically pure product as a white microcrystalline solid. Yield: $80 \mathrm{mg}(0.19 \mathrm{mmol}, 80 \%)$.

Anal. calcd for $\mathrm{C}_{14} \mathrm{H}_{15} \mathrm{PIBF}_{4}$ : C, 39.29; H, 3.53. Found: C, 39.50; H, 3.59. HRMS calcd for $\mathrm{C}_{14} \mathrm{H}_{15} \mathrm{PI}: \mathrm{m} / \mathrm{z}$ 340.9956. Found: $\mathrm{m} / \mathrm{z} 340.9961 .{ }^{31} \mathrm{P}\left\{{ }^{1} \mathrm{H}\right\}$ NMR $\left(\mathrm{CD}_{3} \mathrm{CN}\right): \delta-18.9$ (broad). ${ }^{31} \mathrm{P}$ $\operatorname{NMR}\left(\mathrm{CD}_{3} \mathrm{CN}\right): \delta-18.9$ (br t, $\left.{ }^{1} \mathrm{~J}_{\mathrm{PH}}=517\right) .{ }^{1} \mathrm{H}$ NMR $\left(\mathrm{CD}_{3} \mathrm{CN}\right): \delta 7.92-7.79(\mathrm{~m}, 4 \mathrm{H}, \mathrm{Ar}), 7.70-$ $7.64(\mathrm{~m}, 2 \mathrm{H}, \mathrm{Ar}), 7.40-7.30$ (m, 2H, Ar), 7.03-6.97 (m, 1H, Ar), 7.01 (broad d of m, ${ }^{1} \mathrm{~J}_{\mathrm{PH}}=517,2 \mathrm{H}$, $\left.\mathrm{PH}_{2}\right), 3.14-3.05(\mathrm{~m}, 2 \mathrm{H}), 2.92-2.80$ (br m, 2H). ${ }^{13} \mathrm{C}\left\{{ }^{1} \mathrm{H}\right\}$ NMR $\left(\mathrm{CD}_{3} \mathrm{CN}\right): \delta 142.4(\mathrm{~d}, \mathrm{~J}=16, \mathrm{Ar})$, 141.2 (Ar), 136.2 (br, Ar), 135.5 (d, J = 11, Ar), 131.3 (Ar), 131.2 (Ar), 131.1 (Ar), 130.6 (Ar), 130.4 (Ar), 100.7 (C-I), $35.1\left(\mathrm{CH}_{2}\right), 18.7\left(\mathrm{~d}, \mathrm{~J}=45, \mathrm{CH}_{2}\right)$.

\section{$o-\mathrm{IC}_{6} \mathrm{H}_{4} \mathrm{CH}_{2} \mathrm{CH}_{2} \mathrm{PH}(\mathrm{Cy})(9 \mathrm{~b})$}

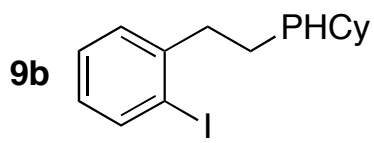

(2-(2'-iodophenyl)ethyl)cyclohexylphosphine-borane $(\mathbf{8 b}, 320 \mathrm{mg}, 0.89 \mathrm{mmol})$ and diethylamine $(0.92 \mathrm{~mL}, 8.89 \mathrm{mmol})$ were placed in an ampule under $\mathrm{N}_{2}$ and heated to $50{ }^{\circ} \mathrm{C}$ for $4 \mathrm{~h}$. The reaction mixture was then cooled to room temperature and excess diethylamine was removed in vacuo. The residue was dissolved in petroleum ether and filtered through a thick plug of silica in a glovebox. 
The silica was washed with ca. $30 \mathrm{~mL}$ of petroleum ether and the filtrate was then pumped to dryness in vacuo to give $200 \mathrm{mg}(0.58 \mathrm{mmol}, 65 \%$ yield $)$ of the product as a colorless mobile oil shown to be pure by NMR spectroscopy. For elemental analysis, the air-sensitive oil was converted to its white crystalline $\mathrm{HBF}_{4}$ salt $\mathbf{9 b} \cdot \mathbf{H B F}_{4}$ (see below).

${ }^{31} \mathrm{P}\left\{{ }^{1} \mathrm{H}\right\}$ NMR $\left(\mathrm{C}_{6} \mathrm{D}_{6}\right): \delta-48.4 .{ }^{1} \mathrm{H}$ NMR $\left(\mathrm{C}_{6} \mathrm{D}_{6}\right): \delta 7.65(\mathrm{dd}, \mathrm{J}=7,1,1 \mathrm{H}, \mathrm{Ar}), 6.93-6.87$ (m, 2H, Ar), 6.50-6.47 (m, 1H, Ar), 3.07 (d of m, $\left.{ }^{1} \mathrm{~J}_{\mathrm{PH}}=194, \mathrm{PH}\right), 2.83-2.76(\mathrm{~m}, 2 \mathrm{H}), 1.87-1.79(\mathrm{~m}$, $2 \mathrm{H}), 1.77-1.73(\mathrm{~m}, 2 \mathrm{H}), 1.64-1.54(\mathrm{~m}, 4 \mathrm{H}), 1.20-1.08(\mathrm{~m}, 5 \mathrm{H}) .{ }^{13} \mathrm{C}\left\{{ }^{1} \mathrm{H}\right\} \mathrm{NMR}\left(\mathrm{C}_{6} \mathrm{D}_{6}\right): \delta 145.6(\mathrm{~d}$, $\mathrm{J}=9, \operatorname{Ar} \mathrm{q}), 139.8($ Ar), $129.5($ Ar), $128.5($ Ar), 128.0 (Ar, obscured by solvent), 100.5 (Ar q), 40.3 $\left(\mathrm{d}, \mathrm{J}=12, \mathrm{CH}_{2}\right), 32.8\left(\mathrm{~d}, \mathrm{~J}=7, \mathrm{CH}_{2}\right), 32.1\left(\mathrm{~d}, \mathrm{~J}=17, \mathrm{CH}_{2}\right), 31.4(\mathrm{~d}, \mathrm{~J}=8, \mathrm{CH}), 27.3(\mathrm{~d}, \mathrm{~J}=4$, $\left.\mathrm{CH}_{2}\right), 27.2\left(\mathrm{~d}, \mathrm{~J}=9, \mathrm{CH}_{2}\right), 26.5\left(\mathrm{~d}, \mathrm{~J}=1, \mathrm{CH}_{2}\right), 19.7\left(\mathrm{~d}, \mathrm{~J}=15, \mathrm{CH}_{2}\right)$.

\section{(2-(2'-iodophenyl)ethyl)cyclohexylphosphonium tetrafluoroborate $\left(9 \mathrm{~b} \cdot \mathbf{H B F}{ }_{4}\right)$}

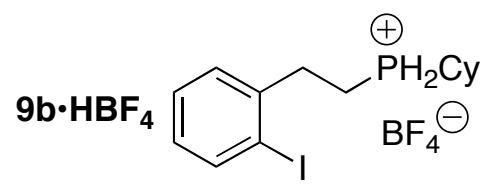

(2-(2'-iodophenyl)ethyl)cyclohexylphosphine (9b, $80 \mathrm{mg}, 0.23 \mathrm{mmol})$ was dissolved in $\mathrm{Et}_{2} \mathrm{O}$ (1 $\mathrm{mL})$ and added dropwise to a solution of $\mathrm{HBF}_{4} \bullet \mathrm{OMe}_{2}(35 \mathrm{mg}, 0.26 \mathrm{mmol})$ in $\mathrm{Et}_{2} \mathrm{O}(1 \mathrm{~mL})$. A white fluffy precipitate immediately formed. The mixture was stirred for $30 \mathrm{~min}$, and then the solvent was removed in vacuo. The white residue was washed with $\mathrm{Et}_{2} \mathrm{O}(2 \times 2 \mathrm{~mL})$, dried in vacuo and recrystallized by layering a solution in $\mathrm{MeCN}(2 \mathrm{~mL})$ with $\mathrm{Et}_{2} \mathrm{O}(10 \mathrm{~mL})$ and storing at $-30{ }^{\circ} \mathrm{C}$ for one day. The product was isolated as colorless needles and dried. Yield: $77 \mathrm{mg}$ (0.19 mmol, 77\%).

Anal. calcd for $\mathrm{C}_{14} \mathrm{H}_{21} \mathrm{PIBF}_{4}$ : C, 38.75; H, 4.88. Found: C, 38.67; H, 4.94. ${ }^{31} \mathrm{P}\left\{{ }^{1} \mathrm{H}\right\}$ NMR $\left(\mathrm{CD}_{3} \mathrm{CN}\right): \delta-11.3$ (broad). ${ }^{1} \mathrm{H}$ NMR $\left(\mathrm{CD}_{3} \mathrm{CN}\right): \delta 7.91$ (dd, $\left.\mathrm{J}=8,1,1 \mathrm{H}, \mathrm{Ar}\right), 7.43-7.37$ (m, 2H, Ar), 7.06-7.03 (m, 1H, Ar), 5.94 (broad d, J = 454, 2H, PH), 3.16-3.11 (m, 2H), 2.61-2.55 (m, 2H), 2.55-2.48 (m, 1H), 2.03-1.96 (m, 2H), 1.87-1.80 (m, 2H), 1.74-1.69 (m, 1H), 1.54-1.45 (m, 2H), 1.42-1.33 (m, 2H), 1.32-1.25 (m, 1H). ${ }^{13} \mathrm{C}\left\{{ }^{1} \mathrm{H}\right\}$ NMR $\left(\mathrm{CD}_{3} \mathrm{CN}\right): \delta 142.4(\mathrm{~d}, \mathrm{~J}=14, \mathrm{Ar} \mathrm{q}), 141.0$ (Ar), 130.8 (Ar), 130.4 (Ar), 130.3 (Ar), 100.4 (Ar-I), 35.3 (d, J = 4), 28.2 (d, J = 3), 27.4 (d, J = 44), $26.5(\mathrm{~d}, \mathrm{~J}=15), 25.5(\mathrm{~d}, \mathrm{~J}=2), 14.3(\mathrm{~d}, \mathrm{~J}=44)$. 
$o-\mathrm{IC}_{6} \mathrm{H}_{4} \mathrm{CH}_{2} \mathrm{CH}_{2} \mathrm{PH}(\mathrm{Men})(9 \mathrm{c})$

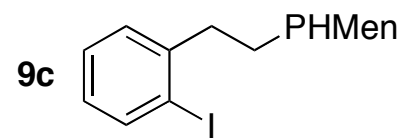

A degassed solution of $o-\mathrm{IC}_{6} \mathrm{H}_{4} \mathrm{CH}_{2} \mathrm{CH}_{2} \mathrm{PH}(\mathrm{Men})\left(\mathrm{BH}_{3}\right)(\mathbf{8 c}, 438.1 \mathrm{mg}, 1.05 \mathrm{mmol})$ in toluene $(10 \mathrm{~mL})$ was heated to $60{ }^{\circ} \mathrm{C}$, at which temperature a solution of DABCO (130 mg, $1.5 \mathrm{mmol}, 1.1$ equiv) in THF ( $5 \mathrm{~mL})$ was added via syringe. The reaction mixture was stirred overnight at $60{ }^{\circ} \mathrm{C}$. The solvent was removed in vacuo and the reaction flask was brought into the glove box. The product was purified by passing it through a short pad of silica (in a pipette, $5 \mathrm{~mm}$ x $30 \mathrm{~mm}$ ) and washing the pad further with $40 \mathrm{~mL}$ of hexanes. Drying in vacuo resulted in $348 \mathrm{mg}(82 \%)$ of the desired product, isolated as a colorless oil. The diastereomeric ratio of the product was 1.2:1. Spectra are reported for the mixture of diastereomers.

Anal. Calcd for $\mathrm{C}_{18} \mathrm{H}_{28}$ IP: C, 53.74; H, 7.02. Found: C, 52.48; H, 6.59. HRMS calcd for $\mathrm{C}_{18} \mathrm{H}_{29} \mathrm{IP}(\mathrm{M}+\mathrm{H})^{+}: \mathrm{m} / \mathrm{z}$ 403.1052. Found: $\mathrm{m} / \mathrm{z} 403.1039 .{ }^{31} \mathrm{P}\left\{{ }^{1} \mathrm{H}\right\}$ NMR (THF): $\delta-73.6$ (minor), -80.2 (major). ${ }^{1} \mathrm{H}$ NMR $\left(\mathrm{C}_{6} \mathrm{D}_{6}\right): \delta 7.63(\mathrm{~d}, \mathrm{~J}=8,2 \mathrm{H}, \mathrm{Ar}), 6.94-6.86(\mathrm{~m}, 4 \mathrm{H}, \mathrm{Ar}), 6.51-6.45$ (m, 2H, Ar), 3.31 (dm, J = 198, 1H, P-H), 3.04 (dm, J = 160, 1H, P-H), 2.88-2.73 (m, 5H, overlapped with previous signal), 2.42-2.32 (m, 1H, CH), 2.14-2.04 (m, 1H, CH), 1.99-1.68 (m, 6H), 1.68-1.52 (m, 7H), 1.49-1.39 (m, 1H, CH), 1.30-1.13 (m, 4H), 1.13-1.02 (m, 2H), 1.02-0.94 (m, 1H), $0.90(\mathrm{~d}, \mathrm{~J}=$ 7, 3H, Me), 0.88 (d, J = 7, 3H, Me), $0.84(\mathrm{~d}, \mathrm{~J}=6.5,3 \mathrm{H}, \mathrm{Me}), 0.83$ (d, J = 6.5, 3H, Me, overlapping with previous signal), $0.78(\mathrm{~d}, \mathrm{~J}=7,3 \mathrm{H}, \mathrm{Me}), 0.74(\mathrm{~d}, \mathrm{~J}=7,3 \mathrm{H}, \mathrm{Me}) .{ }^{13} \mathrm{C}\left\{{ }^{1} \mathrm{H}\right\} \mathrm{NMR}\left(\mathrm{C}_{6} \mathrm{D}_{6}\right): \delta$ 145.5 (d, J = 8, quat, Ar), 145.4 (d, J = 10, quat, Ar), 139.7 (Ar), 129.5 (Ar), 129.4 (Ar), 128.5 (Ar), 128.4 (Ar), 128.2 (Ar), 128.0 (Ar), 127.9 (Ar), 100.5 (quat, Ar), 100.4 (quat, Ar), 47.3 (d, J = 12, $\mathrm{CH}), 46.3(\mathrm{~d}, \mathrm{~J}=10, \mathrm{CH}), 43.4\left(\mathrm{~d}, \mathrm{~J}=1, \mathrm{CH}_{2}\right), 40.9\left(\mathrm{~d}, \mathrm{~J}=8, \mathrm{CH}_{2}\right), 40.6\left(\mathrm{~d}, \mathrm{~J}=9, \mathrm{CH}_{2}\right), 40.3(\mathrm{~d}, \mathrm{~J}$ $\left.=14, \mathrm{CH}_{2}\right), 35.3\left(\mathrm{CH}_{2}\right), 35.2\left(\mathrm{CH}_{2}\right), 35.3(\mathrm{~d}, \mathrm{~J}=12, \mathrm{CH}$, overlapped with previous signal), $34.1(\mathrm{~d}$, $\mathrm{J}=5, \mathrm{CH}), 33.8(\mathrm{~d}, \mathrm{~J}=11, \mathrm{CH}), 33.6(\mathrm{~d}, \mathrm{~J}=$ 7, CH), $28.8(\mathrm{~d}, \mathrm{~J}=14, \mathrm{CH}), 28.7(\mathrm{~d}, \mathrm{~J}=11, \mathrm{CH})$, $25.3\left(\mathrm{~d}, \mathrm{~J}=8, \mathrm{CH}_{2}\right), 25.0\left(\mathrm{~d}, \mathrm{~J}=8, \mathrm{CH}_{2}\right), 22.8(\mathrm{Me}), 22.7(\mathrm{Me}), 21.9(\mathrm{Me}), 21.6(\mathrm{Me}), 20.3(\mathrm{~d}, \mathrm{~J}=$ 15, $\left.\mathrm{CH}_{2}\right), 18.9\left(\mathrm{~d}, \mathrm{~J}=15, \mathrm{CH}_{2}\right), 15.5(\mathrm{Me}), 15.3(\mathrm{Me})$. 


\section{Alternative Method for Phosphine-Borane Deprotection (Conversion of 8a-c into 9a-c)}

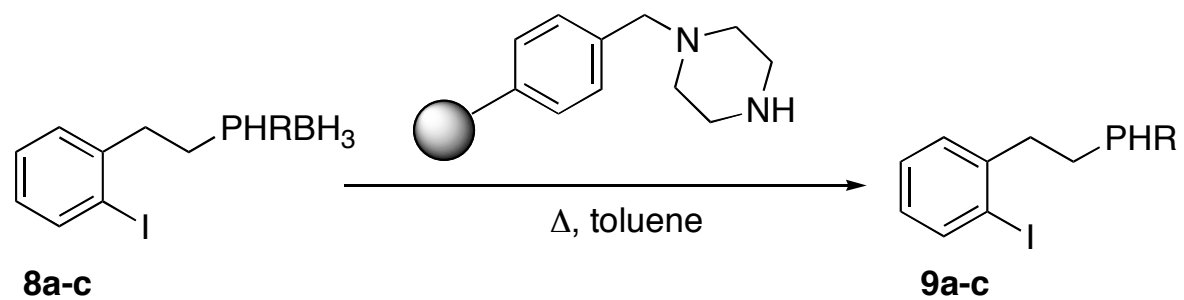

The general procedure is described for $\mathrm{R}=\mathrm{Ph}(\mathbf{8 a})$; the table also summarizes results for $\mathbf{8 b - c}{ }^{9}$ Under $\mathrm{N}_{2}$, piperazinomethyl polystyrene (Matrix Innovation (www.matrix-innovation.com) catalog number 3-221-1330, 1\% DVB, 100-200 mesh, $2.7 \mathrm{mmol} / \mathrm{g}$ loading, $1.0 \mathrm{~g}, 2.7 \mathrm{mmol}$ ) was suspended in $15 \mathrm{~mL}$ of dry toluene. A solution of $\mathbf{8 a}(0.48 \mathrm{~g}, 1.4 \mathrm{mmol})$ in $10 \mathrm{~mL}$ of dry toluene was added via cannula. The mixture was stirred at $50{ }^{\circ} \mathrm{C}$ for $12 \mathrm{~h}$; the resin particles swelled. After the borane was removed, as monitored by ${ }^{31} \mathrm{P}$ NMR spectroscopy, the suspension was filtered via cannula and the toluene was removed in vacuo to give the desired phosphine as a colorless oil (390 $\mathrm{mg}, 84 \%)$.

\begin{tabular}{|l|l|l|l|l|l|l|}
\hline $\mathrm{R}$ & $\mathrm{mmol} \mathbf{8}$ & mmol resin & $\mathrm{T}\left({ }^{\circ} \mathrm{C}\right)$ & Solvent & Time (h) & Yield (\%) \\
\hline Ph (8a) & 1.4 & 2.7 & 50 & toluene & 12 & 84 \\
\hline Cy (8b) & 0.53 & 1.1 & 60 & toluene & 48 & 80 \\
\hline Men (8c) & 0.84 & 1.7 & 60 & toluene & 48 & 80 \\
\hline
\end{tabular}




\section{Additional Information for Scheme 2: Pd-Catalyzed Intramolecular Phosphination}

Figure S1. Structures of the diphosphine ligands in the catalyst precursors Pd(diphos*)(transstilbene). ${ }^{10}$

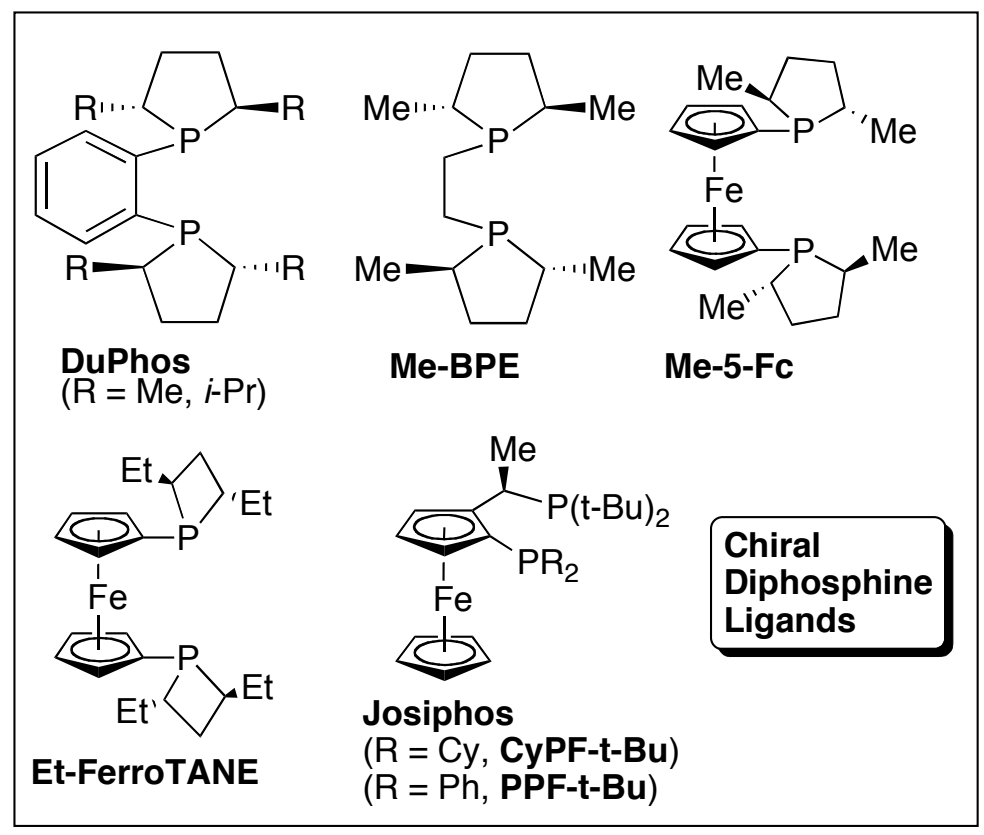

Catalyst Screening in Cyclization of 9a (General Method for 9a-c) A solution of 9a (40 $\mathrm{mg}, 0.12 \mathrm{mmol})$ in toluene $(0.5 \mathrm{~mL})$ was added to a solution of the catalyst precursor $\left(\operatorname{Pd}\left(\right.\right.$ diphos* $\left.^{*}\right)($ trans-stilbene), $5 \mathrm{~mol} \%)$ in a few drops of toluene. Typically on addition of the phosphine the solution darkened somewhat initially to orange and then the color faded back to yellow after a few seconds. $\mathrm{NaOSiMe}_{3}\left(118 \mu \mathrm{L}, 1.0 \mathrm{M}\right.$ solution in THF, $\left.1.18 \times 10^{-4} \mathrm{~mol}\right)$ was then added causing the solution to darken somewhat, and the mixture was transferred to an NMR tube. The reaction mixture was then monitored periodically by ${ }^{31} \mathrm{P}\left\{{ }^{1} \mathrm{H}\right\}$ NMR spectroscopy. A white precipitate $(\mathrm{NaI})$ formed during the course of catalysis. When the reaction was complete, the mixture was pumped to dryness in vacuo. The residue was then slurried in petroleum ether $(1 \mathrm{~mL})$ and the catalyst byproduct removed by chromatography on a small silica column eluting with petroleum ether (15-20 mL). The clear solution was then pumped to dryness in a tared vial, to calculate the yield, to give a colorless oily product, which generally solidified on standing. The 
product was confirmed to be benzophospholane 10a by comparison of NMR spectroscopic data to the literature data (see below). Note: the reactions in Table 1 have not been optimized, so the reported times do not necessarily correspond to relative rates. Unlike the screening reactions, done in NMR tubes as described above, larger-scale reactions, such as entry 2, were carried out in flasks with stirring, which may affect the reaction rate.

ee determination for 10a and 10b: The general method is described for 10a. Phosphine 10a (typically $20 \mathrm{mg}$ ) as a solution in $\mathrm{C}_{6} \mathrm{D}_{6}(0.5 \mathrm{~mL})$ was added to $\left.\mathrm{Pd}\left((\mathrm{S})-\mathrm{Me}_{2} \mathrm{NCH}(\mathrm{Me}) \mathrm{C}_{6} \mathrm{H}_{4}\right)(\mu-\mathrm{Cl})\right)_{2}$ (0.6 equiv), and the mixture was shaken until all the Pd complex dissolved. This solution displayed well-resolved resonances at $\delta 45.4$ (a) and $45.3(\mathbf{b})$ in the ${ }^{31} \mathrm{P}\left\{{ }^{1} \mathrm{H}\right\} \mathrm{NMR}$ spectrum and at $\delta 8.30$ (t, $\mathrm{J}=8, \mathbf{b})$ and $7.95(\mathrm{t}, \mathrm{J}=8, \mathbf{a})$ in the ${ }^{1} \mathrm{H}$ NMR spectrum (where (a) and (b) represent the resonances belonging to each diastereomer) from which the ee was determined. The ee values in Table 1 in the text are those obtained from analysis of the ${ }^{1} \mathrm{H}$ NMR spectra, in which the signals were better baseline resolved; the ${ }^{31} \mathrm{P}$ NMR spectra gave consistent results.

Note: catalysts with $(R, R)-\mathrm{Me}-\mathrm{DuPhos}$ and $(R, R)$-Me-BPE ligands gave preferentially 10a which yielded diastereomer $\mathbf{b}$ of the $\operatorname{Pd}(\mathbf{1 0 a})\left({ }^{*} \mathrm{C} \sim \mathrm{N}\right)(\mathrm{Cl})$ complex, while catalysts with $(R, R)-i-\operatorname{Pr}-$ DuPhos and (S,S)-Me-5-Fc favored the other enantiomer of 10a, which gave diastereomer a of the Pd complex.

Table S2. Selected NMR Data $\left(\mathrm{C}_{6} \mathrm{D}_{6}\right)$ Used to Determine the ee of Phosphines 10a and 11a

\begin{tabular}{|c|c|c|}
\hline Phosphine & ${ }^{3} \mathbf{P}$ NMR & ${ }^{\mathrm{T}} \mathrm{H}$ NMR \\
\hline $\mathbf{1 0 a}$ & $\begin{array}{l}45.4(\mathbf{a}) \\
45.3(\mathbf{b})\end{array}$ & $\begin{array}{l}7.95(\mathrm{t}, \mathrm{J}=8, \mathbf{a}) \\
8.30(\mathrm{t}, \mathrm{J}=8, \mathbf{b})\end{array}$ \\
\hline $\mathbf{1 0 b}$ & $\begin{array}{l}55.5(\mathbf{a}) \\
54.8(\mathbf{b})\end{array}$ & $\begin{array}{l}8.46(\mathrm{t}, \mathrm{J}=7, \mathbf{a}) \\
8.58(\mathrm{t}, \mathrm{J}=7, \mathbf{b})\end{array}$ \\
\hline
\end{tabular}

Catalyst Screening in Cyclization of 9b. The general procedure described above for 9a was followed. No color change from pale yellow was observed on addition of the phosphine. For all 
catalysts tested, a white precipitate of $\mathrm{NaI}$ was immediately observed on addition of base and the reaction was shown to be complete by ${ }^{31} \mathrm{P}\left\{{ }^{1} \mathrm{H}\right\}$ NMR after $20 \mathrm{~min}$; workup gave 10b as a colorless oil. Its ee was determined as described above by analysis of ${ }^{1} \mathrm{H}$ and ${ }^{31} \mathrm{P}$ NMR spectra after complexation to a chiral Pd fragment (Table S2); in all cases racemic (within experimental error) phosphine 10b was formed.

\section{Characterization Data for the Benzophospholanes}

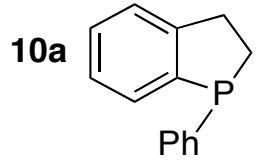

Phosphine 10a is a known compound (Quin, L. D.; Rao, N. S. J. Org. Chem. 1983, 48, 37543759), which was isolated as a colorless oily solid. ${ }^{31} \mathrm{P}\left\{{ }^{1} \mathrm{H}\right\} \operatorname{NMR}\left(\mathrm{C}_{6} \mathrm{D}_{6}\right): \delta-3.0$ (lit. $\left.\delta-3.9\right)$. The ${ }^{1} \mathrm{H}$ NMR spectrum was not reported by Quin and Rao. ${ }^{1} \mathrm{H}$ NMR $\left(\mathrm{C}_{6} \mathrm{D}_{6}\right): \delta 7.53(\mathrm{~m}, 1 \mathrm{H}, \mathrm{Ar})$, 7.22-6.94 (overlapping m, 8H, Ar), 2.97-2.85 (m, 1H), 2.74-2.62 (m, 1H), 2.09-1.92 (m, 1H), 1.84$1.76(\mathrm{~m}, 1 \mathrm{H})$. Our ${ }^{13} \mathrm{C}$ NMR data is consistent with that of Quin and Rao, although they reported only 6 of the expected 10 Ar peaks. ${ }^{13} \mathrm{C}\left\{{ }^{1} \mathrm{H}\right\} \operatorname{NMR}\left(\mathrm{C}_{6} \mathrm{D}_{6}\right): \delta 150.1(\mathrm{~d}, \mathrm{~J}=2, \mathrm{Ar}), 141.2(\mathrm{~d}, \mathrm{~J}=8$, Ar), 140.8 (d, J = 24, Ar), 132.2 (Ar), 132.1 (Ar), 132.0 (Ar), 129.6 (Ar), 128.9 (d, J = 6, Ar), 127.4 $(\mathrm{d}, \mathrm{J}=8, \mathrm{Ar}), 125.5(\mathrm{~d}, \mathrm{~J}=2, \mathrm{Ar}), 34.9\left(\mathrm{~d}, \mathrm{~J}=6, \mathrm{CH}_{2}\right), 28.3\left(\mathrm{~d}, \mathrm{~J}=10, \mathrm{CH}_{2}\right)$.

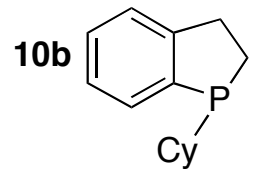

Colorless oil, ${ }^{31} \mathrm{P}\left\{{ }^{1} \mathrm{H}\right\}$ NMR $\left(\mathrm{C}_{6} \mathrm{D}_{6}\right): \delta 4.3 .{ }^{1} \mathrm{H}$ NMR $\left(\mathrm{C}_{6} \mathrm{D}_{6}\right): \delta 7.56-7.54(\mathrm{~m}, 1 \mathrm{H}, \mathrm{Ar}), 7.12-$ $7.03(\mathrm{~m}, 3 \mathrm{H}, \mathrm{Ar}), 3.12-3.05(\mathrm{~m}, 1 \mathrm{H}), 2.86-2.78(\mathrm{~m}, 1 \mathrm{H}), 1.90-1.80(\mathrm{~m}, 1 \mathrm{H}), 1.75-1.57(\mathrm{~m}, 5 \mathrm{H})$, 1.53-1.51 (m, 1H), 1.41-1.34 (m, 1H), 1.25-1.12 (m, 2H), 1.11-1.03 (m, 2H), 0.99-0.94 (m, 1H). ${ }^{13} \mathrm{C}\left\{{ }^{1} \mathrm{H}\right\} \operatorname{NMR}\left(\mathrm{C}_{6} \mathrm{D}_{6}\right): \delta 148.9(\mathrm{Ar} q), 142.1(\mathrm{~d}, \mathrm{~J}=13, \mathrm{Ar} q), 131.3(\mathrm{~d}, \mathrm{~J}=24, \operatorname{Ar}), 128.6$ (Ar), $126.4(\mathrm{~d}, \mathrm{~J}=7, \operatorname{Ar}), 124.8(\mathrm{~d}, \mathrm{~J}=2$, Ar), $36.4(\mathrm{~d}, \mathrm{~J}=16), 35.0(\mathrm{~d}, \mathrm{~J}=6), 30.3$ (d, J = 15), 29.6 (d, J $=13), 27.1(\mathrm{~d}, \mathrm{~J}=11), 26.9(\mathrm{~d}, \mathrm{~J}=10), 26.6(\mathrm{~d}, \mathrm{~J}=1), 21.7(\mathrm{~d}, \mathrm{~J}=11)$.

\section{1-menthylbenzophospholane (10c)}




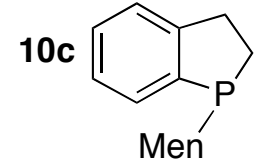

Method I (Pd((R,R)-Me-DuPhos)(trans-stilbene) as a catalyst precursor):To a stirring slurry of $\operatorname{Pd}((R, R)-M e-D u P h o s)($ trans-stilbene $)(7 \mathrm{mg}, 0.01 \mathrm{mmol}, 5 \mathrm{~mol} \%)$ in toluene $(0.5 \mathrm{~mL})$ was added $o$ - $\mathrm{IC}_{6} \mathrm{H}_{4} \mathrm{CH}_{2} \mathrm{CH}_{2} \mathrm{PH}(\mathrm{Men})(9 \mathrm{c}, 92.4 \mathrm{mg}, 0.23 \mathrm{mmol})$ as a solution in toluene $(1 \mathrm{~mL})$ followed by $\mathrm{NaOSiMe}_{3}(230 \mu \mathrm{L}, 0.23 \mathrm{mmol}, 1 \mathrm{M}$ solution in THF). The reaction mixture changed color from slightly yellow to dark-orange and precipitate was observed after $15 \mathrm{~min}$. The reaction was monitored by ${ }^{31} \mathrm{P}$ NMR spectroscopy. After the reaction was done (ca. $1 \mathrm{~h}$ ) the product phosphine was isolated by column chromatography on a pipette-size column (silica, petroleum ether as an eluent) as a colorless oil (30 $\mathrm{mg}, 48 \%)$. The compound was formed as a 1:1 ratio of diastereomers. The spectra are reported for the mixture of diastereomers, unless otherwise stated.

Anal. Calcd. For $\mathrm{C}_{18} \mathrm{H}_{27}$ P: C, 78.79; H, 9.92. Found: C, 78.66; H, 10.45. HRMS (EI) calcd for $\mathrm{C}_{18} \mathrm{H}_{27} \mathrm{P}: \mathrm{m} / \mathrm{z}$ 274.1850. Found: $\mathrm{m} / \mathrm{z} 274.1851 .{ }^{31} \mathrm{P}\left\{{ }^{1} \mathrm{H}\right\} \mathrm{NMR}$ (toluene-d $\mathrm{d}_{8}$ ): $\delta$ 1.9, 0.6. ${ }^{1} \mathrm{H}$ NMR $\left(\mathrm{C}_{6} \mathrm{D}_{6}\right): \delta 7.58-7.53(\mathrm{~m}, 1 \mathrm{H}), 7.45-7.40(\mathrm{~m}, 1 \mathrm{H}), 7.12-7.03(\mathrm{~m}, 6 \mathrm{H}), 3.22-3.13(\mathrm{~m}, 1 \mathrm{H}), 3.13-3.03$ (m, 1H), 2.93-2.79 (m, 3H), 2.79-2.69 (m, 1H), 2.06-1.94 (m, 1H), 1.90-1.73 (m, 3H), 1.71-1.42 $(\mathrm{m}, 7 \mathrm{H}), 1.42-1.26(\mathrm{~m}, 2 \mathrm{H}), 1.21-1.09(\mathrm{~m}, 1 \mathrm{H}), 1.09-1.00(\mathrm{~m}, 2 \mathrm{H}), 1.00(\mathrm{~d}, \mathrm{~J}=6.5,3 \mathrm{H}, \mathrm{Me}$, overlapped with previous signal), $0.97(\mathrm{~d}, \mathrm{~J}=7.5,3 \mathrm{H}, \mathrm{Me}), 0.94(\mathrm{~d}, \mathrm{~J}=6.5,3 \mathrm{H}, \mathrm{Me}), 0.94-0.88$ (m, $2 \mathrm{H}$, overlapped with the previous signal), $0.86(\mathrm{~d}, \mathrm{~J}=7,3 \mathrm{H}, \mathrm{Me}), 0.80-0.69(\mathrm{~m}, 4 \mathrm{H}), 0.69(\mathrm{~d}, \mathrm{~J}=$ 6.5, 3H, Me, overlapped with previous signal), $0.66(\mathrm{~d}, \mathrm{~J}=7,3 \mathrm{H}, \mathrm{Me}) .{ }^{13} \mathrm{C}\left\{{ }^{1} \mathrm{H}\right\} \mathrm{NMR}\left(\mathrm{C}_{6} \mathrm{D}_{6}\right): \delta$ 149.6 (quat, $\operatorname{Ar}$ ), 148.7 (d, $\mathrm{J}=4$, quat, $\operatorname{Ar}$ ), 142.3 (d, $\mathrm{J}=12$, quat, $\operatorname{Ar}$ ), 140.8 (d, $\mathrm{J}=15$, quat, $\operatorname{Ar}$ ), $132.0(\mathrm{~d}, \mathrm{~J}=23, \operatorname{Ar}), 130.1$ (d, J = 23, Ar), 128.3 (Ar), 127.9 (Ar), 126.7 (d, J = 7, Ar), 126.2 (d, J = 7, Ar), 124.7 (d, J = 2, Ar), 124.6 (d, J = 2, Ar), 47.0 (d, J = 15, CH), 46.1 (d, J = 10, CH), 40.5 (d, J $=24, \mathrm{CH}), 38.3(\mathrm{~d}, \mathrm{~J}=22, \mathrm{CH}), 37.8\left(\mathrm{CH}_{2}\right), 36.7\left(\mathrm{~d}, \mathrm{~J}=4, \mathrm{CH}_{2}\right), 35.4\left(\mathrm{~d}, \mathrm{~J}=5, \mathrm{CH}_{2}\right), 35.3(\mathrm{~d}, \mathrm{~J}=$ 5, $\left.\mathrm{CH}_{2}\right), 35.3\left(\mathrm{CH}_{2}\right.$, overlapped with previous signal), $35.0\left(\mathrm{CH}_{2}\right), 33.7(\mathrm{~d}, \mathrm{~J}=2, \mathrm{CH}), 33.6(\mathrm{~d}, \mathrm{~J}=$ 4, CH), $28.7(\mathrm{~d}, \mathrm{~J}=17, \mathrm{CH}), 28.3(\mathrm{~d}, \mathrm{~J}=20, \mathrm{CH}), 25.7\left(\mathrm{~d}, \mathrm{~J}=\right.$ 7, $\left.\mathrm{CH}_{2}\right), 25.4\left(\mathrm{~d}, \mathrm{~J}=8, \mathrm{CH}_{2}\right), 23.2$ 
(d, J = 10, $\mathrm{CH}_{2}$ ), $22.7(\mathrm{Me}), 22.6(\mathrm{Me}), 21.8(\mathrm{Me}), 21.7(\mathrm{Me}), 18.4\left(\mathrm{~d}, \mathrm{~J}=13, \mathrm{CH}_{2}\right), 15.6(\mathrm{Me})$, $15.5(\mathrm{~d}, \mathrm{~J}=2, \mathrm{Me})$.

Method II (Pd(OAc) $)_{2}$ as a catalyst precursor, larger scale $)$ : To a stirring slurry of $\mathrm{Pd}(\mathrm{OAc})_{2}$ (6 mg, $0.03 \mathrm{mmol}, 9 \mathrm{~mol} \%)$ in toluene $(0.5 \mathrm{~mL})$ was added $o-\mathrm{IC}_{6} \mathrm{H}_{4} \mathrm{CH}_{2} \mathrm{CH}_{2} \mathrm{PH}(\mathrm{Men})(132 \mathrm{mg}$, $0.329 \mathrm{mmol})$ as a solution in toluene $(1 \mathrm{~mL})$ followed by $\mathrm{NaOSiMe}_{3}(330 \mu \mathrm{L}, 0.330 \mathrm{mmol}, 1 \mathrm{M}$ solution in THF). The reaction mixture changed color from slightly yellow to orange and precipitate was observed after $15 \mathrm{~min}$. The reaction was monitored by ${ }^{31} \mathrm{P}$ NMR spectroscopy. After the reaction was done (ca. $20 \mathrm{~h}$ ) the product phosphine was isolated by column chromatography on a 0.5 inch $x 4$ inch column (silica, petroleum ether as an eluent) as a colorless oil (44 mg, 49\%). The compound was formed as a 1.2:1 ratio of diastereomers.

\section{1-phenylbenzophospholane-borane (11a)}

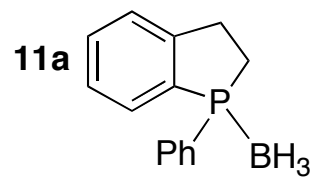

Phosphine-borane 11a was prepared either by treatment of $\mathbf{1 0 a}$ with $\mathrm{BH}_{3}\left(\mathrm{SMe}_{2}\right)$, as described in detail below for $\mathbf{1 1 b}$, or by direct cyclization of $\mathbf{8 a}$ (see below).

Anal calc for $\mathrm{C}_{14} \mathrm{H}_{16} \mathrm{BP}: \mathrm{C}, 74.38 ; \mathrm{H}, 7.13$. Found: $\mathrm{C}, 73.95 ; \mathrm{H}, 7.05$. HRMS m/z calcd. for $\mathrm{C}_{14} \mathrm{H}_{15} \mathrm{BP}(\mathrm{M}-\mathrm{H})^{+}: \mathrm{m} / \mathrm{z}$ 225.1004. Found: $\mathrm{m} / \mathrm{z} 225.1025 .{ }^{31} \mathrm{P}\left\{{ }^{1} \mathrm{H}\right\} \mathrm{NMR}\left(\mathrm{CDCl}_{3}\right): \delta 38.0$ (br m). ${ }^{1} \mathrm{H}$ NMR $\left(\mathrm{CDCl}_{3}\right): \delta 7.63$ (br t, J = 8, 1H, Ar), 7.57-7.47 (m, 4H, Ar), 7.45-7.35 (m, 4H, Ar), 3.40$3.32(\mathrm{~m}, 2 \mathrm{H}), 2.56-2.33(\mathrm{~m}, 2 \mathrm{H}), 1.62-0.60$ (br q, 3H, BH 3$).{ }^{13} \mathrm{C}\left\{{ }^{1} \mathrm{H}\right\}$ NMR $\left(\mathrm{CDCl}_{3}\right): \delta 148.7(\mathrm{~d}, \mathrm{~J}$ $=15, \operatorname{Ar} q), 131.9(\mathrm{~d}, \mathrm{~J}=8, \operatorname{Ar}), 131.9(\mathrm{~d}, \mathrm{~J}=2, \operatorname{Ar}), 131.5(\mathrm{~d}, \mathrm{~J}=45, \operatorname{Ar} \mathrm{q}), 131.5(\mathrm{~d}, \mathrm{~J}=2, \operatorname{Ar})$, 131.1 (d, J = 7, Ar q), 130.5 (d, J = 13, Ar), 129.0 (d, J = 10, Ar), 128.2 (d, J = 9, Ar), 125.9 (d, J = 8, Ar), $31.9\left(\mathrm{~d}, \mathrm{~J}=4, \mathrm{CH}_{2}\right), 26.2\left(\mathrm{~d}, \mathrm{~J}=38, \mathrm{CH}_{2}\right)$.

\section{1-cyclohexylbenzophospholane-borane (11b)}

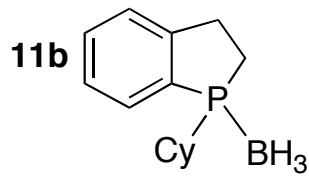


A solution of 1-cyclohexylbenzophospholane $\left(\mathbf{1 0 b}, 30 \mathrm{mg}, 1.37 \times 10^{-4} \mathrm{~mol}\right)$ in THF $(0.5 \mathrm{~mL})$ was placed in an NMR tube, which was sealed with a rubber septum. $0.5 \mathrm{~mL}$ of $\mathrm{BH}_{3}\left(\mathrm{SMe}_{2}\right)(1 \mathrm{x}$ $10^{-3} \mathrm{~mol}, 2.0 \mathrm{M}$ solution in THF) was then added by syringe and the reaction was observed to go to completion by NMR spectroscopy. The solution was then poured into $\mathrm{H}_{2} \mathrm{O}(10 \mathrm{~mL})$ cautiously and extracted with $\mathrm{Et}_{2} \mathrm{O}(3 \times 10 \mathrm{~mL})$. The combined $\mathrm{Et}_{2} \mathrm{O}$ extracts were dried over $\mathrm{MgSO}_{4}$, filtered and pumped to dryness in vacuo to yield $46 \mathrm{mg}$ of the crude product as a white sticky oil. The oil was dissolved in petroleum ether and passed through a silica plug column eluting with $20 \mathrm{~mL}$ of petroleum ether to remove impurities. The product was then removed from the silica by eluting with $\mathrm{CH}_{2} \mathrm{Cl}_{2}$ and the solution was dried in vacuo to yield $25 \mathrm{mg}$ (78\% yield) of a colorless oil.

Anal. Calcd for $\mathrm{C}_{14} \mathrm{H}_{22} \mathrm{BP}$ : C, 72.44; H, 9.55. Found: C, 72.08; H, 9.09. HRMS calcd for $\mathrm{C}_{14} \mathrm{H}_{22} \mathrm{BPNa}(\mathrm{M}+\mathrm{Na})^{+}: \mathrm{m} / \mathrm{z}$ 255.1450. Found: $\mathrm{m} / \mathrm{z} 255.1438$. ${ }^{31} \mathrm{P}\left\{{ }^{1} \mathrm{H}\right\} \mathrm{NMR}\left(\mathrm{CDCl}_{3}\right): \delta 46.2$ (br m). ${ }^{1} \mathrm{H} \mathrm{NMR}\left(\mathrm{CDCl}_{3}\right): \delta$ 7.62-7.59 (m, 1H, Ar), 7.45-7.42 (m, 1H, Ar), 7.36-7.32 (m, 2H, Ar), 3.34-3.22 (m, 2H), 2.32-2.26 (m, 1H), 2.22-2.14 (m, 1H), $1.87(\mathrm{~m}, 1 \mathrm{H}), 1.82-1.73$ (br m, 4H), 1.69 (br m, 1H), 1.37-1.28 (br m, 1H), 1.25-1.13 (m, 4H), 0.98-0.42 (br q, J = 93, 3H, BH $).{ }^{13} \mathrm{C}\left\{{ }^{1} \mathrm{H}\right\}$ $\operatorname{NMR}\left(\mathrm{CDCl}_{3}\right): \delta 148.3(\mathrm{~d}, \mathrm{~J}=13, \operatorname{Ar} \mathrm{q}), 131.4(\mathrm{~d}, \mathrm{~J}=2$, Ar), $130.9(\mathrm{~d}, \mathrm{~J}=54, \operatorname{Ar} \mathrm{q}), 130.6(\mathrm{~d}, \mathrm{~J}=$ 12, Ar), 127.5 (d, J = 9, Ar), 125.7 (d, J = 7, Ar), 35.4 (d, J = 29, CH), 32.4 (d, J = 4, $\mathrm{CH}_{2}$ ), 26.9 $\left(\mathrm{CH}_{2}\right), 26.63\left(\mathrm{~d}, \mathrm{~J}=21, \mathrm{CH}_{2}\right), 26.6\left(\mathrm{~d}, \mathrm{~J}=2, \mathrm{CH}_{2}\right), 26.5\left(\mathrm{~d}, \mathrm{~J}=1, \mathrm{CH}_{2}\right), 25.9\left(\mathrm{~d}, \mathrm{~J}=1, \mathrm{CH}_{2}\right), 20.3$ $\left(\mathrm{d}, \mathrm{J}=37, \mathrm{CH}_{2}\right)$.

\section{Phenylbenzophospholane sulfide (12)}

12

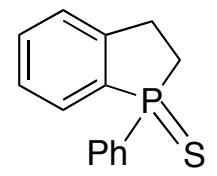

Phosphine-borane $11 \mathrm{a}(0.65 \mathrm{~g}, 2.9 \mathrm{mmol})$ was dissolved in diethyl ether $(5 \mathrm{~mL})$, diethylamine $(3$ $\mathrm{mL}, 29 \mathrm{mmol}$ ) was added, and the mixture was stirred overnight. ${ }^{31} \mathrm{P}$ NMR monitoring showed that deprotection was complete. Solid sulfur (140 mg, $4.35 \mathrm{mmol}$ ) was added to the phosphine solution, which turned darker orange, with some orange solid present. After stirring for $4 \mathrm{~h}$, the ${ }^{31} \mathrm{P} \mathrm{NMR}$ spectrum of the mixture showed that reaction was complete. The solvent was removed on a rotary 
evaporator. The residue was dissolved in $\mathrm{CH}_{2} \mathrm{Cl}_{2}$ and the solution was filtered through Celite, then concentrated under vacuum and treated with ether to precipitate insoluble impurities. The solution was decanted and the remaining solid was washed with ether. The combined solutions were concentrated under vacuum to give $670 \mathrm{mg}$ of crude product as an orange oil. Dry-column flash chromatography with $\mathrm{CH}_{2} \mathrm{Cl}_{2}$ gave $600 \mathrm{mg}$ of white solid (85\% yield).

This reaction was also successfully scaled up, with a simpler workup: 11a (3.1 g, $13.7 \mathrm{mmol})$ was dissolved in diethyl ether $(10 \mathrm{~mL})$, diethylamine $(14.2 \mathrm{~mL}, 137 \mathrm{mmol})$ was added, and the mixture was stirred for $5 \mathrm{~h}$. Sulfur $(673 \mathrm{mg}, 20.6 \mathrm{mmol})$ was degassed in $10 \mathrm{~mL}$ of dry ether and transferred via cannula to the phosphine solution. The yellow solution was stirred for $12 \mathrm{~h}$ after which it was orange. It was filtered through Celite, and the plug was washed with dichloromethane. Water $(100 \mathrm{~mL})$ and dichloromethane $(100 \mathrm{~mL})$ were added and the organic layer was separated, washed with $100 \mathrm{~mL}$ of brine, and dried. The solvent was removed to yield $4.2 \mathrm{~g}$ of an orange oil. Column chromatography was used to isolate the product $\left(\mathrm{R}_{\mathrm{f}}=0.28\right.$, in $10 \%$ ethyl acetate/petroleum ether) as a yellow-orange oil. The oil was dissolved in dichloromethane and layered with ether and left at $0{ }^{\circ} \mathrm{C}$ overnight to give white crystals suitable for X-ray crystallography; yield was comparable to the smaller-scale reaction.

Anal. Calcd for $\mathrm{C}_{14} \mathrm{H}_{13}$ PS: C, 68.83; H, 5.36. Found: C, 68.66; H, 5.11. HRMS m/z calcd. for $\mathrm{C}_{14} \mathrm{H}_{13} \mathrm{PS}: \mathrm{m} / \mathrm{z}$ 244.0476. Found: $\mathrm{m} / \mathrm{z}$ 244.0484. ${ }^{31} \mathrm{P}\left\{{ }^{1} \mathrm{H}\right\} \mathrm{NMR}\left(\mathrm{CDCl}_{3}\right): \delta$ 58.7. ${ }^{1} \mathrm{H} \mathrm{NMR}$ $\left(\mathrm{CDCl}_{3}\right): \delta$ 7.70-7.65 (m, 3H, Ar), 7.54-7.47 (m, 2H, Ar), 7.44-7.39 (m, 4H, Ar), 3.49-3.41 (m, 1H), 3.31-3.25 (m, 1H), 2.79-2.72 (m, 1H), 2.67-2.58 (m, 1H). ${ }^{13} \mathrm{C}\left\{{ }^{1} \mathrm{H}\right\}$ NMR $\left(\mathrm{CDCl}_{3}\right): \delta 147.0(\mathrm{~d}, \mathrm{~J}=$ 28, Ar q), $134.6(\mathrm{~d}, \mathrm{~J}=87, \operatorname{Ar} q), 133.7(\mathrm{~d}, \mathrm{~J}=76, \operatorname{Ar} \mathrm{q}), 132.5(\mathrm{~d}, \mathrm{~J}=3, \operatorname{Ar}), 131.8(\mathrm{~d}, \mathrm{~J}=3, \operatorname{Ar})$, $130.9(\mathrm{~d}, \mathrm{~J}=11, \operatorname{Ar}), 129.3$ (d, J = 11, Ar), 128.8 (d, J = 12, Ar), 128.7 (d, J = 11, Ar), 126.2 (d, J = 11, Ar), 35.0 (d, J = 57), $30.2(\mathrm{~d}, \mathrm{~J}=1)$.

Pd-catalyzed Asymmetric Cyclization of Phosphine-Borane 8a (Table 2) A solution of 8a (50 mg, $\left.1.41 \times 10^{-4} \mathrm{~mol}\right)$ in THF $(0.5 \mathrm{~mL})$ was added to a solution of the catalyst precursor $\left(\operatorname{Pd}\left(\right.\right.$ diphos $\left.^{*}\right)($ trans-stilbene $\left.), 5 \mathrm{~mol} \%\right)$ in a few drops of THF. On addition of the phosphineborane the solution turned from dark yellow to a pale orange color. Proton sponge (32 mg, $1.48 \mathrm{x}$ 
$\left.10^{-4} \mathrm{~mol}\right)$ in THF ( $1 \mathrm{~mL}$ ) was then added to the solution; no further color change was observed. The mixture was transferred to an NMR tube, then monitored periodically by ${ }^{31} \mathrm{P}\left\{{ }^{1} \mathrm{H}\right\} \mathrm{NMR}$ spectroscopy. Crystals of protonated proton sponge formed after about $30 \mathrm{~min}$ at room temperature. After several days a few gas bubbles were also observed in the solution. When the reaction was complete the mixture was filtered in air to remove the base $\bullet \mathrm{HI}$ adduct and the residue was washed with additional THF $(5 \mathrm{~mL})$; the orange solution was then pumped to dryness. Column chromatography of the residue on silica eluting with ethyl acetate $(10 \%)$ /hexanes yielded pure phosphine-borane 11a $\left(\mathrm{R}_{\mathrm{f}}=0.31\right)$ as a colorless oily solid. Yields are reported in Table 2.

Effect of Added $\mathrm{BH}_{3}\left(\mathrm{SMe}_{2}\right)$ on $\mathrm{Pd}((\boldsymbol{R}, R)$-Me-DuPhos $)$-catalyzed Cyclization of 8a A solution of $8 \mathbf{a}\left(50 \mathrm{mg}, 1.41 \times 10^{-4} \mathrm{~mol}\right)$ in THF $(0.5 \mathrm{~mL})$ was charged to a NMR tube and $\mathrm{BH}_{3}\left(\mathrm{SMe}_{2}\right)\left(2.0 \mathrm{M}\right.$ in THF, $\left.70 \mu \mathrm{L}, 1.40 \mathrm{x} 10^{-4} \mathrm{~mol}\right)$ was added via syringe. A solution of the catalyst precursor $\operatorname{Pd}((R, R)-\mathrm{Me}-\mathrm{DuPhos})($ trans-stilbene) $(4 \mathrm{mg}, 0.007 \mathrm{mmol}, 5 \mathrm{~mol} \%)$ in a few drops of THF was added, turning the solution yellow. Then proton sponge ( $\left.32 \mathrm{mg}, 1.48 \times 10^{-4} \mathrm{~mol}\right)$ dissolved in $0.5 \mathrm{~mL}$ of $\mathrm{THF}$ was added. The reaction mixture was then monitored periodically by ${ }^{31} \mathrm{P}\left\{{ }^{1} \mathrm{H}\right\}$ NMR spectroscopy. After $11 \mathrm{~d}$, the solution remained yellow with no visible salt formation. Only a trace (ca. 5\%, by ${ }^{31} \mathrm{P}$ NMR integration) of cyclized product was observed; the major P-containing compound was starting material 8a. Note: in a control experiment, treatment of proton sponge $\left(30 \mathrm{mg}, 1.40 \times 10^{-4} \mathrm{~mol}\right)$ with $\mathrm{BH}_{3}\left(\mathrm{SMe}_{2}\right)(70 \mu \mathrm{L}$ of a $2.0 \mathrm{M}$ solution in $\mathrm{THF}, 1.40$ $\left.\mathrm{x} 10^{-4} \mathrm{~mol}\right)$ in $1 \mathrm{~mL}$ of $\mathrm{THF}-\mathrm{d}_{8}$ led to minimal reaction $(7 \%$ of a new proton-sponge containing species, by ${ }^{1} \mathrm{H}$ NMR integration) after $11 \mathrm{~d}$.

Ee determination for 11a: Under $\mathrm{N}_{2}$, phosphine-borane 11a was treated with $\mathrm{NEt}_{2} \mathrm{H}$ (10 equiv) or DABCO (1.2 equiv) as a solution in toluene $(1 \mathrm{~mL})$. The flask was sealed and heated at $50{ }^{\circ} \mathrm{C}$ $\left(\mathrm{NEt}_{2} \mathrm{H}\right)$ or $80^{\circ} \mathrm{C}(\mathrm{DABCO})$ for $2 \mathrm{~h}$. All volatiles were then removed in vacuo. The residue was dissolved in petroleum ether $(1 \mathrm{~mL})$ in the glovebox and passed through a column of silica, eluting with petroleum ether $(15 \mathrm{~mL})$. The solvent was then removed in vacuo to yield phosphine 10a, whose ee was determined by NMR spectroscopy according to the procedure described above. 
Formation of Racemic 11a by Pd-catalyzed Cyclization of 8a. Under $\mathrm{N}_{2}$, phosphineborane $8 \mathbf{a}(3.0 \mathrm{~g}, 8.5 \mathrm{mmol})$ was dissolved in $10 \mathrm{~mL}$ of THF. $\mathrm{NaOSiMe}_{3}(8.9 \mathrm{~mL}$ of $1.0 \mathrm{M} \mathrm{THF}$ solution, $8.9 \mathrm{mmol})$, and the catalyst precursor $\mathrm{Pd}(\mathrm{dba})_{2}(244 \mathrm{mg}, 0.425 \mathrm{mmol}, 5 \mathrm{~mol} \%)$ were added and the solution was stirred for $24 \mathrm{~h}$. The mixture was filtered through Celite. The volatile materials were removed under vacuum to give a brown oil. ${ }^{31} \mathrm{P}$ NMR spectroscopy (toluene) showed the desired product, plus impurities at $\delta 26.2$ (major impurity) and 17.2. The oil was loaded on a silica column with minimal $\mathrm{CH}_{2} \mathrm{Cl}_{2}$, and the product $(1.1 \mathrm{~g}, 58 \%$ yield $)$ was isolated as a colorless oil by dry column flash chromatography eluting with $10 \%$ ethyl acetate/hexane.

\section{Synthesis of 13 by Deprotonation/methylation of Phosphine-Borane 11a}

13

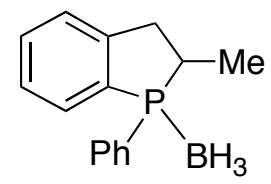

A solution of $11 \mathrm{a}(110 \mathrm{mg}, 0.49 \mathrm{mmol})$ in $20 \mathrm{~mL}$ of ether was cooled to $-78{ }^{\circ} \mathrm{C}$. Sec-butyl lithium (1.0 mL of 1.4 M solution in cyclohexane, $1.4 \mathrm{mmol}, 3$ equiv) was added dropwise and the solution turned yellow. The mixture was stirred for $1 \mathrm{~h}$ at $-78^{\circ} \mathrm{C}$ before $\mathrm{MeI}(0.3 \mathrm{~mL}, 4.9 \mathrm{mmol}, 10$ equiv) was added via a syringe. The solution was stirred at $-78{ }^{\circ} \mathrm{C}$ for $1 \mathrm{~h}$; the yellow color faded. The colorless solution was then warmed to room temperature. Water $(30 \mathrm{~mL})$ and ether $(30 \mathrm{~mL})$ were added, and the layers were separated. The aqueous layer was extracted with $2 \times 15 \mathrm{~mL}$ of ether and combined with the first organic fraction. The ether phase was washed with $30 \mathrm{~mL}$ of brine, dried with magnesium sulfate and concentrated to give $100 \mathrm{mg}$ of a colorless oil that contained two diastereomers in a 7:1 ratio $(75 \% \mathrm{de})$ according to integration of the ${ }^{1} \mathrm{H}$ and ${ }^{31} \mathrm{P}$ NMR spectra. Column chromatography eluting with 5\% ethyl acetate/hexanes gave a colorless oil which was then recrystallized from petroleum ether at $-10{ }^{\circ} \mathrm{C}$ to give diastereomerically pure white needles of the major diastereomer ( $75 \mathrm{mg}, 64 \%$ yield $)$.

Anal. Calcd for $\mathrm{C}_{15} \mathrm{H}_{18}$ BP: C, 75.04; H, 7.56. Found: C, 75.12; H, 7.66. HRMS m/z calcd. for $\mathrm{C}_{15} \mathrm{H}_{17} \mathrm{BP}(\mathrm{M}-\mathrm{H})^{+}:$239.1161. Found: $\mathrm{m} / \mathrm{z} 239.1155 .{ }^{31} \mathrm{P}\left\{{ }^{1} \mathrm{H}\right\} \mathrm{NMR}\left(\mathrm{CDCl}_{3}\right): \delta 45.6$ (br apparent $\mathrm{d}, \mathrm{J}=60) .{ }^{1} \mathrm{H}$ NMR $\left(\mathrm{CDCl}_{3}\right): \delta$ 7.58-7.52 (m, 3H, Ar), 7.50-7.47 (m, 2H, Ar), 7.43-7.35 (m, 4H, 
Ar), 3.51-3.44 (m, $\left.\mathrm{J}_{\mathrm{PH}}=11, \mathrm{~J}_{\mathrm{HH}}=16,8,1 \mathrm{H}\right), 3.01-2.95\left(\mathrm{~m}, \mathrm{~J}_{\mathrm{PH}}=7, \mathrm{~J}_{\mathrm{HH}}=16,6.3,1 \mathrm{H}\right), 2.76-2.70$ $\left(\mathrm{m}, \mathrm{J}_{\mathrm{PH}}=10.5, \mathrm{~J}_{\mathrm{HH}}=8,6.3,7.2,1 \mathrm{H}\right), 1.37\left(\mathrm{dd}, \mathrm{J}_{\mathrm{PH}}=17, \mathrm{~J}_{\mathrm{HH}}=7,3 \mathrm{H}\right), 1.4-0.4\left(\right.$ br m, 3H, $\left.\mathrm{BH}_{3}\right)$. ${ }^{13} \mathrm{C}\left\{{ }^{1} \mathrm{H}\right\} \operatorname{NMR}\left(\mathrm{CDCl}_{3}\right): \delta 147.8(\mathrm{~d}, \mathrm{~J}=15, \mathrm{Ar} q), 132.2(\mathrm{~d}, \mathrm{~J}=10, \mathrm{Ar}), 131.8(\mathrm{~d}, \mathrm{~J}=2$, Ar), 131.5 (d, J = 2, Ar), 131.0 (d, J = 40, Ar q), 130.7 (d, J = 10, Ar), 130.4 (Ar q), 129.0 (d, J = 10, Ar), 128.2 (d, J = 9, Ar), 125.9 (d, J = 8, Ar), $40.6\left(\mathrm{CH}_{2}\right), 34.9$ (d, J = 37, CHMe), 15.3 (d, J = 5, Me).

The minor diastereomer was not obtained in pure form, but it could be characterized by NMR spectroscopy of the reaction mixture. ${ }^{31} \mathrm{P}\left\{{ }^{1} \mathrm{H}\right\}$ NMR $\left(\mathrm{CDCl}_{3}\right): \delta 34.1-33.6(\mathrm{br} \mathrm{m}) .{ }^{11}$ Selected ${ }^{1} \mathrm{H}$ NMR $\left(\mathrm{CDCl}_{3}\right)$ (the aryl resonances of the two diastereomers overlapped): $\delta 3.43-3.34\left(\mathrm{~m}, \mathrm{~J}_{\mathrm{PH}}=\right.$ $\left.11, \mathrm{~J}_{\mathrm{HH}}=16,8,1 \mathrm{H}\right), 2.95-2.90\left(\mathrm{~m}, \mathrm{~J}_{\mathrm{PH}}=7, \mathrm{~J}_{\mathrm{HH}}=16,10,1 \mathrm{H}\right), 2.67-2.61\left(\mathrm{~m}, \mathrm{~J}_{\mathrm{PH}}=10.5, \mathrm{~J}_{\mathrm{HH}}=10,8\right.$, $7.2,1 \mathrm{H}), 1.37\left(\mathrm{dd}, \mathrm{J}_{\mathrm{PH}}=15, \mathrm{~J}_{\mathrm{HH}}=7.2,3 \mathrm{H}\right)$.

Stereochemistry of Deprotonation/Methylation The trans stereochemistry of the P-Ph and $\mathrm{C}-\mathrm{Me}$ groups in $\mathbf{1 3}$ was determined by X-ray crystallography on diastereomerically pure $\mathbf{1 3}$. These results were consistent with NMR studies. The ${ }^{1} \mathrm{H}$ NMR assignments in Figure S2 were made using DEPT, C-H correlation, H-H correlation, and 1D-NOE Experiments.

Figure S2. Selected ${ }^{1} \mathrm{H}$ NMR Data $\left(\mathrm{CDCl}_{3}\right)$ for the major diastereomer of 13, and Important NOEs Observed
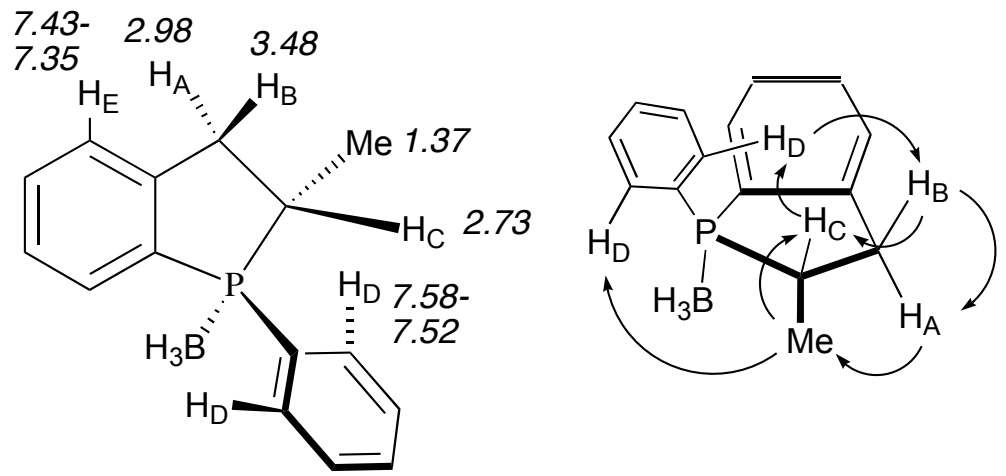

Assignment of the trans stereochemistry of the $\mathrm{Me}$ and $\mathrm{P}-\mathrm{Ph}$ groups was consistent with these observations:

1. The Me group showed a strong NOE to $H_{A}$, but only a weak one to $H_{B}$, which suggests $H_{A}$ and $\mathrm{Me}$ are cis. 
2. $H_{C}$ showed a strong $N O E$ to $H_{B}$, but a weak one to $H_{A}$, suggesting that $H_{B}$ and $H_{C}$ are cis.

3. $\mathrm{H}_{\mathrm{B}}$, but not $\mathrm{H}_{\mathrm{A}}$, showed an NOE to $\mathrm{H}_{\mathrm{D}}$, suggesting a cis relationship between these hydrogens.

Table S2. Summary of 1D-NOESY Data for the major diastereomer of $\mathbf{1 3}\left(\mathrm{CDCl}_{3}\right)^{\mathrm{a}}$

\begin{tabular}{|l|l|}
\hline Signal & NOE (in order of intensity) \\
\hline $1.37(\mathrm{Me})$ & $2.73\left(\mathrm{H}_{\mathrm{C}}\right)>2.98\left(\mathrm{H}_{\mathrm{A}}\right)>7.58-7.52\left(\mathrm{H}_{\mathrm{D}}\right)$ \\
\hline $2.73\left(\mathrm{H}_{\mathrm{C}}\right)$ & $1.37(\mathrm{Me})>7.58-7.52\left(\mathrm{H}_{\mathrm{D}}\right)>3.48\left(\mathrm{H}_{\mathrm{B}}\right)>2.98\left(\mathrm{H}_{\mathrm{A}}\right)$ \\
\hline $2.98\left(\mathrm{H}_{\mathrm{A}}\right)$ & $3.48\left(\mathrm{H}_{\mathrm{B}}\right)>1.37(\mathrm{Me})>7.43-7.35\left(\mathrm{H}_{\mathrm{E}}\right)>2.73\left(\mathrm{H}_{\mathrm{C}}\right)$ \\
\hline $3.48\left(\mathrm{H}_{\mathrm{B}}\right)$ & $2.98\left(\mathrm{H}_{\mathrm{A}}\right)>7.43-7.35\left(\mathrm{H}_{\mathrm{E}}\right)>2.73\left(\mathrm{H}_{\mathrm{C}}\right)>7.58-7.52\left(\mathrm{H}_{\mathrm{D}}\right)>1.37(\mathrm{Me})$ \\
\hline
\end{tabular}

${ }^{\mathrm{a}}$ For clarity, not all of these NOEs are shown in Figure S2.

Figure S3. ORTEP diagram of the benzophospholane sulfide 12.

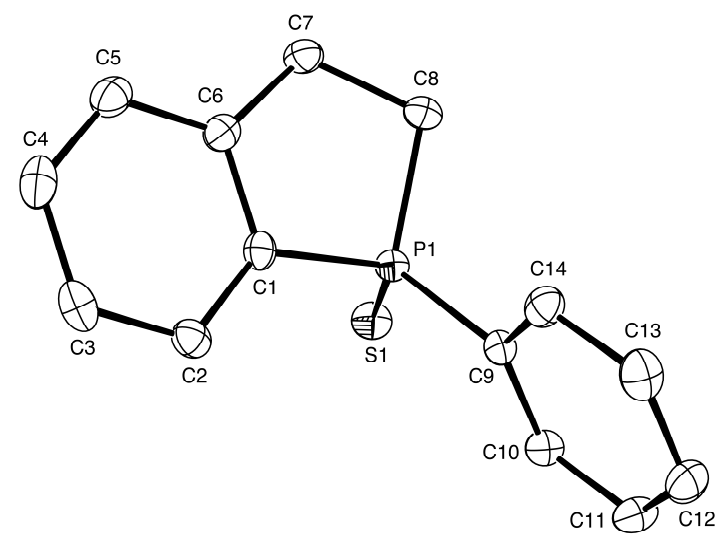


Table 1. Crystal data and structure refinement for Ph-benzophospholane sulfide, glu227 (12).

Identification code

Empirical formula

Formula weight

Temperature

Wavelength

Crystal system

Space group

Unit cell dimensions

Volume

$\mathrm{Z}$

Density (calculated)

Absorption coefficient

$\mathrm{F}(000)$

Crystal size

Theta range for data collection

Index ranges

Reflections collected

Independent reflections

Completeness to theta $=25.00^{\circ}$

Absorption correction

Max. and min. transmission

Refinement method

Data / restraints / parameters

Goodness-of-fit on $\mathrm{F}^{2}$

Final $\mathrm{R}$ indices $[\mathrm{I}>2 \operatorname{sigma}(\mathrm{I})]$

$\mathrm{R}$ indices (all data)

Absolute structure parameter

Largest diff. peak and hole glu227

C14 H13 P S

244.27

208(2) K

$0.71073 \AA$

Monoclinic

P2(1)

$$
\begin{array}{ll}
\mathrm{a}=8.3368(16) \AA & \alpha=90^{\circ} \\
\mathrm{b}=9.1981(17) \AA & \beta=115.081(3)^{\circ} \\
\mathrm{c}=8.8279(17) \AA & \gamma=90^{\circ}
\end{array}
$$

613.1(2) $\AA^{3}$

2

$1.323 \mathrm{~g} / \mathrm{cm}^{3}$

$0.362 \mathrm{~mm}^{-1}$

256

$0.41 \times 0.37 \times 0.21 \mathrm{~mm}^{3}$

2.55 to $28.33^{\circ}$

$-11<=\mathrm{h}<=10,-11<=\mathrm{k}<=11,-11<=\mathrm{l}<=11$

4124

$2289[\mathrm{R}(\mathrm{int})=0.0266]$

$98.7 \%$

Semi-empirical from equivalents

0.943 and 0.887

Full-matrix least-squares on $\mathrm{F}^{2}$

$2289 / 1 / 145$

1.163

$\mathrm{R} 1=0.0339, \mathrm{wR} 2=0.0845$

$\mathrm{R} 1=0.0344, \mathrm{wR} 2=0.0850$

$0.01(7)$

0.578 and -0.183 e $\AA^{-3}$ 
Table 2. Atomic coordinates $\left(\mathrm{x} 10^{4}\right)$ and equivalent isotropic displacement parameters $\left(\AA^{2} \times 10^{3}\right)$ for $\mathrm{Ph}$ benzophospholane sulfide, glu227. $\mathrm{U}(\mathrm{eq})$ is defined as one third of the trace of the orthogonalized $\mathrm{U}^{\mathrm{ij}}$ tensor.

\begin{tabular}{|c|c|c|c|c|}
\hline & $\mathrm{x}$ & $\mathrm{y}$ & $\mathrm{z}$ & $\mathrm{U}(\mathrm{eq})$ \\
\hline$S(1)$ & $8197(1)$ & $9610(1)$ & $2354(1)$ & $37(1)$ \\
\hline $\mathrm{P}(1)$ & $6645(1)$ & 7914(1) & $1637(1)$ & $26(1)$ \\
\hline $\mathrm{C}(1)$ & $7726(3)$ & $6200(2)$ & 1764(3) & $27(1)$ \\
\hline$C(2)$ & $8605(3)$ & $5312(3)$ & $3147(3)$ & $32(1)$ \\
\hline$C(3)$ & $9338(3)$ & 4013(2) & 2941(3) & $37(1)$ \\
\hline $\mathrm{C}(4)$ & $9222(3)$ & $3638(3)$ & 1384(3) & $40(1)$ \\
\hline$C(5)$ & $8390(3)$ & $4538(3)$ & $7(3)$ & $37(1)$ \\
\hline$C(6)$ & $7608(2)$ & $5823(2)$ & $189(3)$ & $30(1)$ \\
\hline$C(7)$ & $6577(3)$ & $6875(3)$ & $-1187(3)$ & $35(1)$ \\
\hline $\mathrm{C}(8)$ & $5363(3)$ & $7742(2)$ & $-608(2)$ & $31(1)$ \\
\hline $\mathrm{C}(9)$ & $5196(2)$ & $7719(2)$ & $2682(2)$ & $27(1)$ \\
\hline $\mathrm{C}(10)$ & $5397(3)$ & $8630(3)$ & 3994(3) & $34(1)$ \\
\hline $\mathrm{C}(11)$ & $4249(3)$ & $8495(3)$ & $4759(3)$ & $41(1)$ \\
\hline $\mathrm{C}(12)$ & $2926(3)$ & $7466(3)$ & $4209(3)$ & $42(1)$ \\
\hline $\mathrm{C}(13)$ & $2736(3)$ & $6555(3)$ & 2915(3) & $38(1)$ \\
\hline$C(14)$ & $3862(3)$ & $6670(2)$ & $2142(3)$ & $32(1)$ \\
\hline
\end{tabular}


Table 3. Bond lengths $[\AA ̊]$ and angles [deg] for Ph-benzophospholane sulfide, glu227.

\begin{tabular}{|c|c|c|c|}
\hline $\mathrm{S}(1)-\mathrm{P}(1)$ & $1.9531(7)$ & $\mathrm{C}(6)-\mathrm{C}(7)$ & $1.505(3)$ \\
\hline $\mathrm{P}(1)-\mathrm{C}(1)$ & $1.796(2)$ & $\mathrm{C}(7)-\mathrm{C}(8)$ & $1.536(3)$ \\
\hline $\mathrm{P}(1)-\mathrm{C}(9)$ & $1.813(2)$ & $\mathrm{C}(9)-\mathrm{C}(10)$ & $1.381(3)$ \\
\hline $\mathrm{P}(1)-\mathrm{C}(8)$ & $1.816(2)$ & $\mathrm{C}(9)-\mathrm{C}(14)$ & $1.395(3)$ \\
\hline $\mathrm{C}(1)-\mathrm{C}(2)$ & $1.392(3)$ & $\mathrm{C}(10)-\mathrm{C}(11)$ & $1.391(3)$ \\
\hline $\mathrm{C}(1)-\mathrm{C}(6)$ & $1.395(3)$ & $\mathrm{C}(11)-\mathrm{C}(12)$ & $1.376(4)$ \\
\hline$C(2)-C(3)$ & $1.388(3)$ & $\mathrm{C}(12)-\mathrm{C}(13)$ & $1.370(3)$ \\
\hline $\mathrm{C}(3)-\mathrm{C}(4)$ & $1.380(4)$ & $\mathrm{C}(13)-\mathrm{C}(14)$ & $1.379(3)$ \\
\hline$C(4)-C(5)$ & $1.389(3)$ & & \\
\hline$C(5)-C(6)$ & $1.392(3)$ & & \\
\hline $\mathrm{C}(1)-\mathrm{P}(1)-\mathrm{C}(9)$ & $107.84(9)$ & $\mathrm{C}(10)-\mathrm{C}(9)-\mathrm{C}(14)$ & $120.09(19)$ \\
\hline $\mathrm{C}(1)-\mathrm{P}(1)-\mathrm{C}(8)$ & $92.25(10)$ & $\mathrm{C}(10)-\mathrm{C}(9)-\mathrm{P}(1)$ & $119.79(16)$ \\
\hline $\mathrm{C}(9)-\mathrm{P}(1)-\mathrm{C}(8)$ & 109.64(9) & $\mathrm{C}(14)-\mathrm{C}(9)-\mathrm{P}(1)$ & $120.11(15)$ \\
\hline $\mathrm{C}(1)-\mathrm{P}(1)-\mathrm{S}(1)$ & $115.76(7)$ & $\mathrm{C}(9)-\mathrm{C}(10)-\mathrm{C}(11)$ & $119.3(2)$ \\
\hline $\mathrm{C}(9)-\mathrm{P}(1)-\mathrm{S}(1)$ & $114.02(7)$ & $\mathrm{C}(12)-\mathrm{C}(11)-\mathrm{C}(10)$ & $120.3(2)$ \\
\hline $\mathrm{C}(8)-\mathrm{P}(1)-\mathrm{S}(1)$ & $115.21(8)$ & $\mathrm{C}(13)-\mathrm{C}(12)-\mathrm{C}(11)$ & $120.4(2)$ \\
\hline $\mathrm{C}(2)-\mathrm{C}(1)-\mathrm{C}(6)$ & 121.1(2) & $\mathrm{C}(12)-\mathrm{C}(13)-\mathrm{C}(14)$ & $120.2(2)$ \\
\hline $\mathrm{C}(2)-\mathrm{C}(1)-\mathrm{P}(1)$ & $129.35(18)$ & $\mathrm{C}(13)-\mathrm{C}(14)-\mathrm{C}(9)$ & $119.7(2)$ \\
\hline $\mathrm{C}(6)-\mathrm{C}(1)-\mathrm{P}(1)$ & $109.52(15)$ & & \\
\hline $\mathrm{C}(3)-\mathrm{C}(2)-\mathrm{C}(1)$ & 119.2(2) & & \\
\hline $\mathrm{C}(4)-\mathrm{C}(3)-\mathrm{C}(2)$ & $119.8(2)$ & & \\
\hline $\mathrm{C}(3)-\mathrm{C}(4)-\mathrm{C}(5)$ & $121.4(2)$ & & \\
\hline $\mathrm{C}(4)-\mathrm{C}(5)-\mathrm{C}(6)$ & $119.3(2)$ & & \\
\hline $\mathrm{C}(5)-\mathrm{C}(6)-\mathrm{C}(1)$ & $119.18(19)$ & & \\
\hline $\mathrm{C}(5)-\mathrm{C}(6)-\mathrm{C}(7)$ & $126.0(2)$ & & \\
\hline $\mathrm{C}(1)-\mathrm{C}(6)-\mathrm{C}(7)$ & $114.80(18)$ & & \\
\hline $\mathrm{C}(6)-\mathrm{C}(7)-\mathrm{C}(8)$ & $107.24(17)$ & & \\
\hline $\mathrm{C}(7)-\mathrm{C}(8)-\mathrm{P}(1)$ & $104.04(13)$ & & \\
\hline
\end{tabular}


Table 4. Anisotropic displacement parameters $\left(\AA^{2} \times 10^{3}\right)$ for Ph-benzophospholane sulfide, glu227. The anisotropic displacement factor exponent takes the form: $-2 \pi^{2}\left[h^{2} a^{* 2} U^{11}+\ldots+2 h k a^{*} b^{*} U^{12}\right]$

\begin{tabular}{|c|c|c|c|c|c|c|}
\hline & $\mathrm{U}^{11}$ & $\mathrm{U}^{22}$ & $\mathrm{U}^{33}$ & $\mathrm{U}^{23}$ & $\mathrm{U}^{13}$ & $\mathrm{U}^{12}$ \\
\hline$S(1)$ & $38(1)$ & $33(1)$ & $39(1)$ & $-3(1)$ & $15(1)$ & $-10(1)$ \\
\hline $\mathrm{P}(1)$ & $27(1)$ & $26(1)$ & $25(1)$ & $0(1)$ & 11(1) & $-1(1)$ \\
\hline $\mathrm{C}(1)$ & $23(1)$ & $27(1)$ & $33(1)$ & $0(1)$ & $13(1)$ & $0(1)$ \\
\hline$C(2)$ & $27(1)$ & $38(1)$ & $31(1)$ & $3(1)$ & 11(1) & $-2(1)$ \\
\hline$C(3)$ & $26(1)$ & $34(1)$ & $47(1)$ & $9(1)$ & 11(1) & $2(1)$ \\
\hline $\mathrm{C}(4)$ & $29(1)$ & $32(1)$ & $59(2)$ & $-7(1)$ & $19(1)$ & $1(1)$ \\
\hline$C(5)$ & $31(1)$ & $43(1)$ & $39(1)$ & $-13(1)$ & $16(1)$ & $-6(1)$ \\
\hline$C(6)$ & $27(1)$ & $32(1)$ & $34(1)$ & $-6(1)$ & $15(1)$ & $-6(1)$ \\
\hline$C(7)$ & $36(1)$ & $45(1)$ & $27(1)$ & $-1(1)$ & $16(1)$ & $0(1)$ \\
\hline $\mathrm{C}(8)$ & $33(1)$ & $34(1)$ & $25(1)$ & $2(1)$ & $10(1)$ & $-1(1)$ \\
\hline $\mathrm{C}(9)$ & $25(1)$ & $28(1)$ & $27(1)$ & $2(1)$ & $10(1)$ & $3(1)$ \\
\hline$C(10)$ & $35(1)$ & $37(1)$ & $29(1)$ & $-1(1)$ & $13(1)$ & 2(1) \\
\hline$C(11)$ & $49(1)$ & $50(1)$ & $29(1)$ & $-2(1)$ & $20(1)$ & $3(1)$ \\
\hline $\mathrm{C}(12)$ & $42(1)$ & $55(1)$ & $39(1)$ & $8(1)$ & $26(1)$ & $6(1)$ \\
\hline $\mathrm{C}(13)$ & $34(1)$ & $35(1)$ & $48(1)$ & $6(1)$ & $19(1)$ & $-2(1)$ \\
\hline $\mathrm{C}(14)$ & $37(1)$ & $28(1)$ & $34(1)$ & $0(1)$ & $18(1)$ & $3(1)$ \\
\hline
\end{tabular}


Table 5. Hydrogen coordinates $\left(\times 10^{4}\right)$ and isotropic displacement parameters $\left(\AA^{2} \times 10^{3}\right)$ for Ph-benzophospholane sulfide, glu227.

\begin{tabular}{|c|c|c|c|c|}
\hline & $\mathrm{x}$ & $\mathrm{y}$ & z & $\mathrm{U}(\mathrm{eq})$ \\
\hline $\mathrm{H}(2 \mathrm{~A})$ & 8699 & 5584 & 4196 & 39 \\
\hline $\mathrm{H}(3 \mathrm{~A})$ & 9905 & 3398 & 3849 & 45 \\
\hline $\mathrm{H}(4 \mathrm{~A})$ & 9710 & 2764 & 1254 & 48 \\
\hline $\mathrm{H}(5 \mathrm{~A})$ & 8356 & 4284 & -1026 & 45 \\
\hline $\mathrm{H}(7 \mathrm{~A})$ & 5878 & 6354 & -2211 & 42 \\
\hline $\mathrm{H}(7 \mathrm{~B})$ & 7377 & 7525 & -1396 & 42 \\
\hline $\mathrm{H}(8 \mathrm{~A})$ & 4265 & 7224 & -864 & 38 \\
\hline $\mathrm{H}(8 \mathrm{~B})$ & 5092 & 8690 & -1138 & 38 \\
\hline $\mathrm{H}(10 \mathrm{~A})$ & 6290 & 9326 & 4363 & 41 \\
\hline $\mathrm{H}(11 \mathrm{~A})$ & 4376 & 9102 & 5645 & 49 \\
\hline $\mathrm{H}(12 \mathrm{~A})$ & 2156 & 7388 & 4719 & 51 \\
\hline $\mathrm{H}(13 \mathrm{~A})$ & 1845 & 5858 & 2558 & 46 \\
\hline $\mathrm{H}(14 \mathrm{~A})$ & 3732 & 6051 & 1265 & 38 \\
\hline
\end{tabular}

Figure S4. ORTEP diagram of methylated benzophospholane-borane 13.

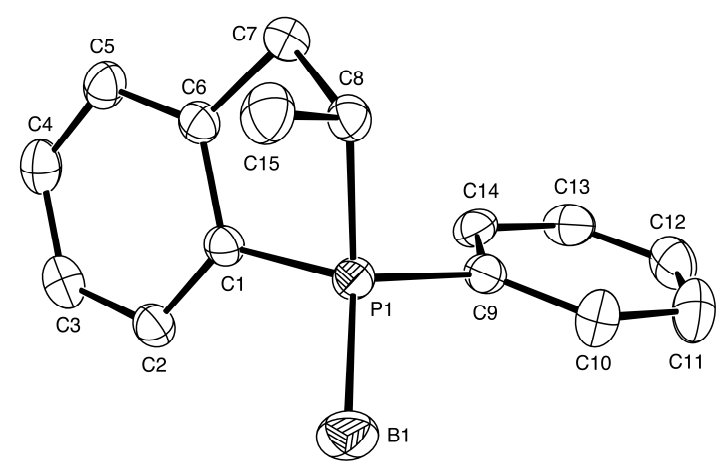


Table 1. Crystal data and structure refinement for methylated Ph-benzophospholane-borane, glu244 (13).

Identification code

Empirical formula

Formula weight

Temperature

Wavelength

Crystal system

Space group

Unit cell dimensions

Volume

Z

Density (calculated)

Absorption coefficient

$\mathrm{F}(000)$

Crystal size

Theta range for data collection

Index ranges

Reflections collected

Independent reflections

Completeness to theta $=25.00^{\circ}$

Absorption correction

Max. and min. transmission

Refinement method

Data / restraints / parameters

Goodness-of-fit on $\mathrm{F}^{2}$

Final $\mathrm{R}$ indices [I $>2 \operatorname{sigma}(\mathrm{I})]$

$\mathrm{R}$ indices (all data)

Absolute structure parameter

Largest diff. peak and hole glu244

C15 H18 B P

240.07

208(2) K

$0.71073 \AA$

Orthorhombic

P2(1)2(1)2(1)

$a=9.4071(12) \AA$

$\alpha=90^{\circ}$

$\mathrm{b}=11.3293(16) \AA$

$\beta=90^{\circ}$

$c=12.9898(16) \AA$

$\gamma=90^{\circ}$
4

$1.152 \mathrm{~g} / \mathrm{cm}^{3}$

$0.173 \mathrm{~mm}^{-1}$

512

$0.30 \times 0.12 \times 0.08 \mathrm{~mm}^{3}$

2.67 to $28.22^{\circ}$

$-1<=\mathrm{h}<=12,-13<=\mathrm{k}<=12,-7<=\mathrm{l}<=15$

3698

$2448[\mathrm{R}(\mathrm{int})=0.0173]$

$98.4 \%$

multi-scan

0.9863 and 0.9498

Full-matrix least-squares on $\mathrm{F}^{2}$

2448 / 0 / 166

1.030

$\mathrm{R} 1=0.0424, \mathrm{wR} 2=0.1092$

$\mathrm{R} 1=0.0477, \mathrm{wR} 2=0.1129$

$-0.19(14)$

0.243 and -0.219 e $\AA^{-3}$ 
Table 2. Atomic coordinates $\left(\mathrm{x} 10^{4}\right)$ and equivalent isotropic displacement parameters $\left(\AA^{2} \times 10^{3}\right)$ for methylated $\mathrm{Ph}$ benzophospholane-borane, glu244. $\mathrm{U}(\mathrm{eq})$ is defined as one third of the trace of the orthogonalized $\mathrm{U}^{\mathrm{ij}}$ tensor.

\begin{tabular}{|c|c|c|c|c|}
\hline & $\mathrm{x}$ & $\mathrm{y}$ & $\mathrm{z}$ & $\mathrm{U}(\mathrm{eq})$ \\
\hline $\mathrm{P}(1)$ & $7535(1)$ & 2304(1) & 1918(1) & $36(1)$ \\
\hline $\mathrm{C}(1)$ & $7851(2)$ & $3446(3)$ & $1007(2)$ & $35(1)$ \\
\hline$C(2)$ & $8562(2)$ & $4522(3)$ & $1154(2)$ & $42(1)$ \\
\hline$C(3)$ & $8769(2)$ & $5259(3)$ & $319(3)$ & $51(1)$ \\
\hline$C(4)$ & $8270(3)$ & 4943(3) & $-636(3)$ & $52(1)$ \\
\hline$C(7)$ & $6610(2)$ & 1949(3) & $0(2)$ & $44(1)$ \\
\hline$C(8)$ & $7173(2)$ & 1211(3) & $913(2)$ & $39(1)$ \\
\hline$C(10)$ & $5477(3)$ & 1927(3) & $3383(2)$ & $53(1)$ \\
\hline $\mathrm{C}(11)$ & $4160(3)$ & 2058(4) & $3847(3)$ & $66(1)$ \\
\hline$C(12)$ & $3204(3)$ & 2851(4) & $3457(3)$ & $59(1)$ \\
\hline $\mathrm{C}(13)$ & $3540(3)$ & $3519(4)$ & $2618(2)$ & $54(1)$ \\
\hline$C(14)$ & $4858(3)$ & 3391(3) & $2137(2)$ & $44(1)$ \\
\hline$C(15)$ & $8514(3)$ & $522(3)$ & $625(2)$ & $54(1)$ \\
\hline $\mathrm{B}(1)$ & $9009(3)$ & 1989(5) & 2897(3) & $57(1)$ \\
\hline $\mathrm{C}(9)$ & $5825(2)$ & $2578(3)$ & $2524(2)$ & $38(1)$ \\
\hline$C(5)$ & 7564(3) & $3885(3)$ & $-794(2)$ & $46(1)$ \\
\hline$C(6)$ & $7348(2)$ & $3135(3)$ & $37(2)$ & $38(1)$ \\
\hline
\end{tabular}


Table 3. Bond lengths $[\AA ̊]$ and angles [deg] for methylated Ph-benzophospholane-borane, glu244.

\begin{tabular}{|c|c|c|c|}
\hline $\mathrm{P}(1)-\mathrm{C}(1)$ & $1.779(3)$ & $\mathrm{C}(8)-\mathrm{P}(1)-\mathrm{B}(1)$ & $118.84(18)$ \\
\hline $\mathrm{P}(1)-\mathrm{C}(9)$ & $1.817(2)$ & $\mathrm{C}(6)-\mathrm{C}(1)-\mathrm{C}(2)$ & $120.3(3)$ \\
\hline $\mathrm{P}(1)-\mathrm{C}(8)$ & $1.831(3)$ & $\mathrm{C}(6)-\mathrm{C}(1)-\mathrm{P}(1)$ & $111.1(2)$ \\
\hline $\mathrm{P}(1)-\mathrm{B}(1)$ & $1.916(3)$ & $\mathrm{C}(2)-\mathrm{C}(1)-\mathrm{P}(1)$ & $128.5(2)$ \\
\hline$C(1)-C(6)$ & $1.391(3)$ & $\mathrm{C}(3)-\mathrm{C}(2)-\mathrm{C}(1)$ & $119.0(3)$ \\
\hline $\mathrm{C}(1)-\mathrm{C}(2)$ & $1.403(4)$ & $\mathrm{C}(4)-\mathrm{C}(3)-\mathrm{C}(2)$ & $120.2(3)$ \\
\hline $\mathrm{C}(2)-\mathrm{C}(3)$ & $1.382(4)$ & $\mathrm{C}(3)-\mathrm{C}(4)-\mathrm{C}(5)$ & $121.5(3)$ \\
\hline $\mathrm{C}(3)-\mathrm{C}(4)$ & $1.374(5)$ & $\mathrm{C}(6)-\mathrm{C}(7)-\mathrm{C}(8)$ & $107.4(2)$ \\
\hline $\mathrm{C}(4)-\mathrm{C}(5)$ & $1.385(4)$ & $\mathrm{C}(15)-\mathrm{C}(8)-\mathrm{C}(7)$ & $111.8(2)$ \\
\hline$C(7)-C(6)$ & $1.513(4)$ & $\mathrm{C}(15)-\mathrm{C}(8)-\mathrm{P}(1)$ & $111.47(19)$ \\
\hline$C(7)-C(8)$ & $1.545(4)$ & $\mathrm{C}(7)-\mathrm{C}(8)-\mathrm{P}(1)$ & $104.2(2)$ \\
\hline $\mathrm{C}(8)-\mathrm{C}(15)$ & $1.530(4)$ & $\mathrm{C}(9)-\mathrm{C}(10)-\mathrm{C}(11)$ & $120.6(3)$ \\
\hline $\mathrm{C}(10)-\mathrm{C}(9)$ & $1.377(4)$ & $\mathrm{C}(12)-\mathrm{C}(11)-\mathrm{C}(10)$ & 119.7(3) \\
\hline $\mathrm{C}(10)-\mathrm{C}(11)$ & $1.386(4)$ & $\mathrm{C}(13)-\mathrm{C}(12)-\mathrm{C}(11)$ & $120.5(3)$ \\
\hline$C(11)-C(12)$ & $1.368(6)$ & $\mathrm{C}(12)-\mathrm{C}(13)-\mathrm{C}(14)$ & $120.4(3)$ \\
\hline $\mathrm{C}(12)-\mathrm{C}(13)$ & $1.364(5)$ & $\mathrm{C}(9)-\mathrm{C}(14)-\mathrm{C}(13)$ & 119.2(3) \\
\hline$C(13)-C(14)$ & $1.396(4)$ & $\mathrm{C}(10)-\mathrm{C}(9)-\mathrm{C}(14)$ & $119.5(2)$ \\
\hline $\mathrm{C}(14)-\mathrm{C}(9)$ & $1.389(4)$ & $\mathrm{C}(10)-\mathrm{C}(9)-\mathrm{P}(1)$ & $118.1(2)$ \\
\hline \multirow[t]{2}{*}{$\mathrm{C}(5)-\mathrm{C}(6)$} & $1.389(4)$ & $\mathrm{C}(14)-\mathrm{C}(9)-\mathrm{P}(1)$ & $122.4(2)$ \\
\hline & & $C(4)-C(5)-C(6)$ & $119.0(3)$ \\
\hline $\mathrm{C}(1)-\mathrm{P}(1)-\mathrm{C}(9)$ & $108.18(13)$ & $C(5)-C(6)-C(1)$ & $119.9(3)$ \\
\hline $\mathrm{C}(1)-\mathrm{P}(1)-\mathrm{C}(8)$ & $92.82(14)$ & $\mathrm{C}(5)-\mathrm{C}(6)-\mathrm{C}(7)$ & $125.8(2)$ \\
\hline $\mathrm{C}(9)-\mathrm{P}(1)-\mathrm{C}(8)$ & $105.10(11)$ & $\mathrm{C}(1)-\mathrm{C}(6)-\mathrm{C}(7)$ & $114.2(3)$ \\
\hline $\mathrm{C}(1)-\mathrm{P}(1)-\mathrm{B}(1)$ & $117.14(16)$ & & \\
\hline $\mathrm{C}(9)-\mathrm{P}(1)-\mathrm{B}(1)$ & $112.57(15)$ & $\begin{array}{l}\text { Symmetry transforn } \\
\text { atoms: }\end{array}$ & 1 to genera \\
\hline
\end{tabular}


Table 4. Anisotropic displacement parameters $\left(\AA^{2} \mathrm{x} 10^{3}\right)$ for methylated Ph-benzophospholane-borane, glu244. The anisotropic displacement factor exponent takes the form: $-2 \pi^{2}\left[h^{2} a^{* 2} U^{11}+\ldots+2 h k\right.$ a* $\left.b^{*} U^{12}\right]$

\begin{tabular}{|c|c|c|c|c|c|c|}
\hline & $\mathrm{U}^{11}$ & $\mathrm{U}^{22}$ & $\mathrm{U}^{33}$ & $\mathrm{U}^{23}$ & $\mathrm{U}^{13}$ & $\mathrm{U}^{12}$ \\
\hline $\mathrm{P}(1)$ & $32(1)$ & $44(1)$ & $32(1)$ & $0(1)$ & $0(1)$ & $1(1)$ \\
\hline $\mathrm{C}(1)$ & $29(1)$ & $40(2)$ & $37(2)$ & $-4(2)$ & $2(1)$ & $0(1)$ \\
\hline $\mathrm{C}(2)$ & $36(1)$ & $47(2)$ & $45(2)$ & $-7(2)$ & 1(1) & $-3(1)$ \\
\hline $\mathrm{C}(3)$ & $42(1)$ & $44(2)$ & $67(2)$ & 2(2) & $8(1)$ & $-4(1)$ \\
\hline $\mathrm{C}(4)$ & $44(2)$ & $54(3)$ & $57(2)$ & $17(2)$ & $8(1)$ & $4(1)$ \\
\hline$C(7)$ & $41(1)$ & $52(2)$ & $39(2)$ & $-3(2)$ & $-3(1)$ & $-8(1)$ \\
\hline $\mathrm{C}(8)$ & $40(1)$ & $38(2)$ & $40(2)$ & $-1(2)$ & $4(1)$ & $-4(1)$ \\
\hline $\mathrm{C}(10)$ & $54(2)$ & $56(3)$ & $50(2)$ & $11(2)$ & $10(1)$ & $3(1)$ \\
\hline $\mathrm{C}(11)$ & $67(2)$ & $66(3)$ & $65(3)$ & $7(2)$ & $27(2)$ & $-7(2)$ \\
\hline $\mathrm{C}(12)$ & $44(2)$ & $67(3)$ & $67(2)$ & $-16(2)$ & $18(1)$ & $-3(1)$ \\
\hline $\mathrm{C}(13)$ & $41(1)$ & $67(3)$ & $52(2)$ & $-18(2)$ & $-2(1)$ & $8(1)$ \\
\hline$C(14)$ & $43(1)$ & $57(2)$ & $31(2)$ & $-5(2)$ & $0(1)$ & $3(1)$ \\
\hline$C(15)$ & $52(2)$ & $54(3)$ & $54(2)$ & $-5(2)$ & $12(1)$ & $4(1)$ \\
\hline $\mathrm{B}(1)$ & $45(2)$ & $76(3)$ & $49(2)$ & $2(2)$ & $-14(1)$ & $11(2)$ \\
\hline$C(9)$ & $34(1)$ & $42(2)$ & $36(2)$ & $-5(1)$ & $0(1)$ & $-3(1)$ \\
\hline $\mathrm{C}(5)$ & $42(1)$ & $59(2)$ & $38(2)$ & $9(1)$ & $1(1)$ & $3(1)$ \\
\hline$C(6)$ & $31(1)$ & $43(2)$ & $39(2)$ & $0(1)$ & $0(1)$ & $0(1)$ \\
\hline
\end{tabular}


Table 5. Hydrogen coordinates $\left(\begin{array}{ll}x & 10^{4}\end{array}\right)$ and isotropic displacement parameters $\left(\AA^{2} \times 10^{3}\right)$ for methylated $\mathrm{Ph}-$ benzophospholane-borane, glu244.

\begin{tabular}{|c|c|c|c|c|}
\hline & $\mathrm{x}$ & $\mathrm{y}$ & $\mathrm{z}$ & $\mathrm{U}(\mathrm{eq})$ \\
\hline $\mathrm{H}(2 \mathrm{~A})$ & 8893 & 4739 & 1810 & 51 \\
\hline $\mathrm{H}(3 \mathrm{~A})$ & 9252 & 5978 & 405 & 61 \\
\hline $\mathrm{H}(4 \mathrm{~A})$ & 8411 & 5456 & -1196 & 62 \\
\hline $\mathrm{H}(7 \mathrm{~A})$ & 6817 & 1550 & -653 & 52 \\
\hline $\mathrm{H}(7 \mathrm{~B})$ & 5579 & 2052 & 57 & 52 \\
\hline $\mathrm{H}(8 \mathrm{~A})$ & 6426 & 658 & 1150 & 47 \\
\hline $\mathrm{H}(10 \mathrm{~A})$ & 6138 & 1389 & 3656 & 64 \\
\hline $\mathrm{H}(11 \mathrm{~A})$ & 3924 & 1603 & 4428 & 79 \\
\hline $\mathrm{H}(12 \mathrm{~A})$ & 2309 & 2936 & 3770 & 71 \\
\hline $\mathrm{H}(13 \mathrm{~A})$ & 2881 & 4069 & 2363 & 64 \\
\hline $\mathrm{H}(14 \mathrm{~A})$ & 5088 & 3849 & 1557 & 52 \\
\hline $\mathrm{H}(15 \mathrm{~A})$ & 8287 & -49 & 93 & 80 \\
\hline $\mathrm{H}(15 \mathrm{~B})$ & 8874 & 115 & 1227 & 80 \\
\hline $\mathrm{H}(15 \mathrm{C})$ & 9231 & 1064 & 370 & 80 \\
\hline $\mathrm{H}(5 \mathrm{~A})$ & 7236 & 3678 & -1453 & 55 \\
\hline $\mathrm{H}(1 \mathrm{C})$ & $9050(30)$ & $2750(40)$ & $3320(30)$ & $71(12)$ \\
\hline $\mathrm{H}(1 \mathrm{~B})$ & $8640(30)$ & $1100(40)$ & $3350(30)$ & $78(12)$ \\
\hline $\mathrm{H}(1 \mathrm{~A})$ & $9970(50)$ & $1900(50)$ & $2560(40)$ & $106(13)$ \\
\hline
\end{tabular}




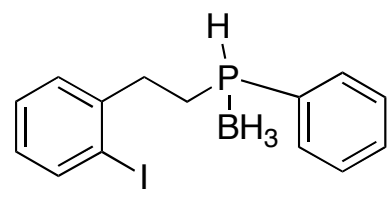

$8 a$
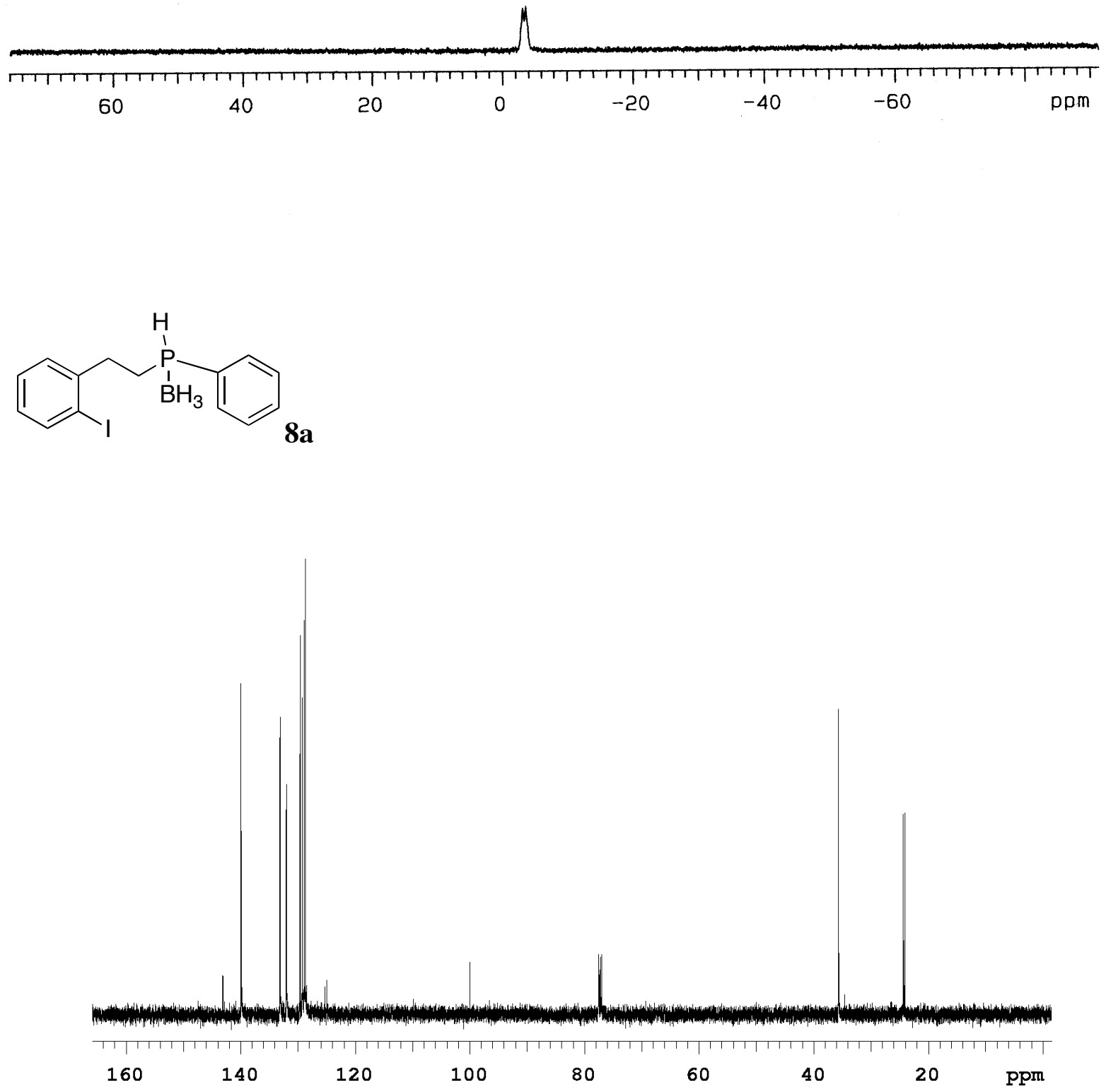

S31 

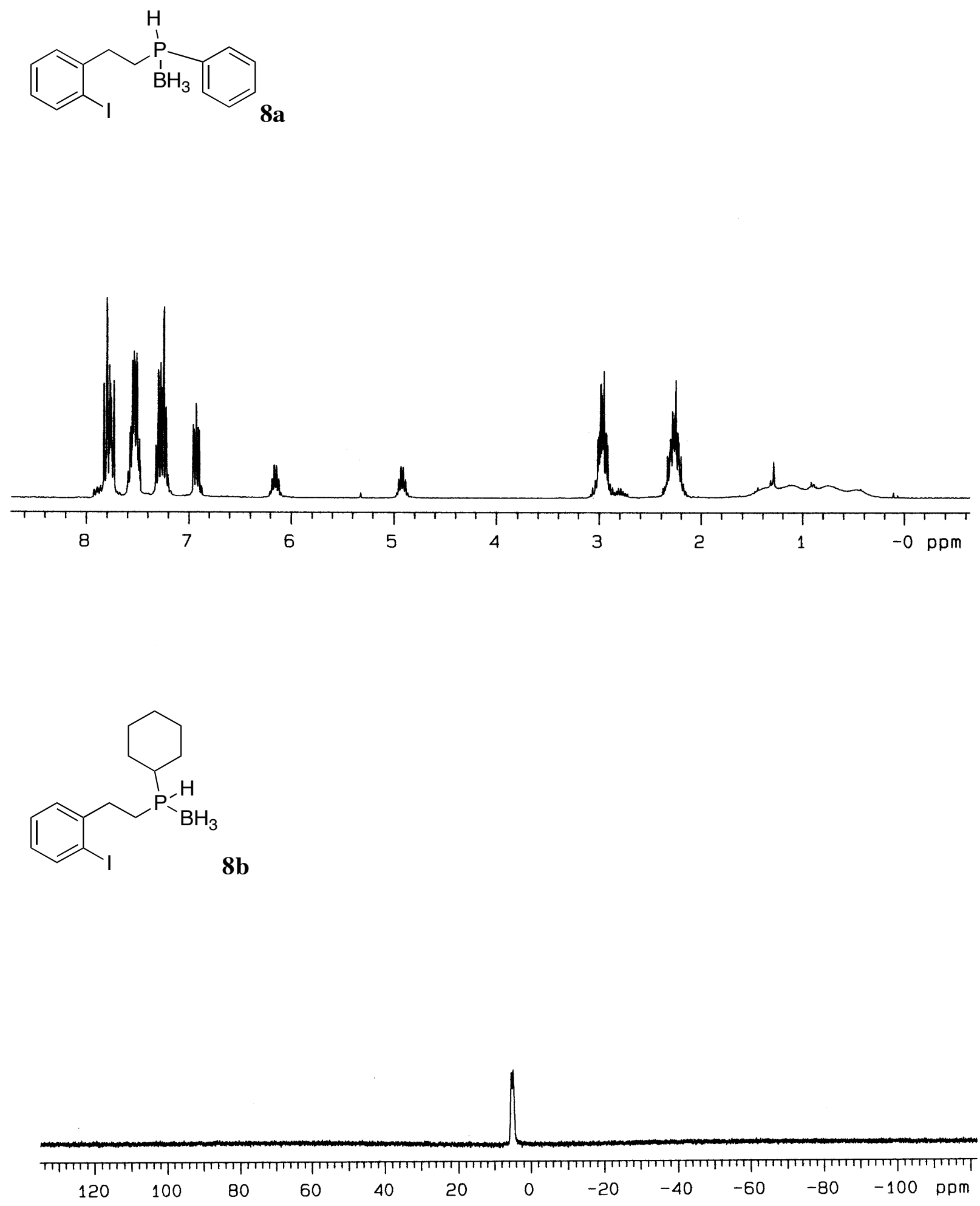

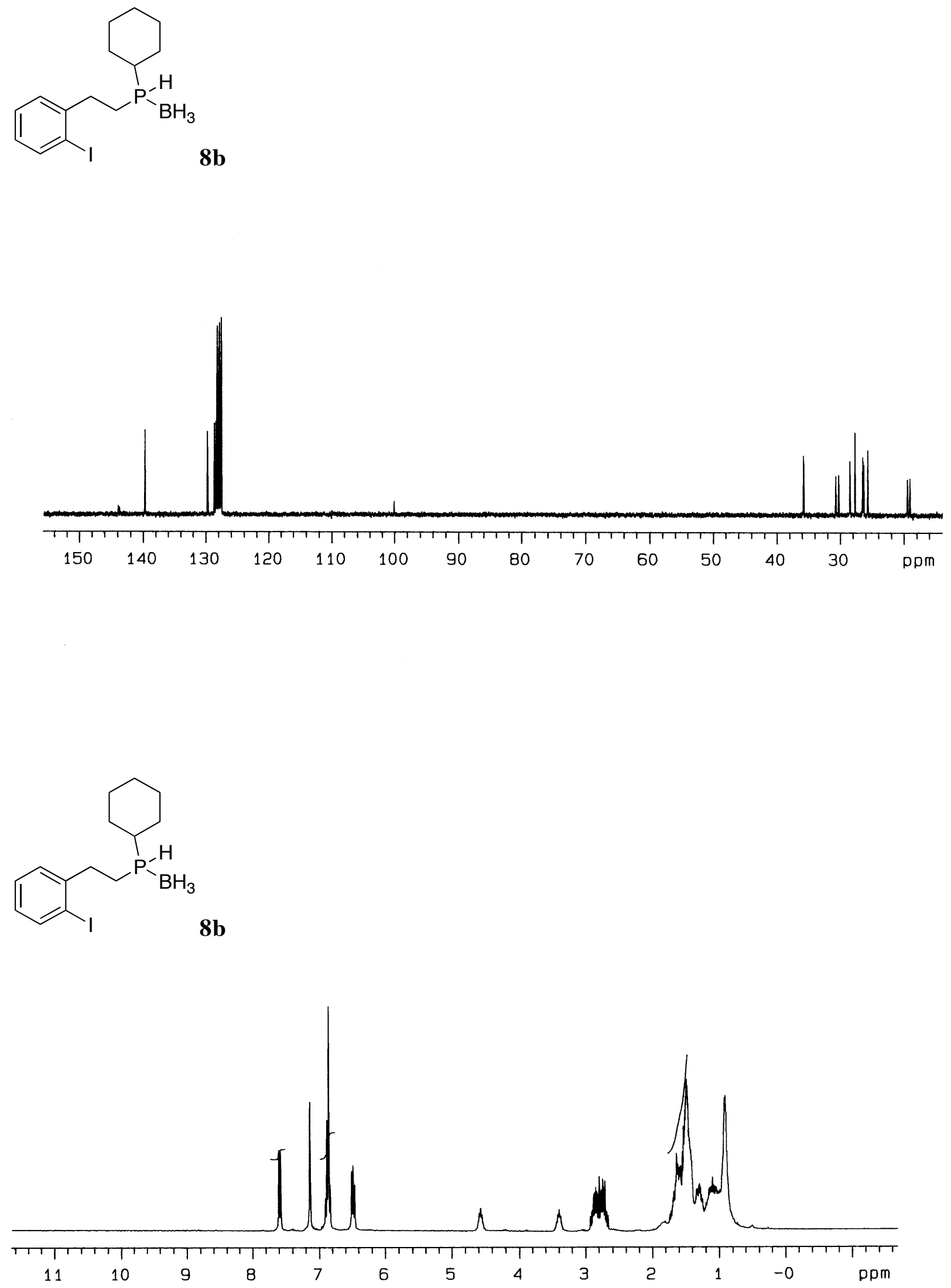

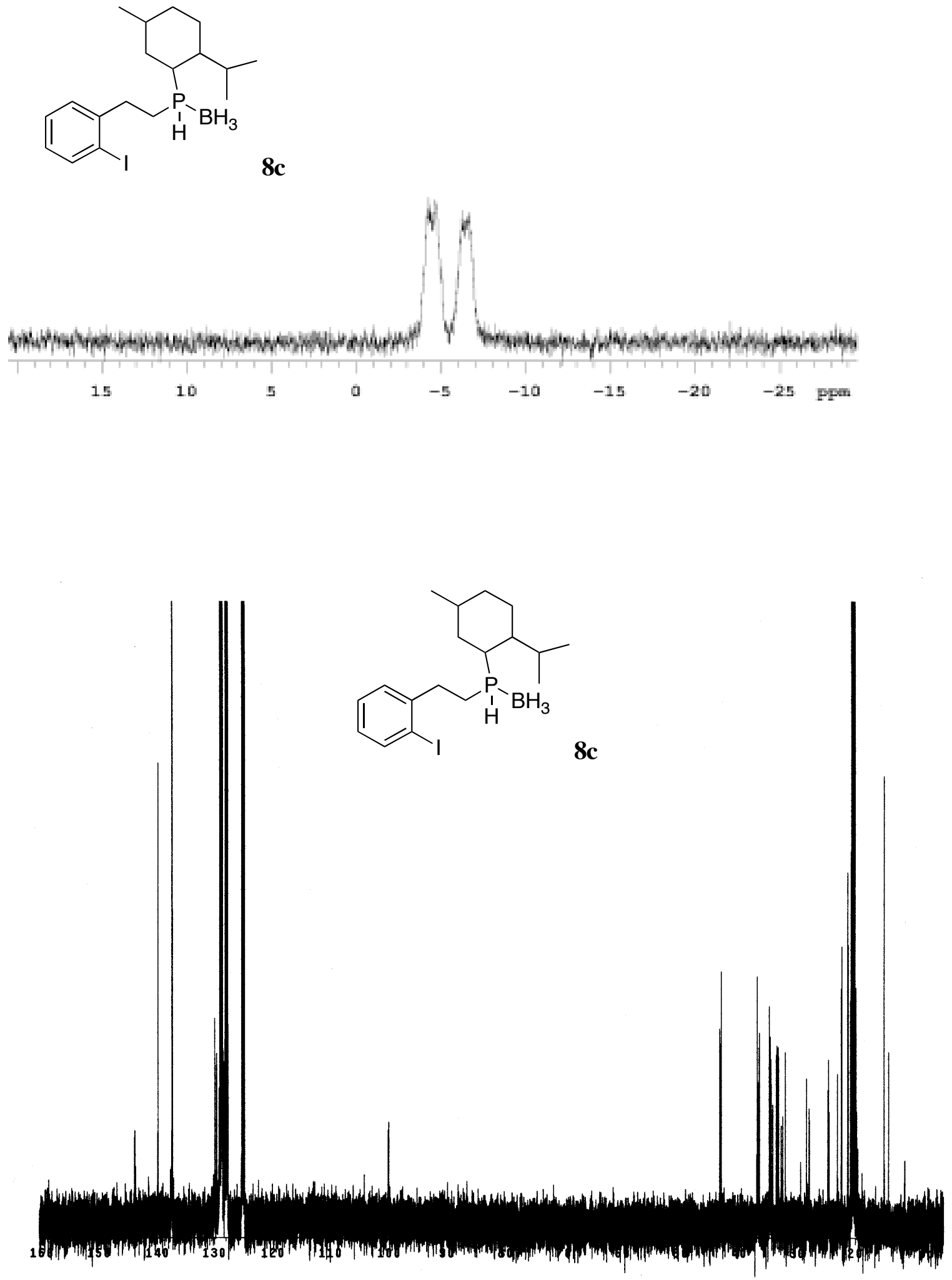

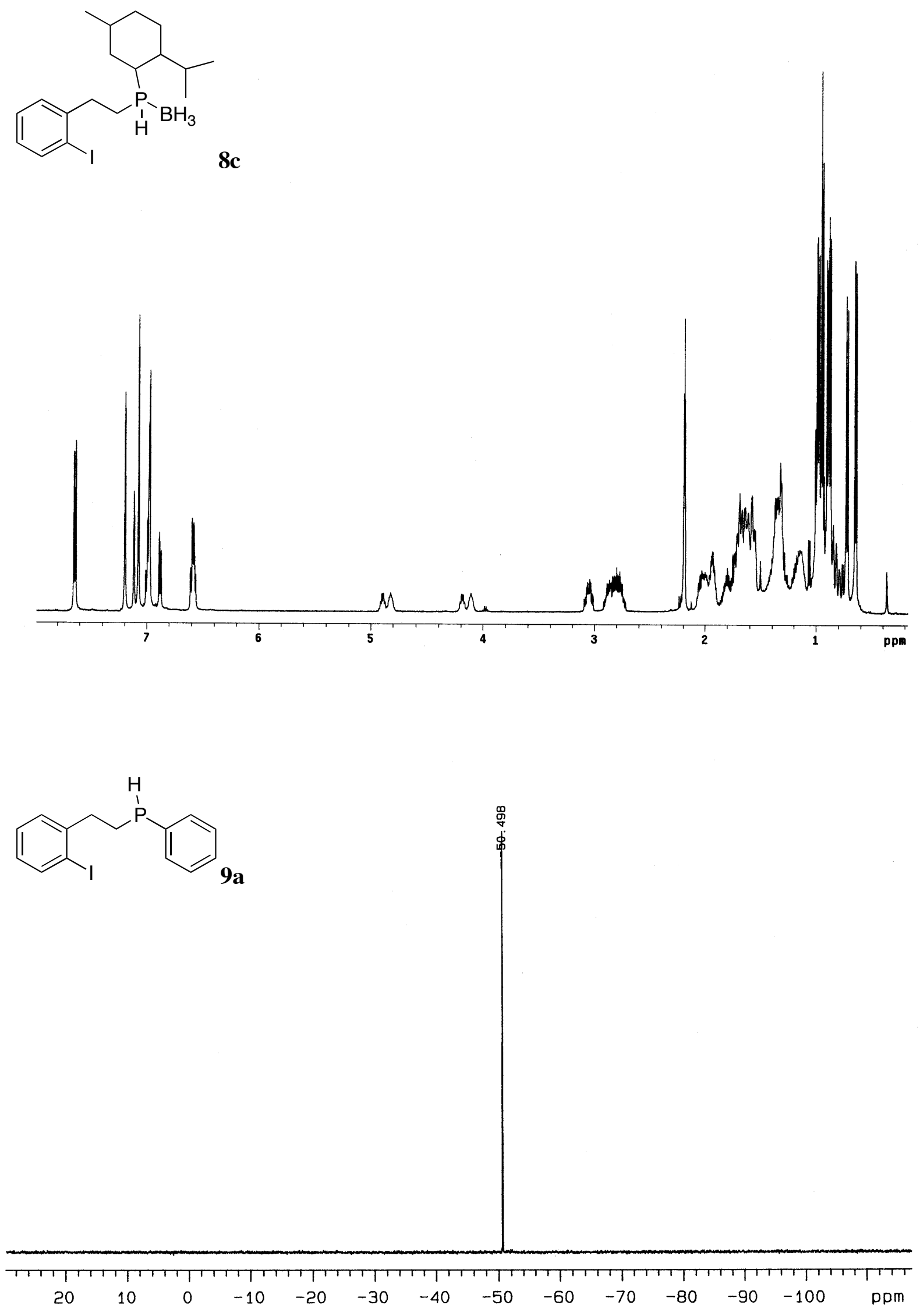

S35 

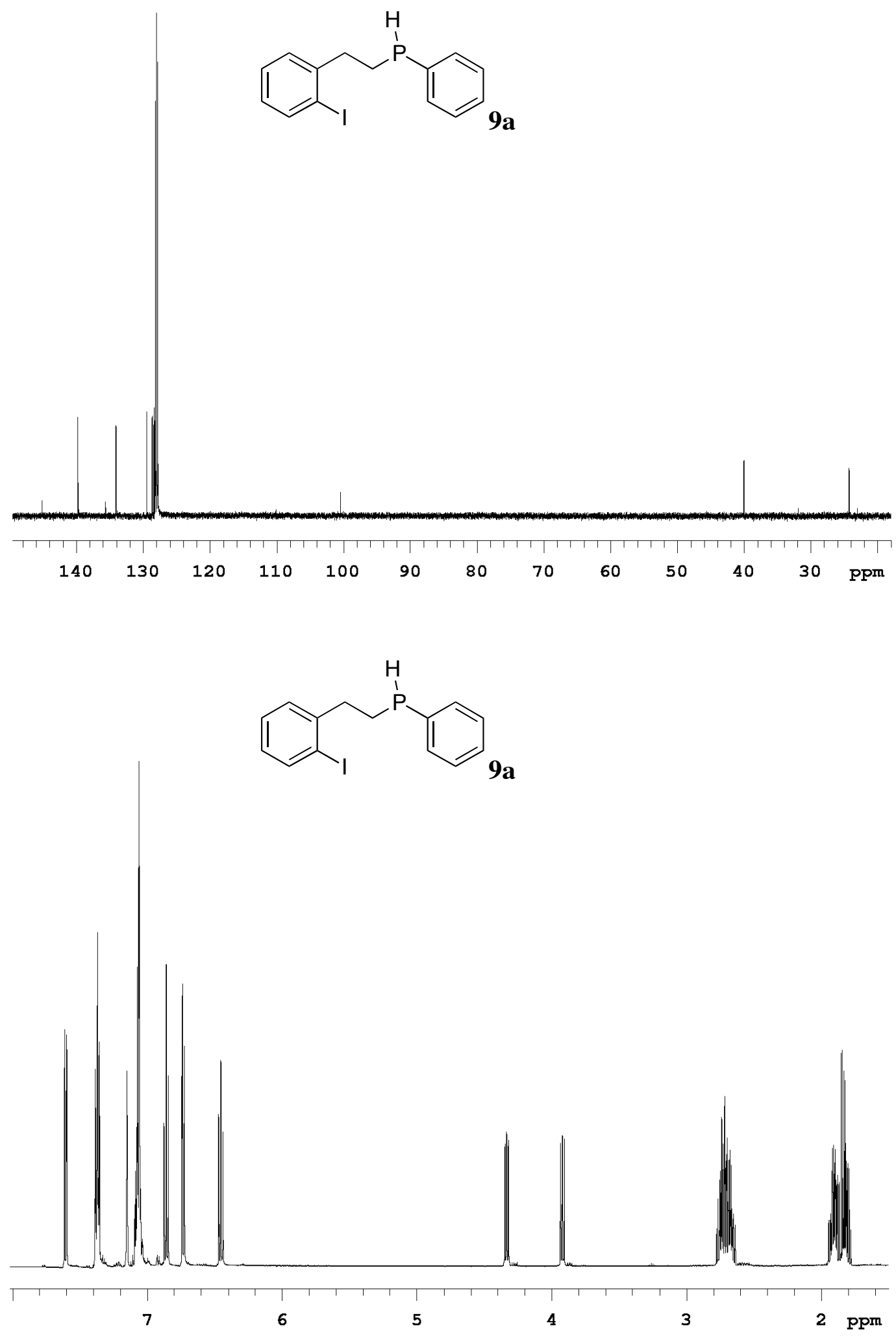

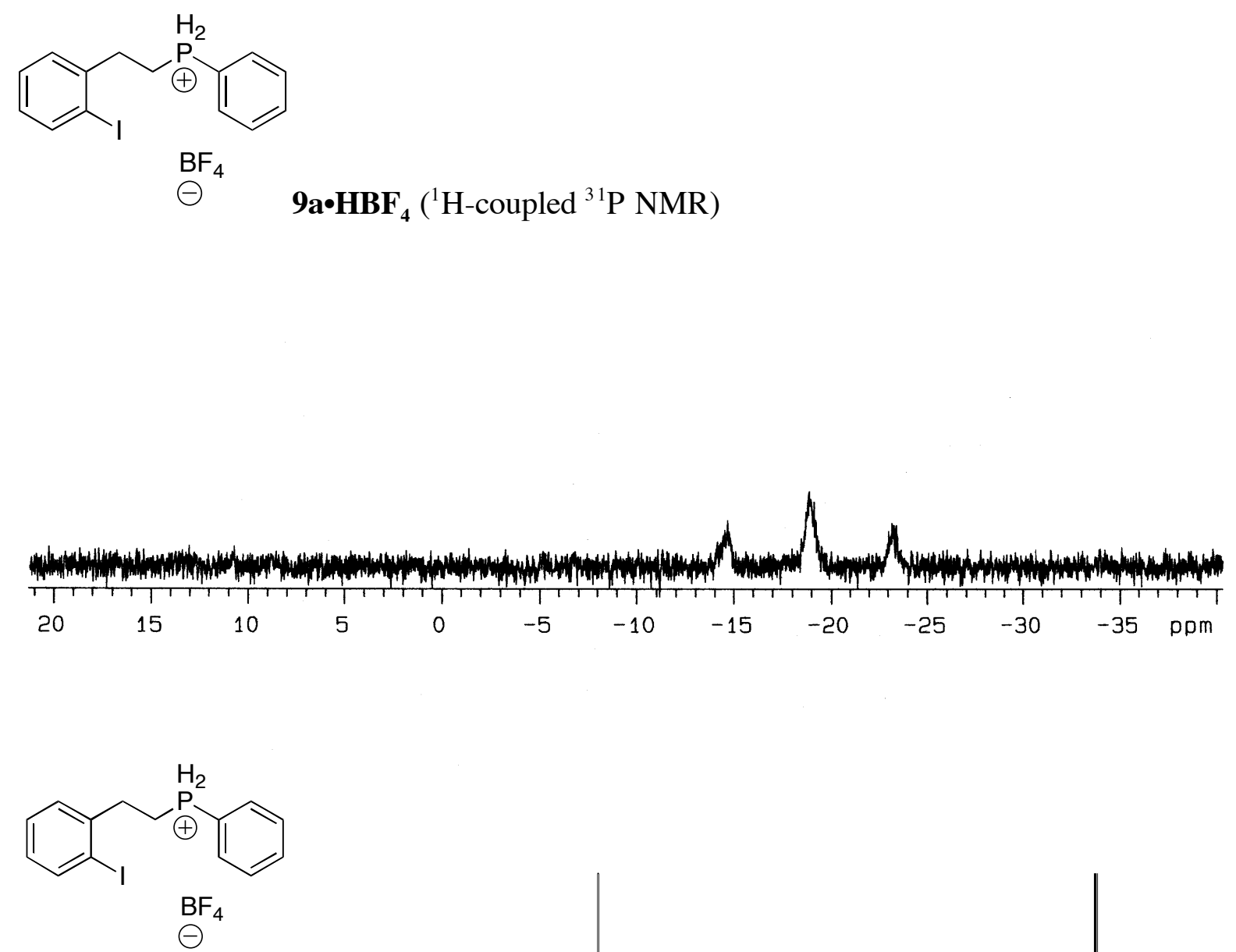

$9 a \cdot \mathrm{HBF}_{4}$

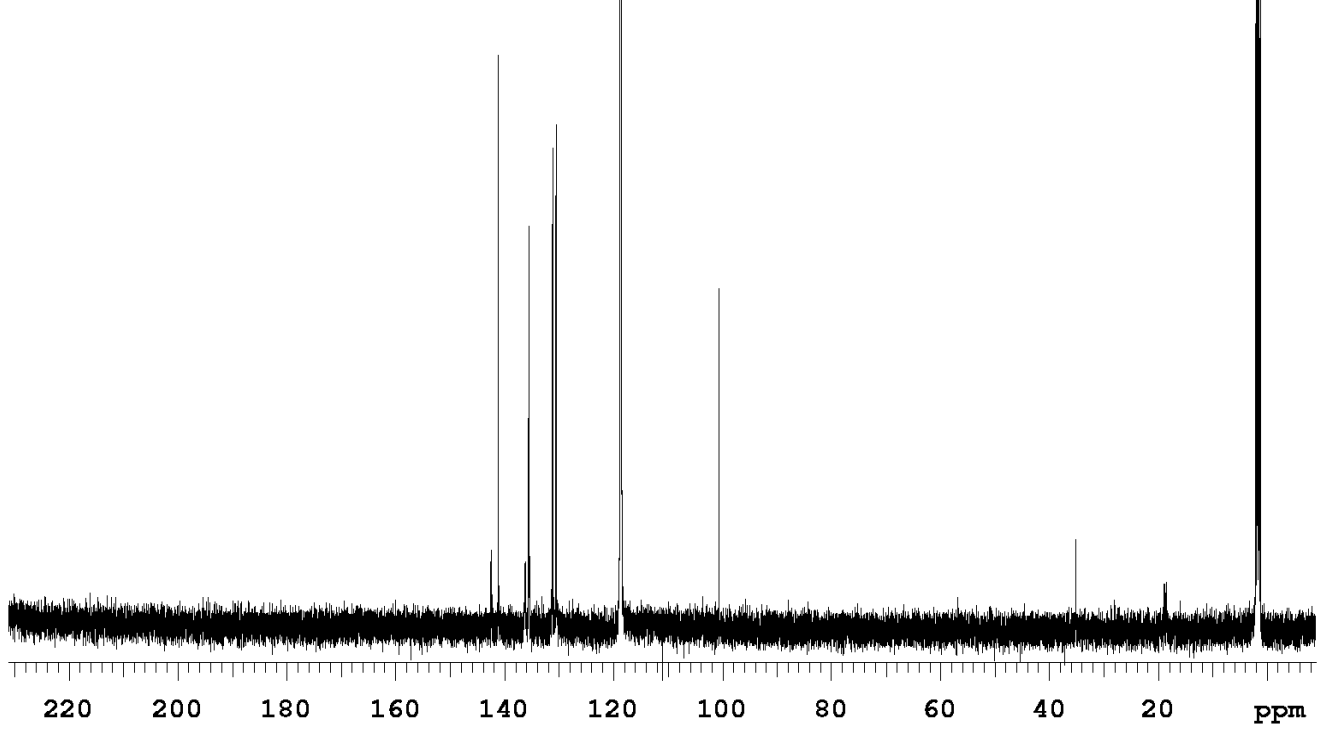



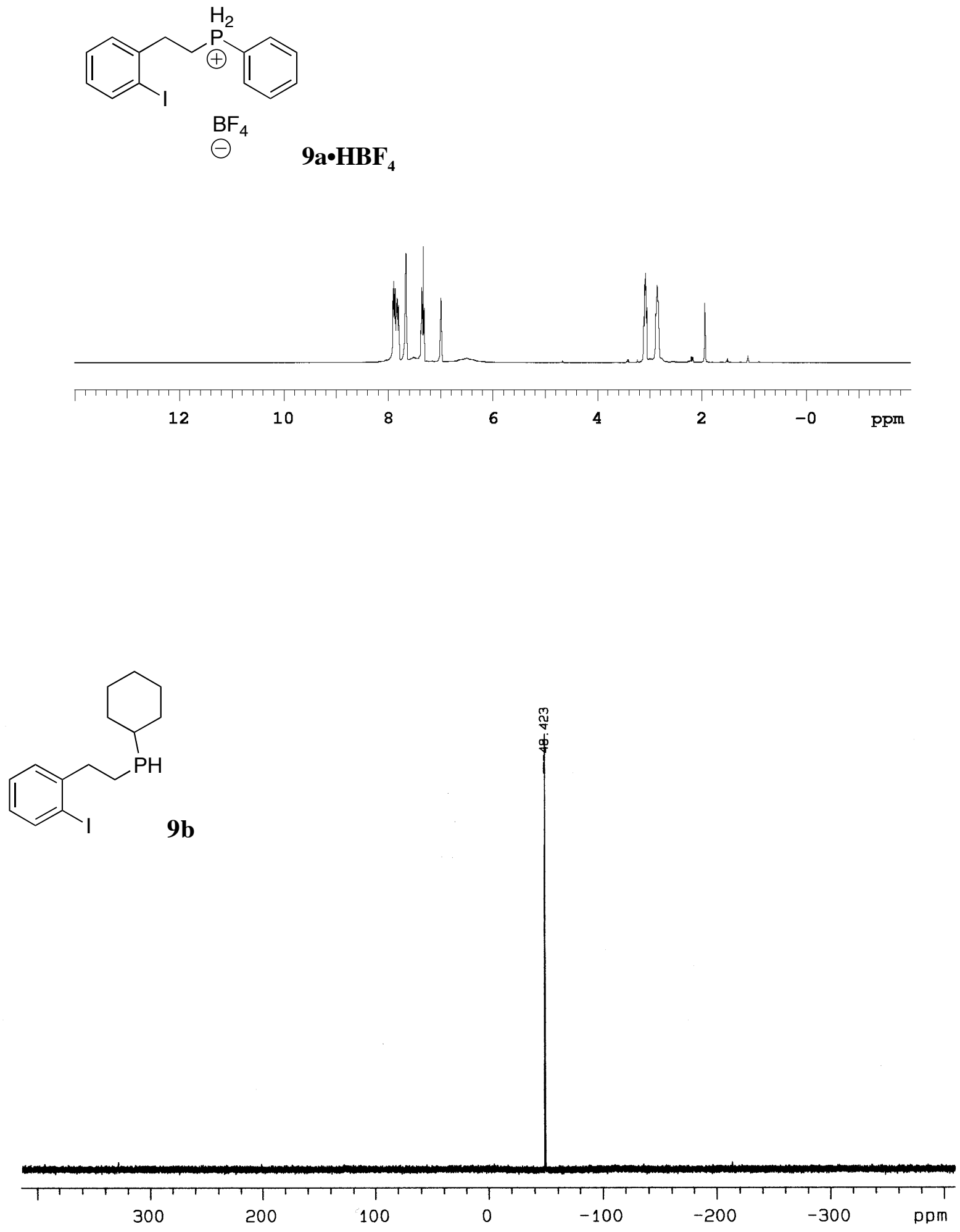

S38 

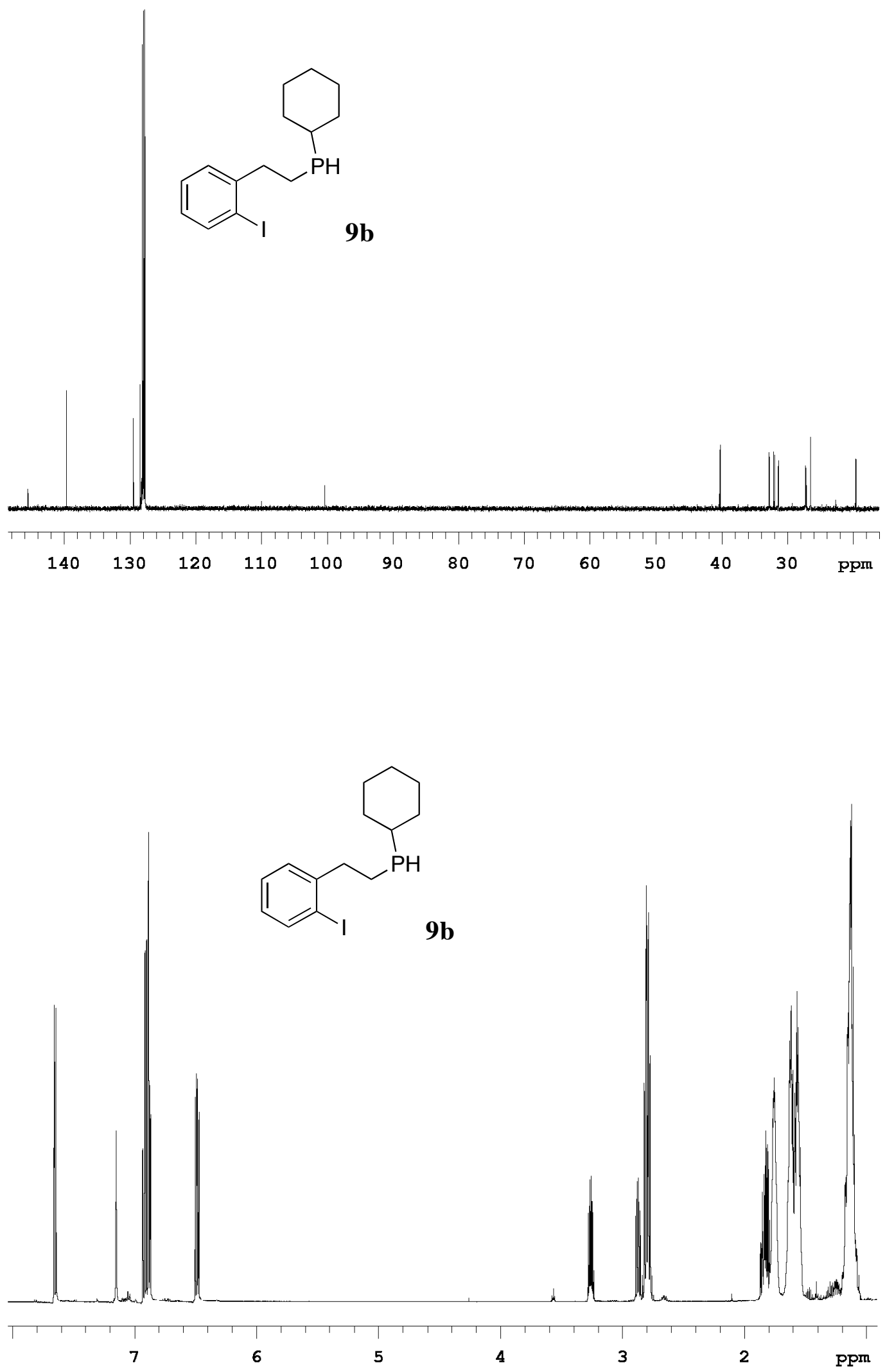

S39 

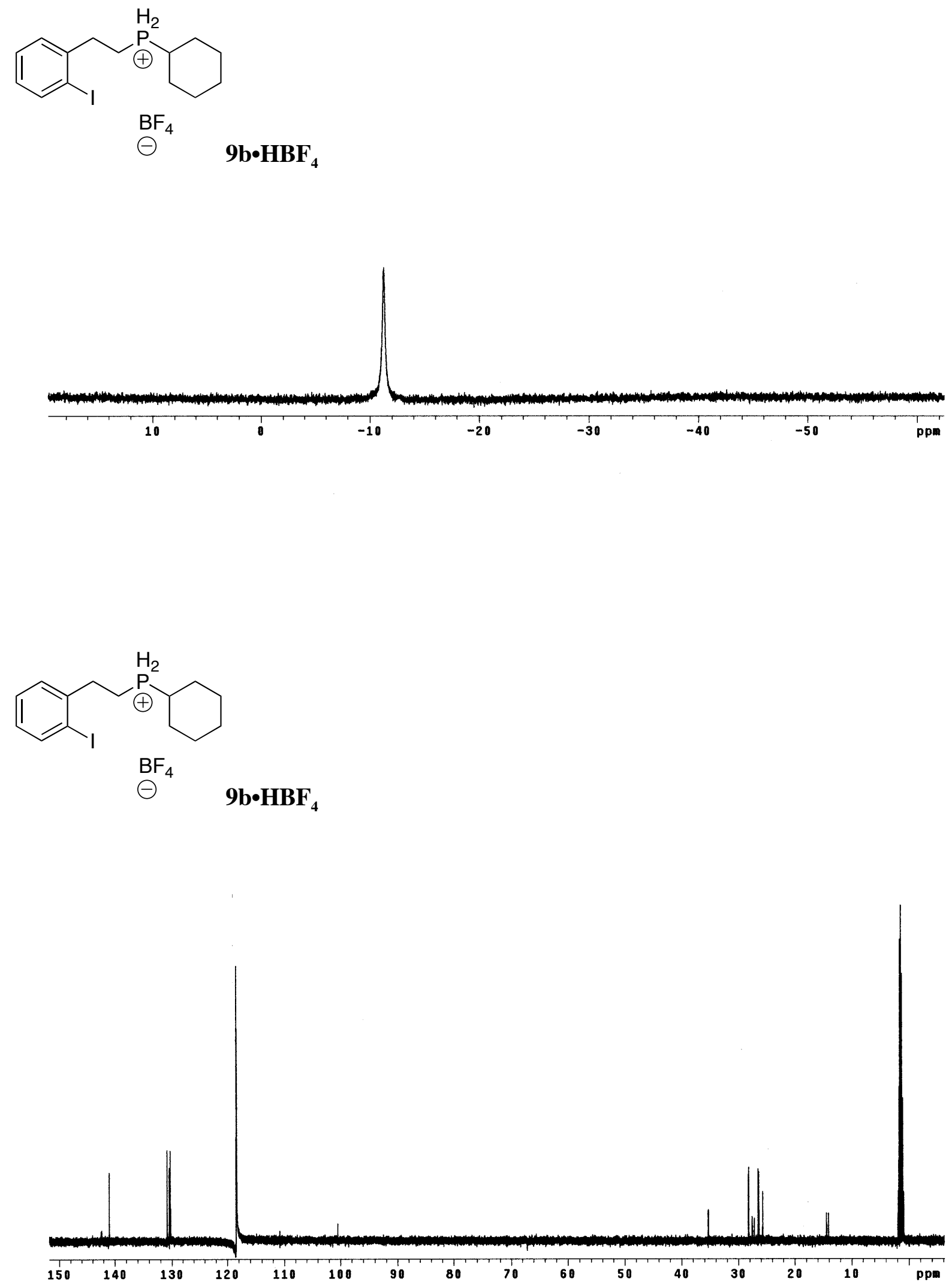

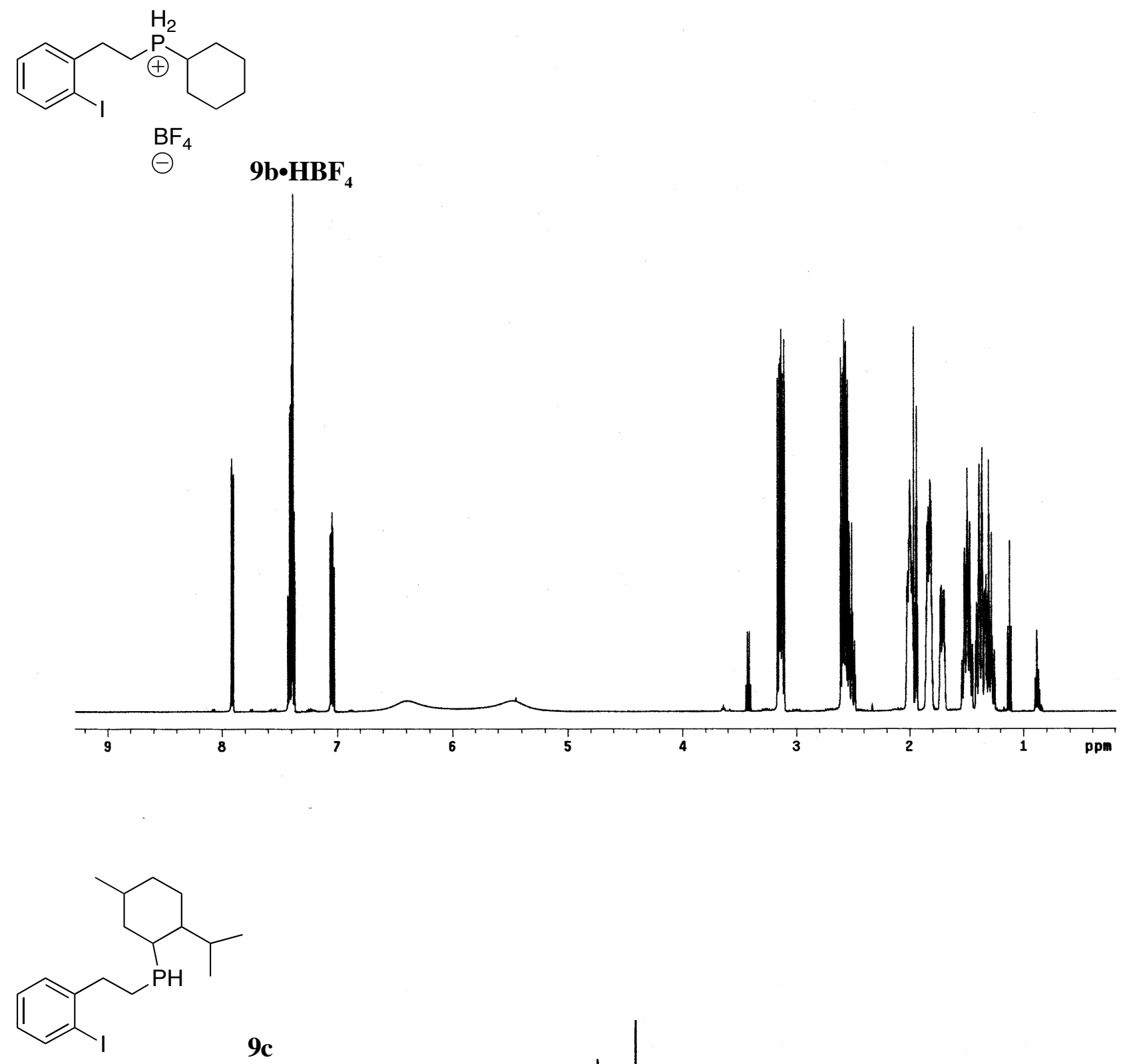


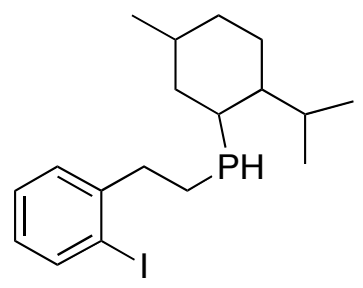

9c
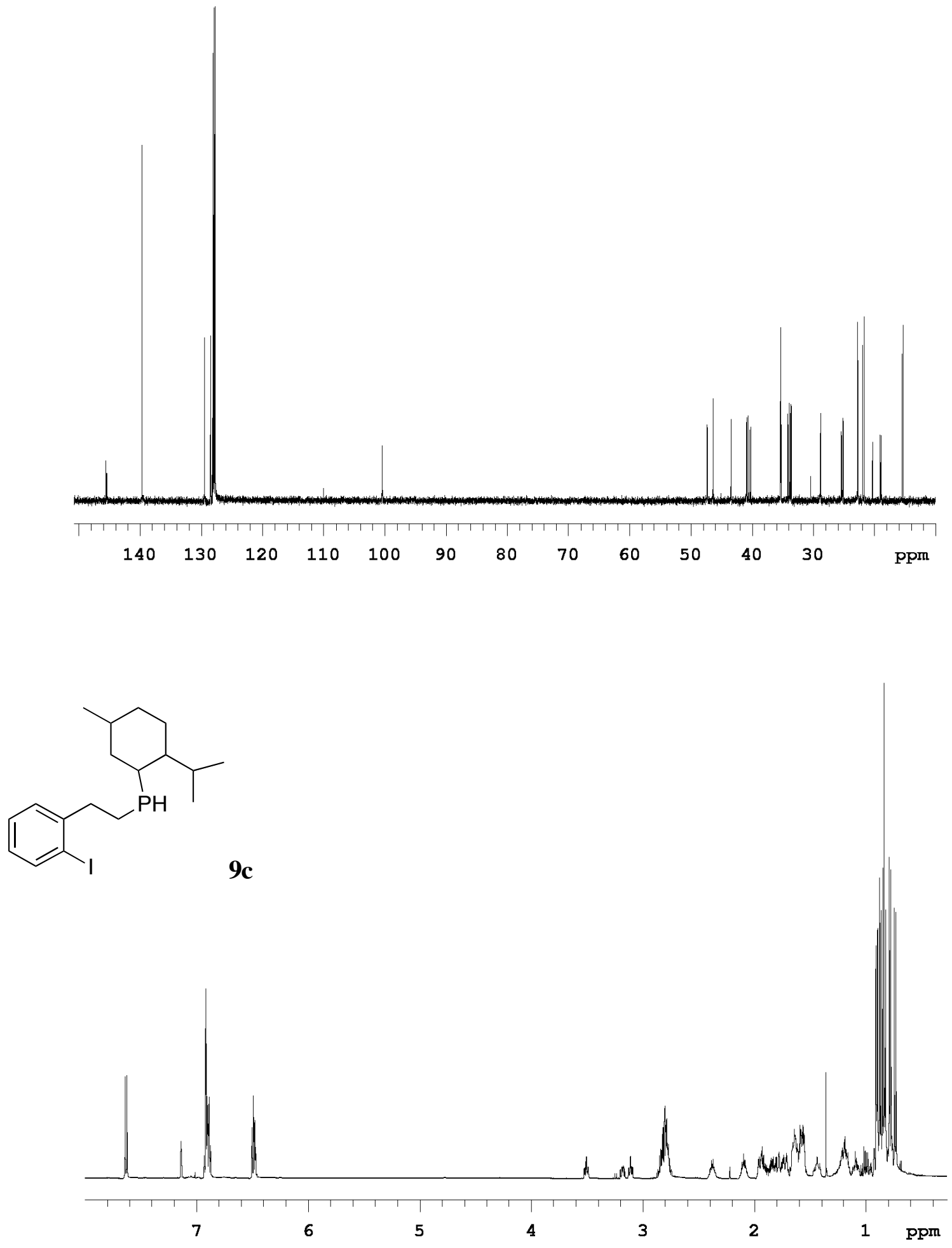

S42 


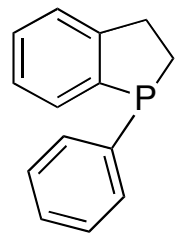

10a
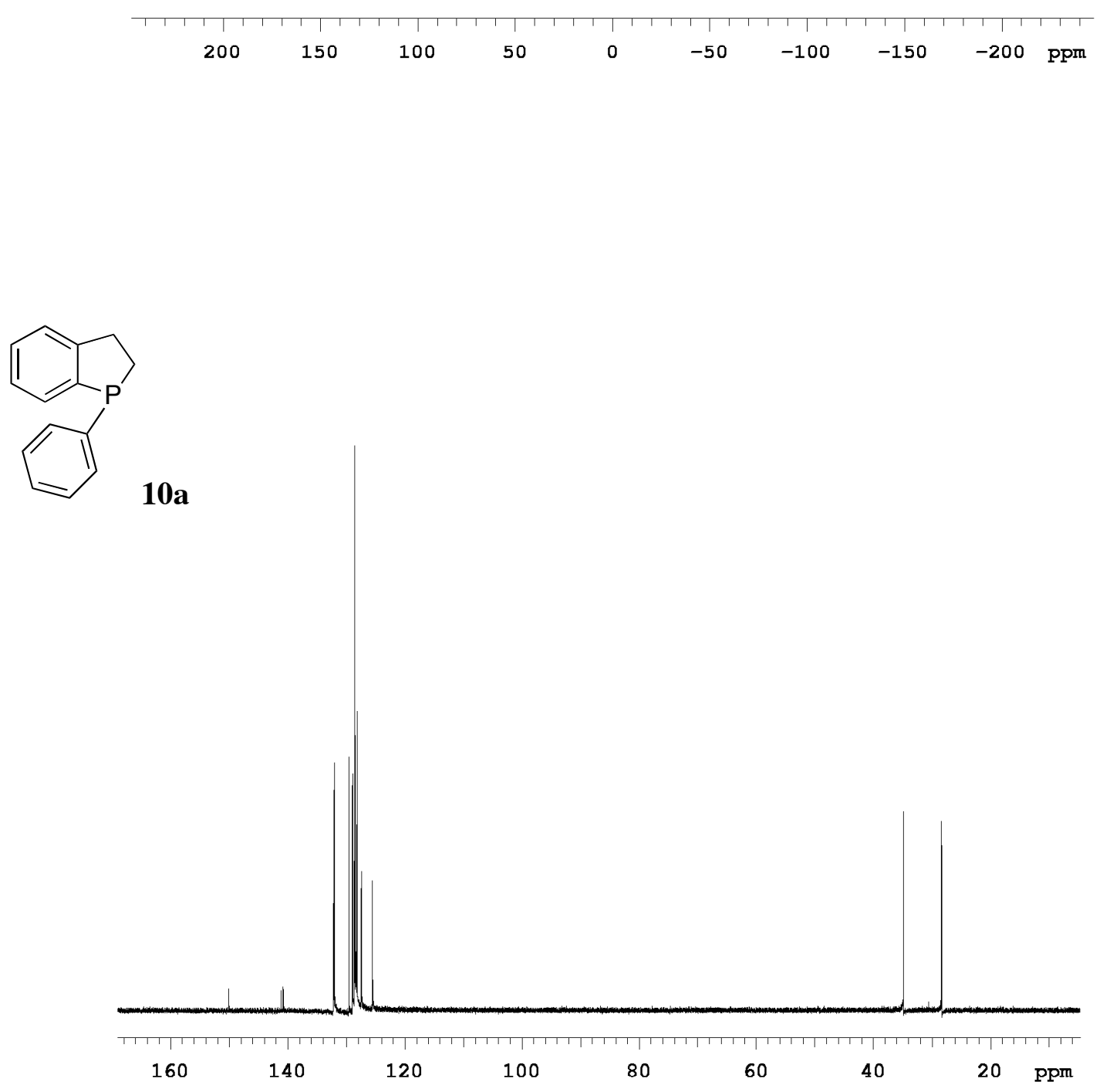

S43 


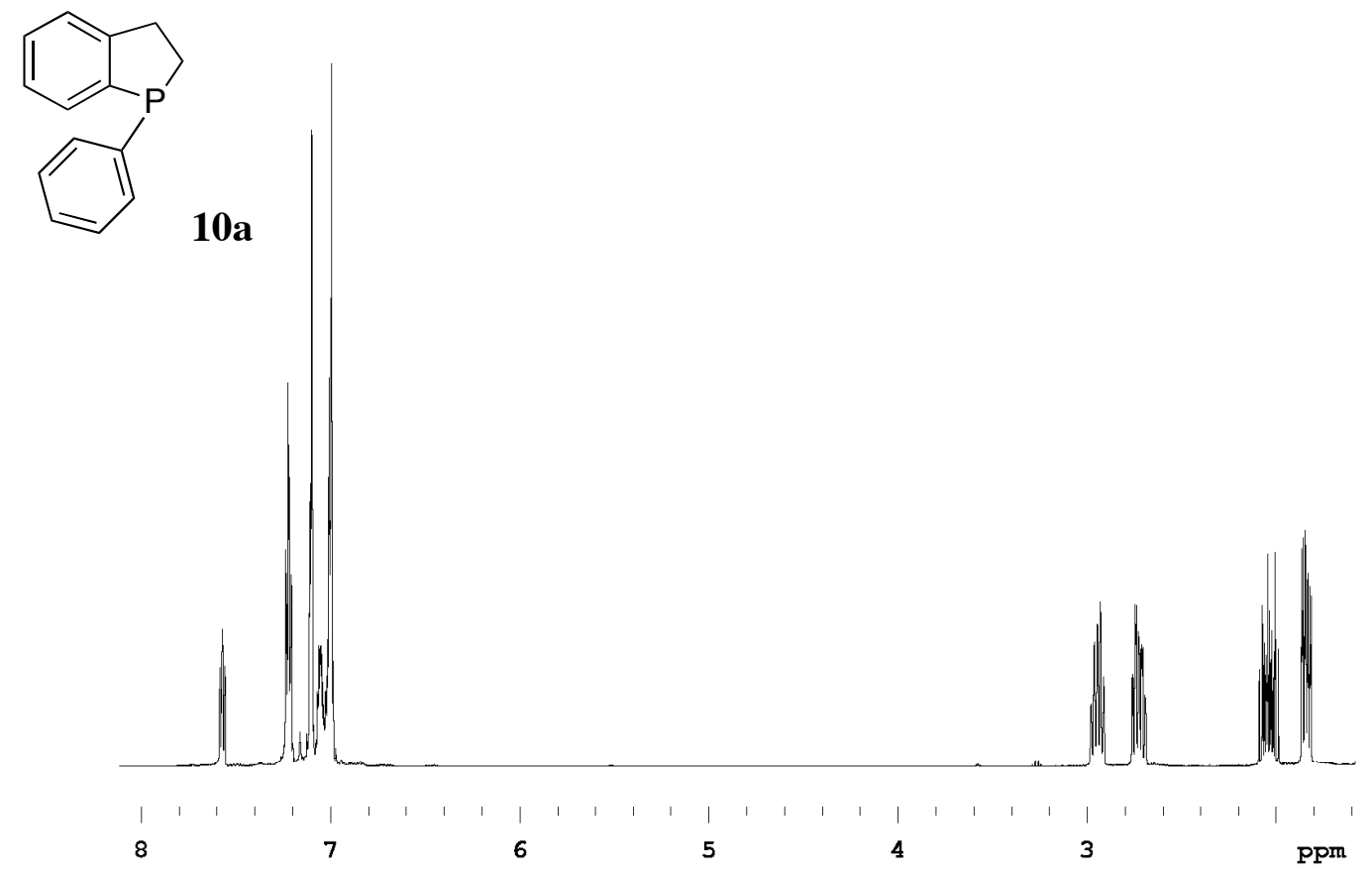

$\overbrace{10 b}$ 

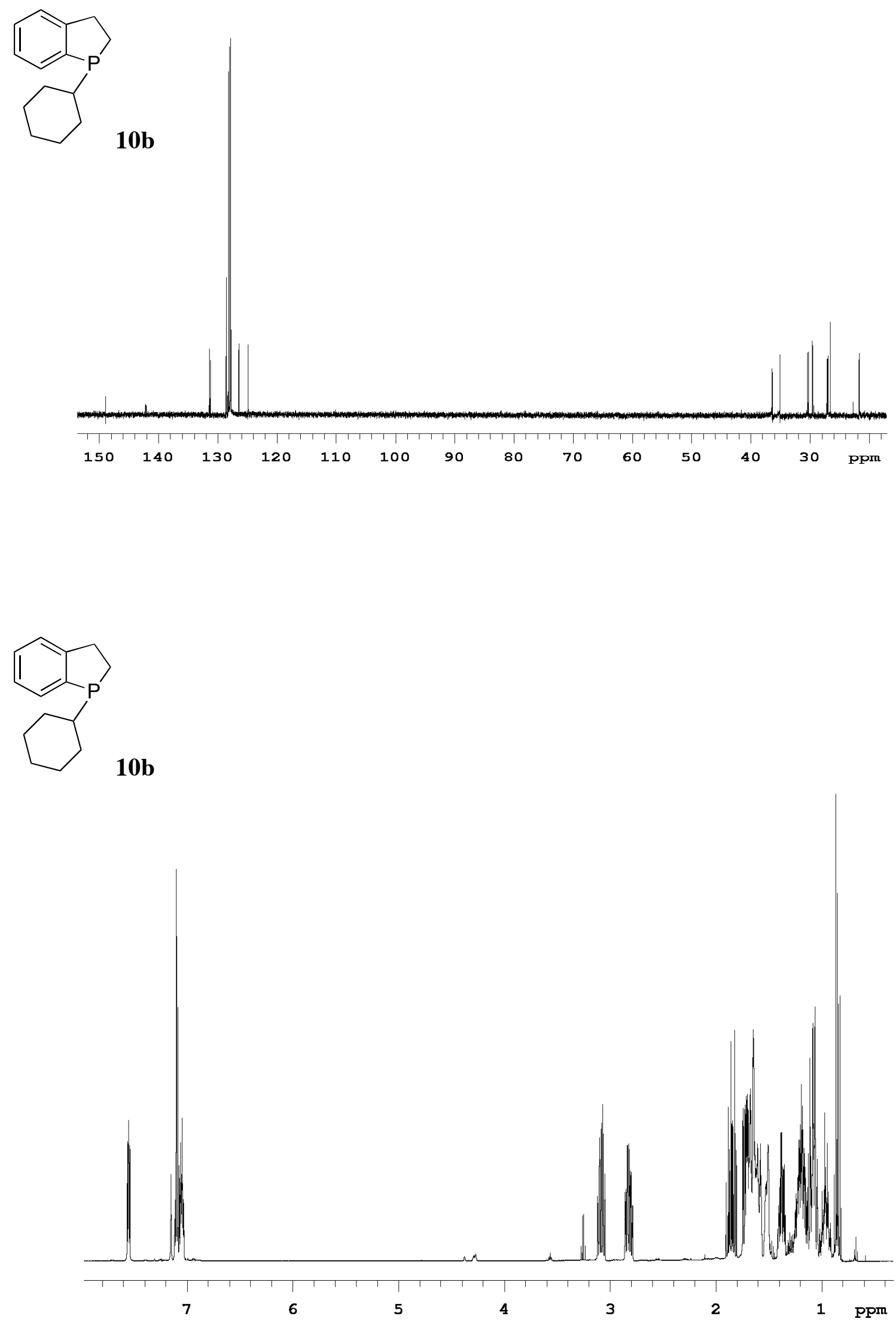

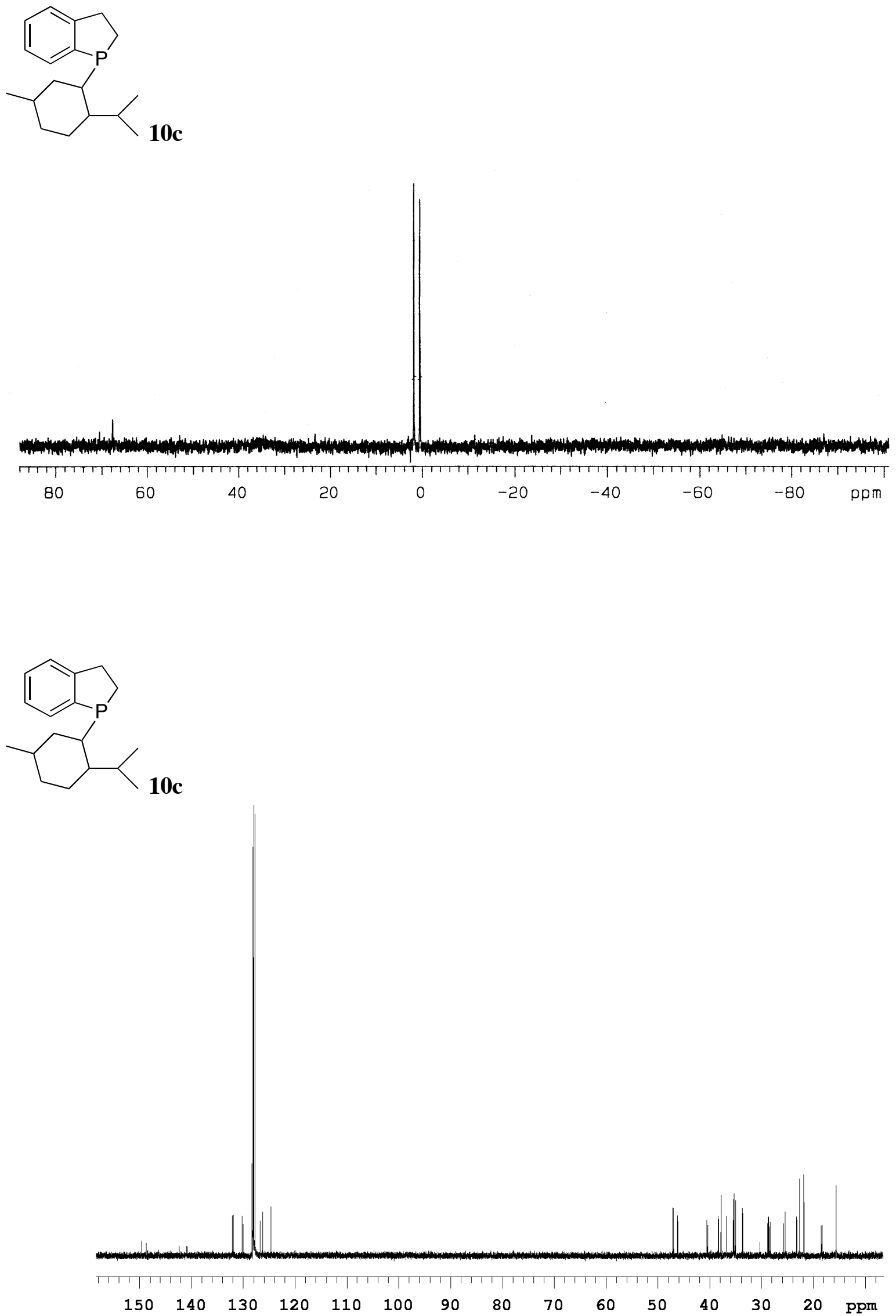

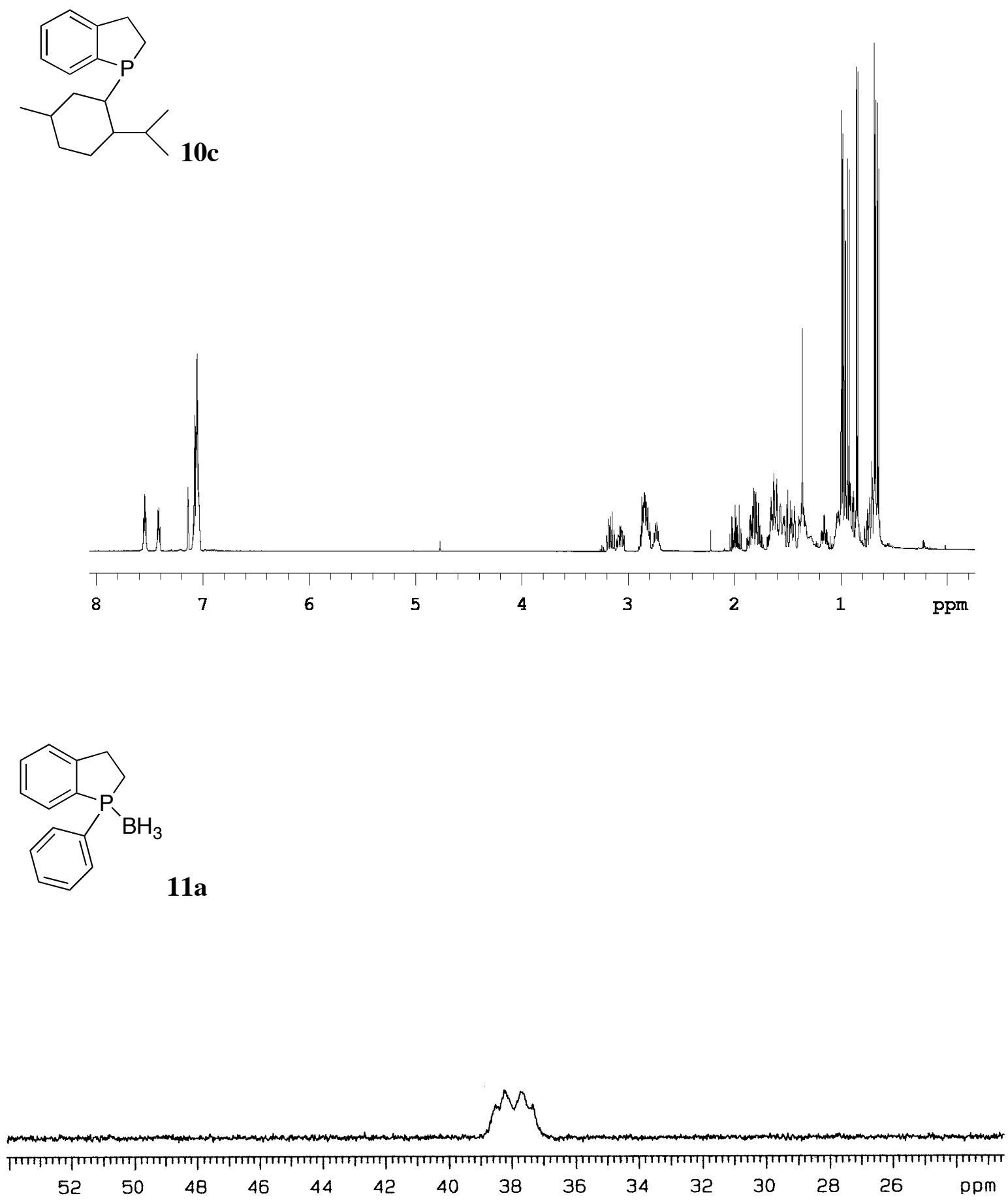
<smiles>[B][PH]1(c2ccccc2)CCc2ccccc21</smiles>
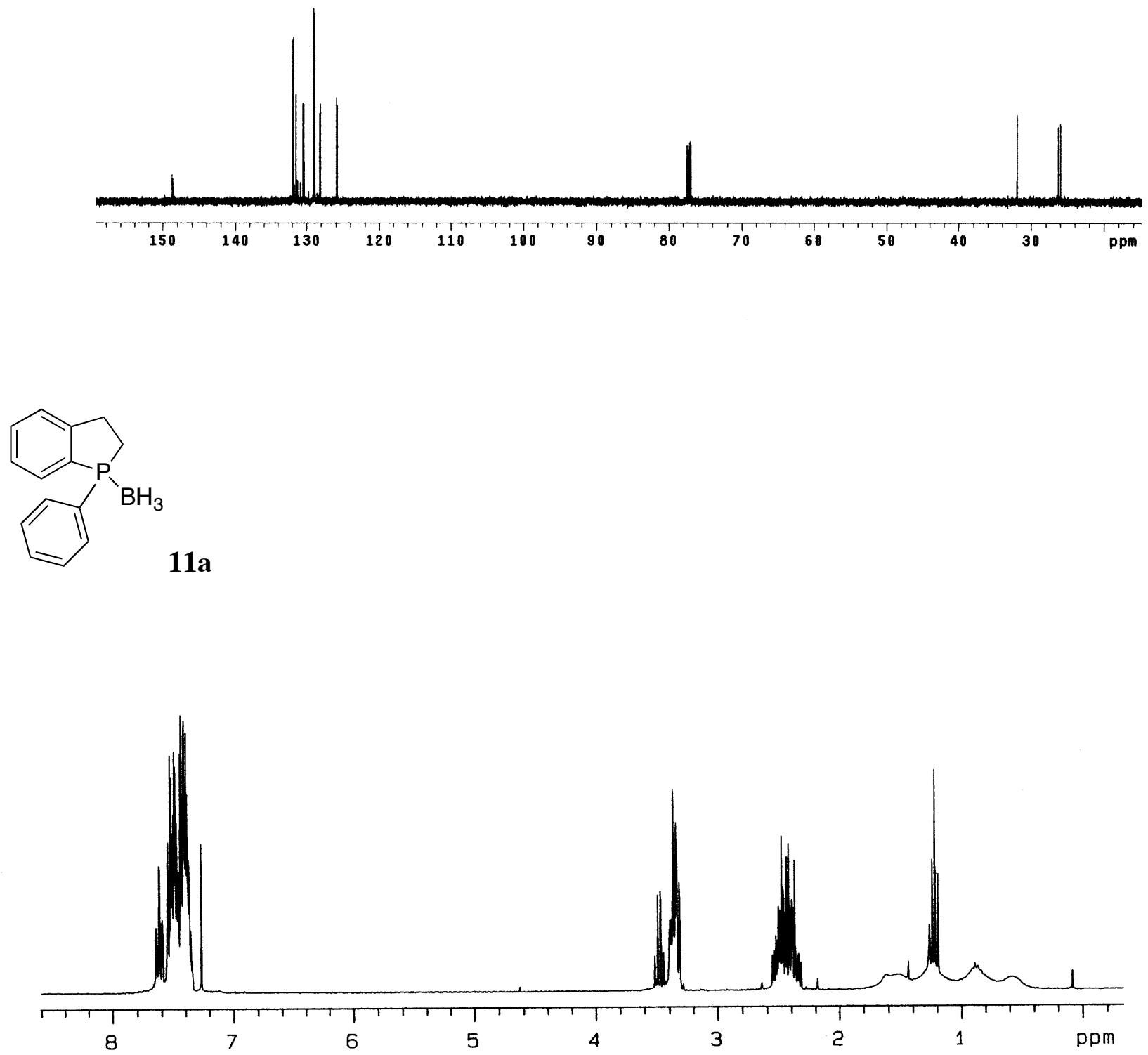

S48 

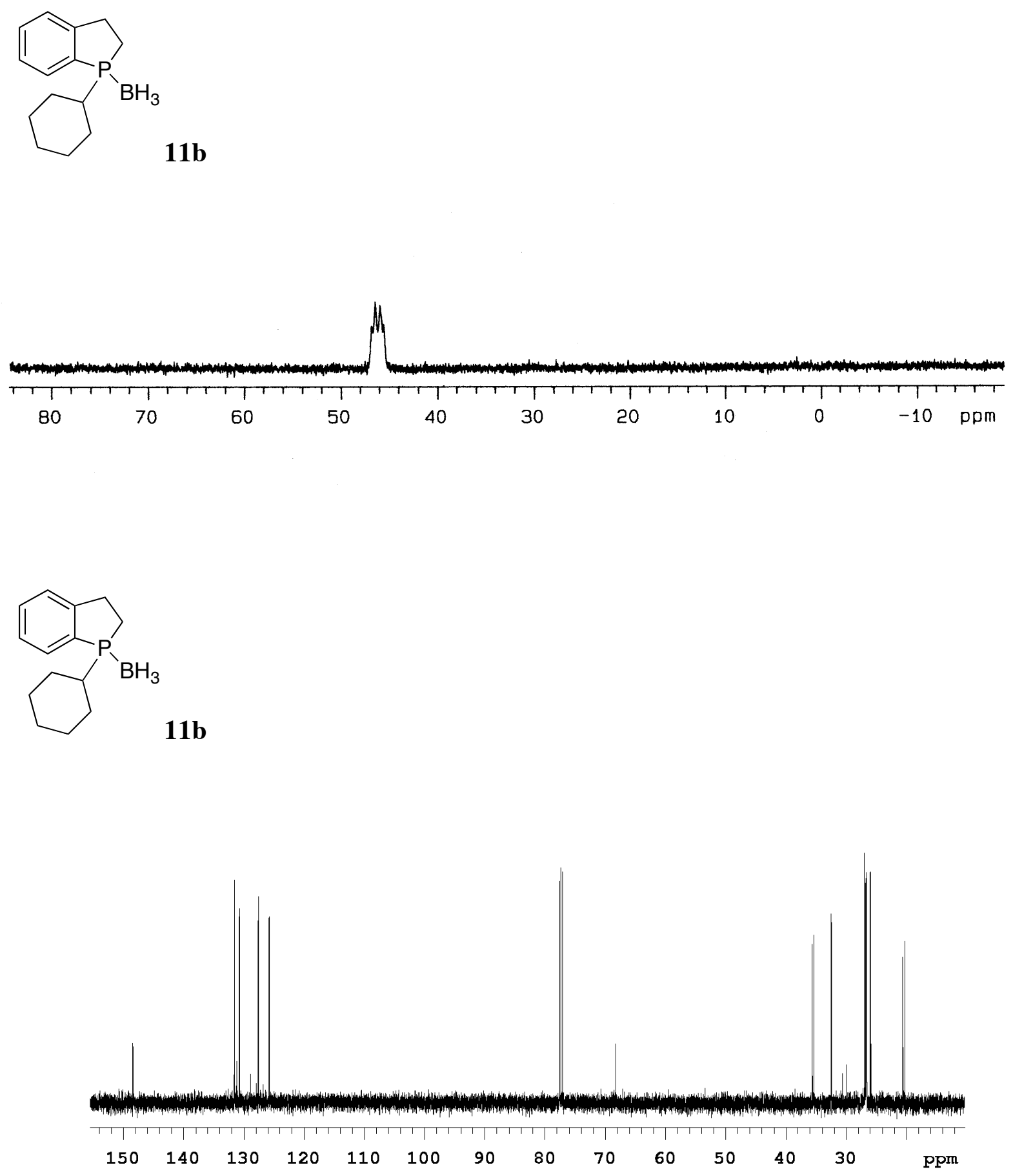

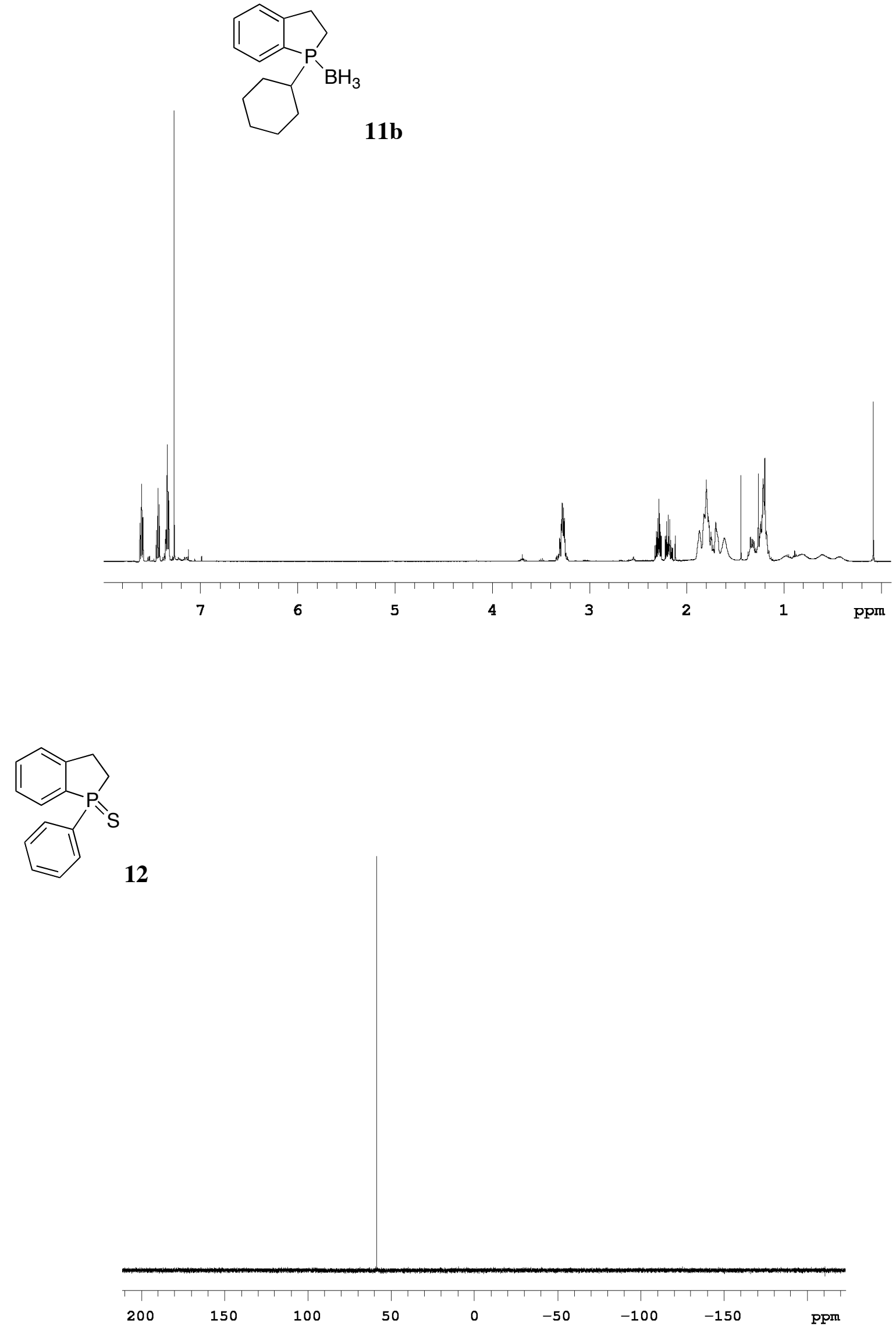

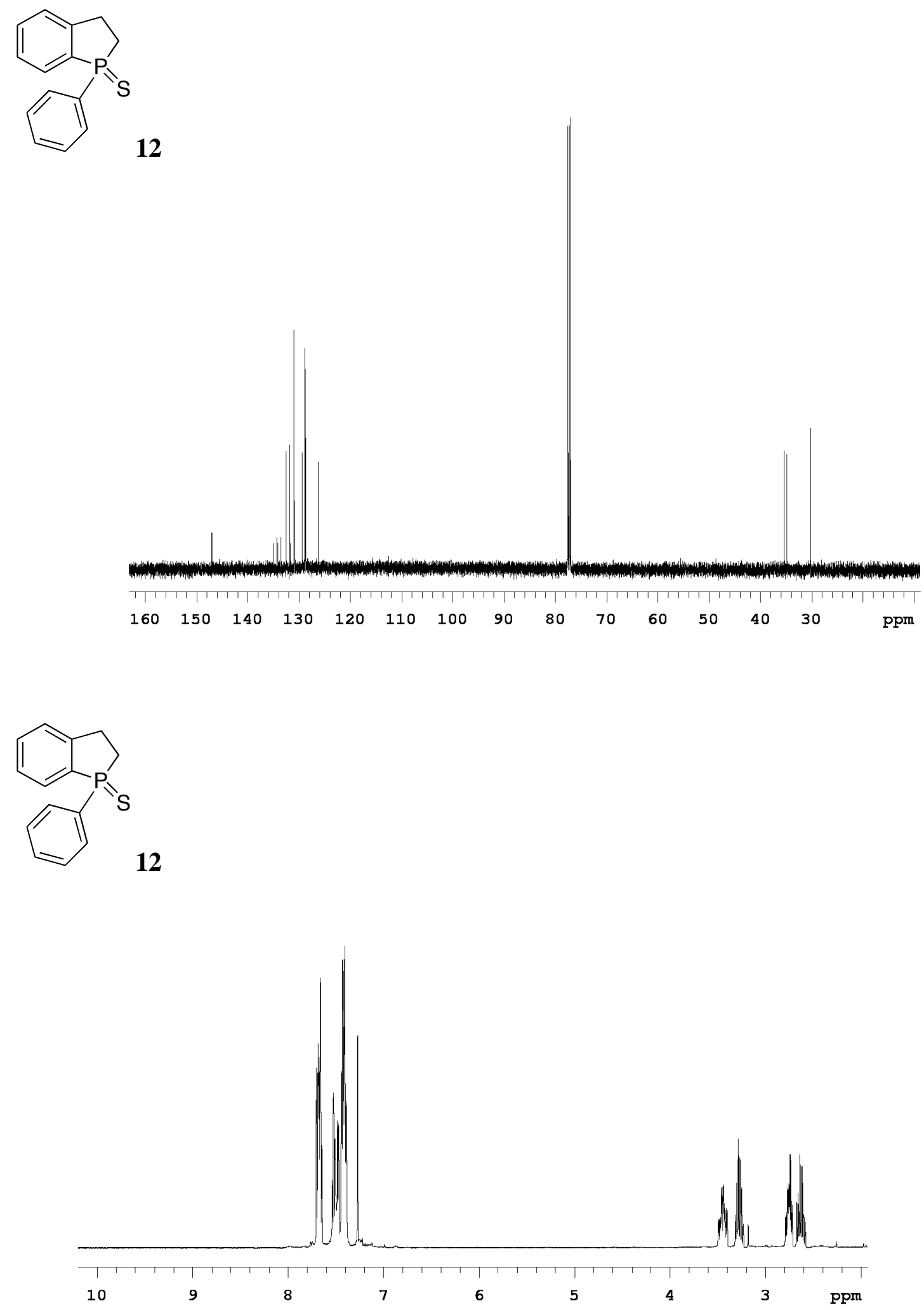
<smiles>[B][PH]1(c2ccccc2)c2ccccc2CC1[CH]</smiles>

13

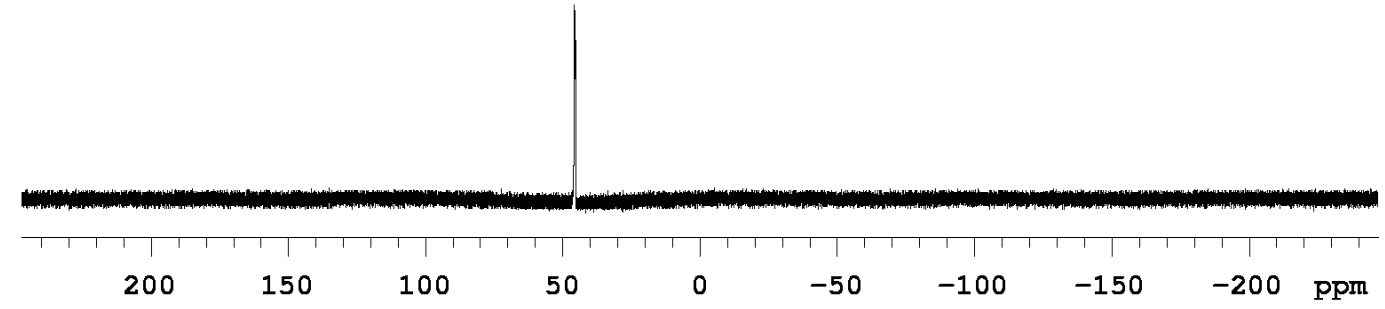<smiles>[R5][PH]1(c2ccccc2)c2ccccc2CC1C</smiles>

13

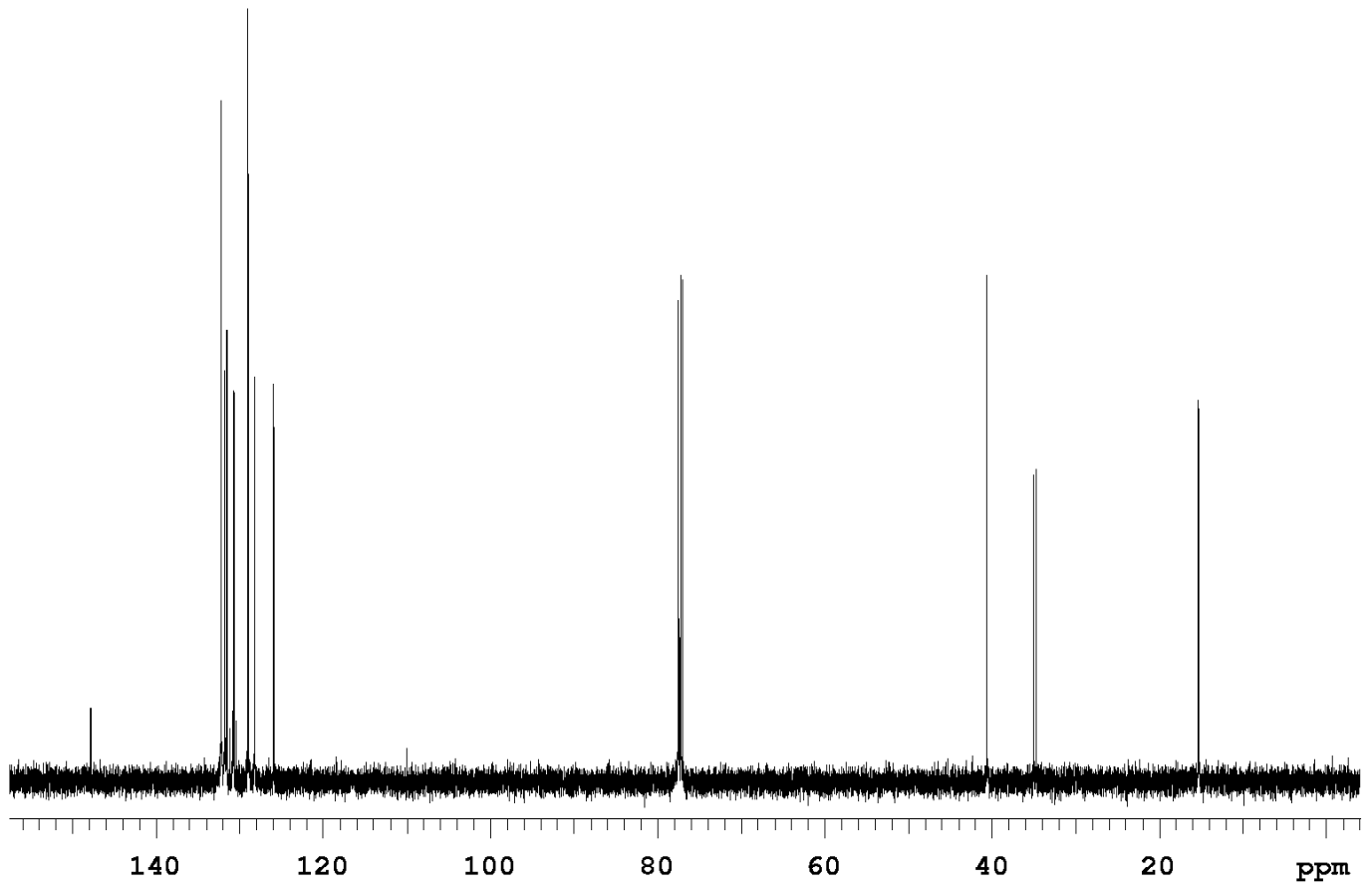




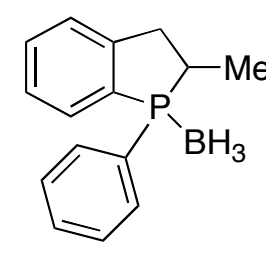

13

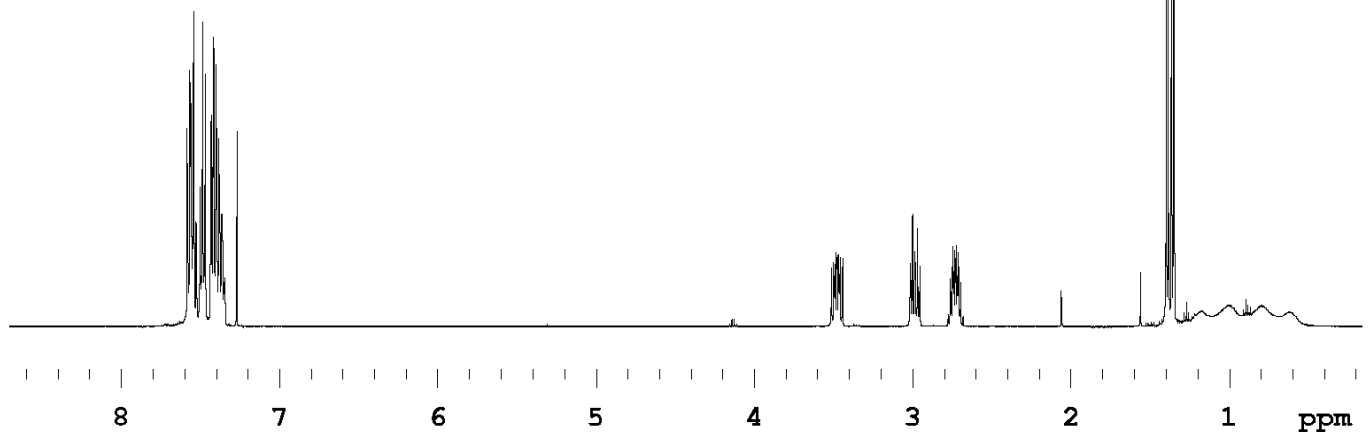




\section{References}

1. Pangborn, A. B.; Giardello, M. A.; Grubbs, R. H.; Rosen, R. K.; Timmers, F. J. Organometallics 1996, $15,1518-1520$.

2. Brunel, J. M.; Faure, B.; Maffei, M. Coord. Chem. Rev. 1998, 178-180, 665-698.

3. Ripa, L.; Hallberg, A. J. Org. Chem. 1996, 61, 7147-7155.

4. Bourumeau, K.; Gaumont, A.-C.; Denis, J.-M. J. Organomet. Chem. 1997, 529, 205-213.

5. Blank, N. F.; McBroom, K. C.; Glueck, D. S.; Kassel, W. S.; Rheingold, A. L. Organometallics 2006, 25, 1742-1748.

6. Brunker, T. J.; Blank, N. F.; Moncarz, J. R.; Scriban, C.; Anderson, B. J.; Glueck, D. S.; Zakharov, L. N.; Golen, J. A.; Sommer, R. D.; Incarvito, C. D.; Rheingold, A. L. Organometallics 2005, 24, 2730-2746.

7. Rettig, M. F.; Maitlis, P. M. Inorg. Synth. 1990, 28, 110-113.

8. Roberts, N. K.; Wild, S. B. J. Am. Chem. Soc. 1979, 101, 6254-6260.

9. Sayalero, S.; Pericas, M. A. Synlett 2006, 2585-2588.

10. The ligands were commercially available, except for the ferrocenyl-phospholane 5-Fc (see ref. 16 of the text for its synthesis, and Boulton, L. T.; Lennon, I. C.; McCague, R. Org. Biomol. Chem. 2003, 1, 1094-1096 for the name.)

11. The large ${ }^{31} \mathrm{P}$ NMR chemical shift difference between the diastereomers of $\mathbf{1 3}$ is consistent with literature precedent. See: Quin, L. D., The Heterocyclic Chemistry of Phosphorus: Systems Based on the Phosphorus-Carbon Bond. Wiley-Interscience: New York, 1981, Chapter 5. 